\title{
IMPACT OF CST ON THE RHEOLOGICAL CHARACTERISTICS OF DWPF MELTER FEED (U)
}

E. K. Hansen

D. C. Koopman

P. R. Monson

Westinghouse Savannah River Company

Savannah River Site

Aiken, SC 29808

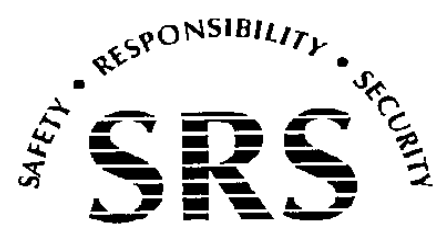

PREPARED FOR THE U.S. DEPARTMENT OF ENERGY UNDER CONTRACT NO. DE-AC09-96SR18500 
This document was prepared in conjunction with work accomplished under Contract No.

DE-AC09-96SR18500 with the U.S. Department of Energy.

\section{DISCLAIMER}

This report was prepared as an account of work sponsored by an agency of the United States Government. Neither the United States Government nor any agency thereof, nor any of their employees, makes any warranty, express or implied, or assumes any legal liability or responsibility for the accuracy, completeness, or usefulness of any information, apparatus, product or process disclosed, or represents that its use would not infringe privately owned rights. Reference herein to any specific commercial product, process or service by trade name, trademark, manufacturer, or otherwise does not necessarily constitute or imply its endorsement, recommendation, or favoring by the United States Government or any agency

thereof. The views and opinions of authors expressed herein do not necessarily state or reflect those of the United States Government or any agency thereof.

This report has been reproduced directly from the best available copy.

Available for sale to the public, in paper, from: U.S. Department of Commerce, National Technical Information Service, 5285 Port Royal Road, Springfield, VA 22161, phone: (800)

553-6847, fax: (703) 605-6900, email: orders@ntis.fedworld.gov online ordering: http://www.ntis.gov/ordering.htm

Available electronically at http://www.doe.gov/bridge

Available for a processing fee to U.S. Department of Energy and its contractors, in paper, from: U.S. Department of Energy, Office of Scientific and Technical Information, P.O. Box 62, Oak Ridge, TN 37831-0062, phone: (865 ) 576-8401, fax: (865) 576-5728, email: reports@ adonis.osti.gov 
WSRC-TR-2001-00069, Revision 0

Keywords: DWPF, CST, Sludge, SRAT, SME, Rheology

Retention: Permanent

\section{IMPACT OF CST ON THE RHEOLOGICAL CHARACTERISTICS OF DWPF MELTER FEED (U)}

E. K. Hansen

D. C. Koopman

P. R. Monson

Publication Date: March 7, 2001

Westinghouse Savannah River Company Savannah River Site Aiken, SC 29808

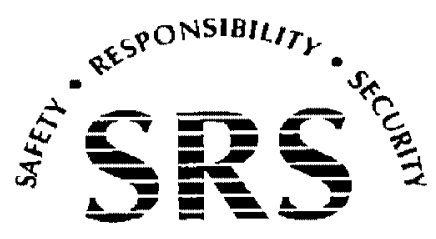

PREPARED FOR THE U.S. DEPARTMENT OF ENERGY UNDER CONTRACT NO. DE-AC09-96SR18500 
APPROVALS

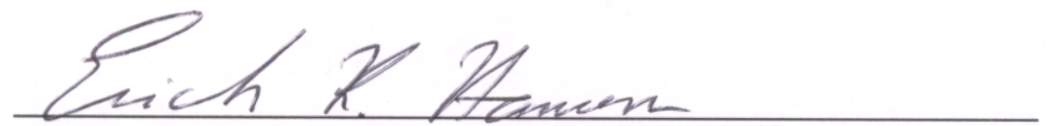

E. K. Hansen, Co-Author, Immobilization Technology

Laid torpor

D. C. Koopman, Cø-Author, Immobilization Technology

P. R. Manson, Co-Alithor (Retired), Immobilization Tech.

Russell P. Sileni

R. E. Eibling, Technical Reviewer

R. H. Spires, Manager, Immobilization Tech. \& Bus. Dev.

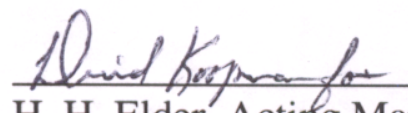

H. H. Elder, Acting Manager, Process Engineering

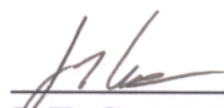

J. T. Carter, SWPF Director of Engineering

Slid K om for

D. W. Wester, TFA System Lead for CST

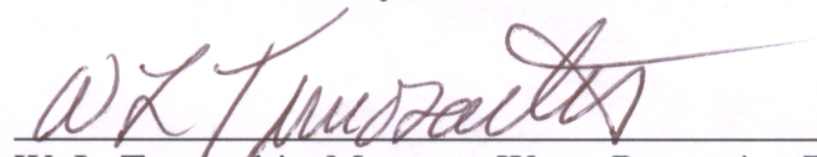

W. L. Tambsaitis, Manager, Waste Processing Technology
$3 / 1261$

Date

$3 / 12 / 2001$

Date

$3-16-01$

Date

$\frac{3 / 12 / 2001}{\text { Date }}$

$3-16-01$

Date

3.27 .01

Date

$3 / 22 / 01$

Date

$3 / 28 / 01$

Date

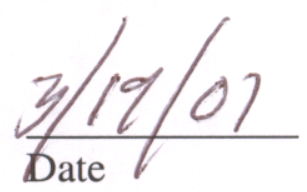


WSRC-TR-2001-00069

Page $v$

TABLE OF CONTENTS

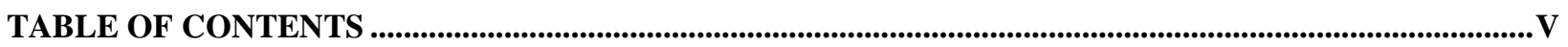

LIST OF FIGURES.............................................................................................................................. VI

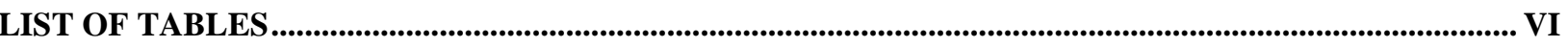

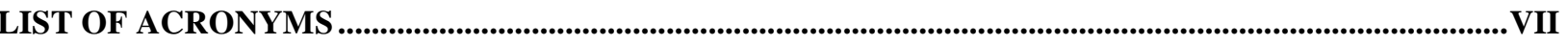

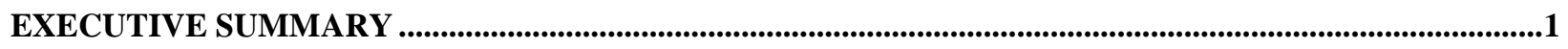

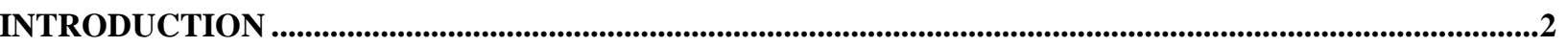

EXPERIMENTAL METHOD .........................................................................................................................................3

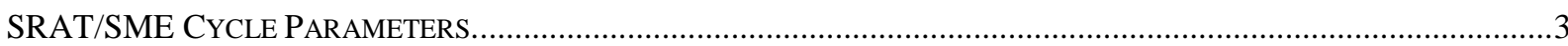

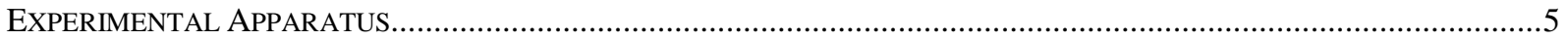

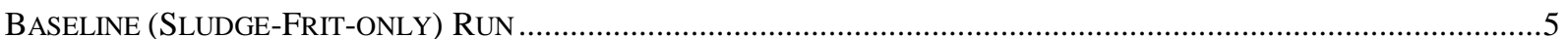

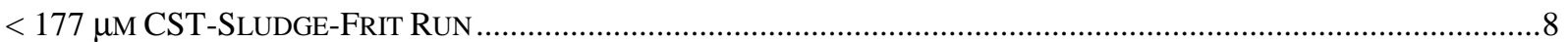

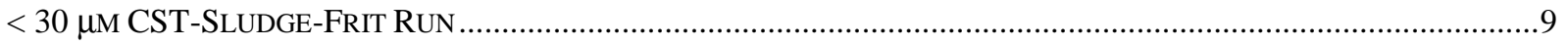

PHYSICAL \& RHEOLOGY RESULTS...................................................................................................11

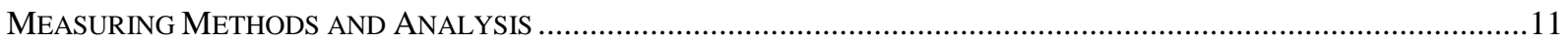

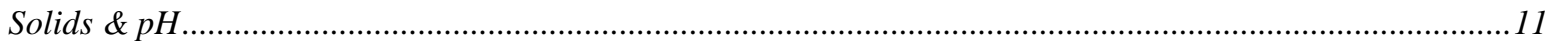

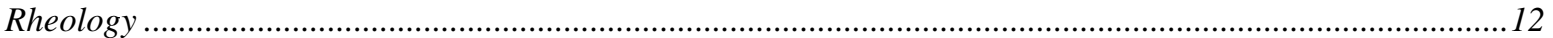

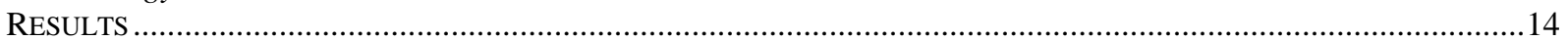

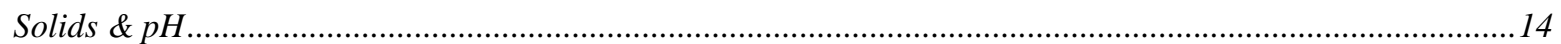

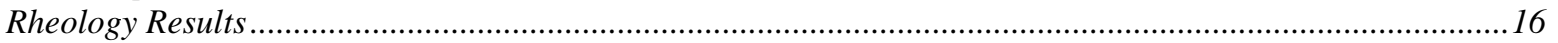

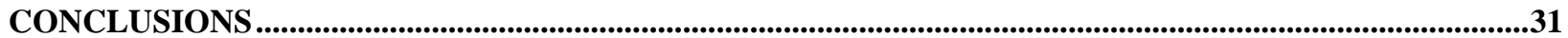

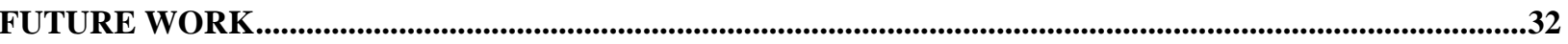

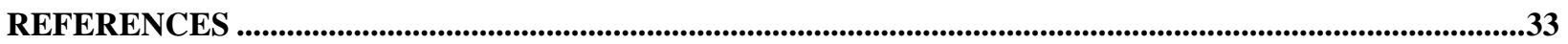

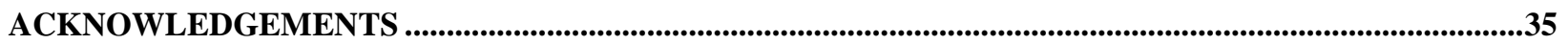

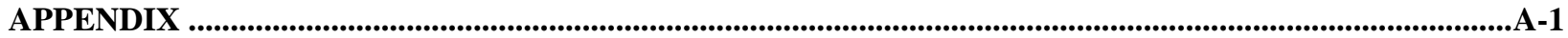


WSRC-TR-2001-00069

Page vi

\section{LIST OF FIGURES}

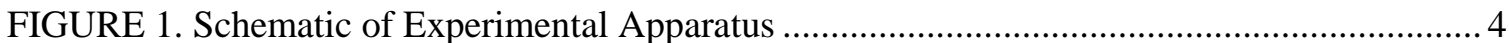

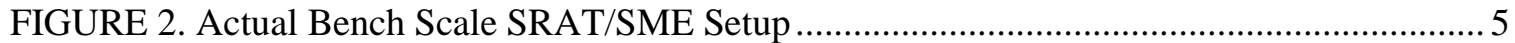

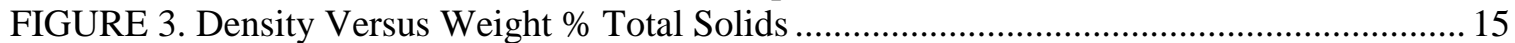

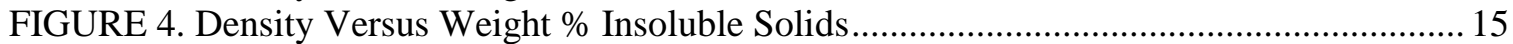

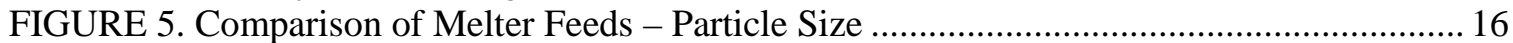

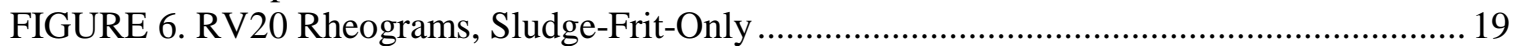
FIGURE 7. RS150 Rheograms, Sludge-Frit-Only ..................................................... 19

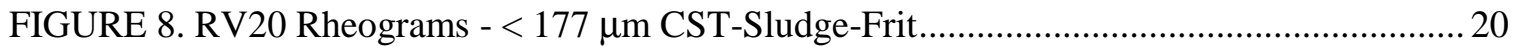
FIGURE 9. RS150 Rheograms - < $177 \mu \mathrm{m}$ CST-Sludge-Frit ................................................ 20

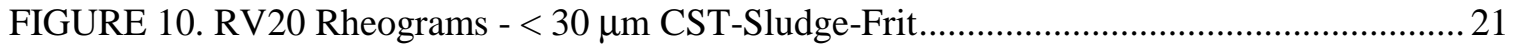

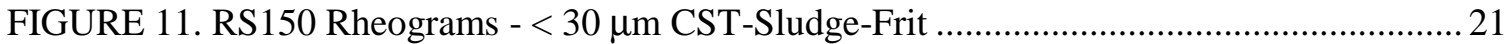

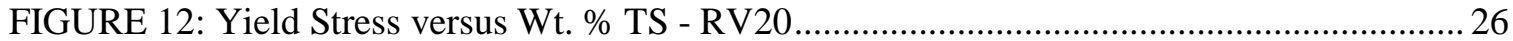

FIGURE 13: Yield Stress versus Wt. \% TS - RS150 …........................................................ 26

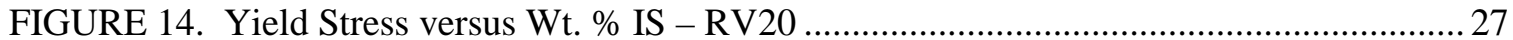

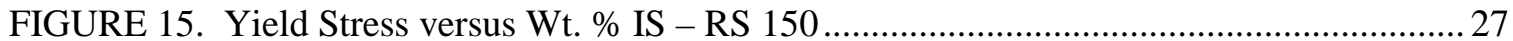

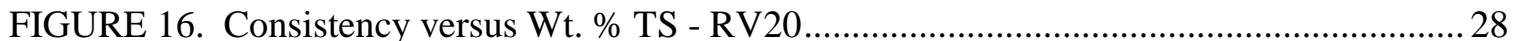

FIGURE 17. Consistency versus Wt. \% TS - RS150 ........................................................... 28

FIGURE 18. Consistency versus Wt. \% IS - RV20 ................................................................29

FIGURE 19. Consistency versus Wt. \% IS - RS150 ..............................................................29

FIGURE 20. Flow Curves Using Equation [6] and wt. \% TS ........................................ 31

\section{LIST OF TABLES}

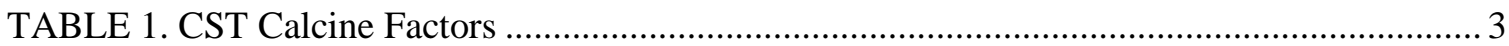

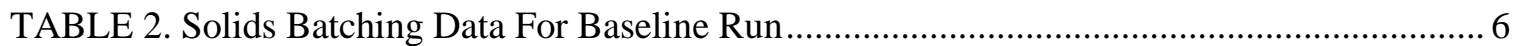
TABLE 3. Input Data For REDOX Calculation (Excluding Cations) ........................................ 6

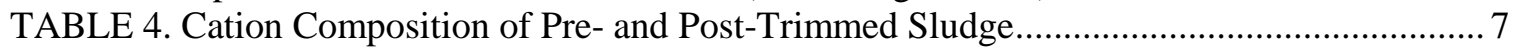

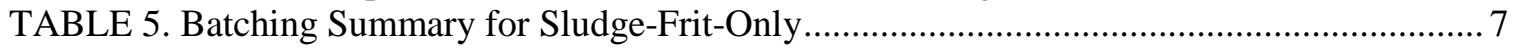
TABLE 6. Solids Batching Data for < $177 \mu \mathrm{m}$ CST-sludge-frit Run ........................................ 8 TABLE 7. Batching Summary for Run with < $177 \mu \mathrm{m}$ CST-Sludge-Frit ................................... 9 TABLE 8. Solids Batching Data for < $30 \mu \mathrm{m}$ CST-Sludge-Frit Run ...................................... 10 TABLE 9. Batching Summary for Run with $<30 \mu \mathrm{m}$ CST-Sludge-Frit .................................. 10 TABLE 10. RS150 Measurement Job Programs ................................................................ 12

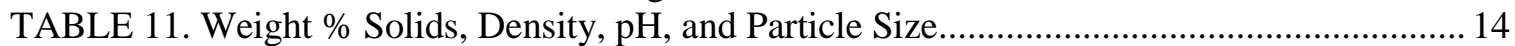

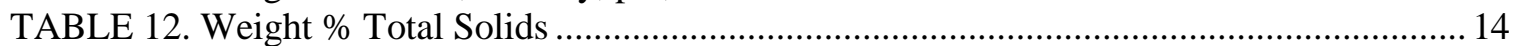
TABLE 13. Bingham Plastic Model Parameters ............................................................. 18 TABLE 14. Curves Fitted To Bingham Plastic Model Parameter to Wt. \% Solids...................... 23 TABLE 15. Observations From RV20 …...................................................................... 24

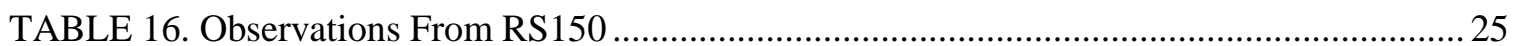


WSRC-TR-2001-00069

Page vii

\section{LIST OF ACRONYMS}

CST

IS

DWPF

LFL

MFT

MST

SRAT

SME

TS
Crystalline Silicotitanate

Insoluble Solids

Defense Waste Processing Facility

Lower Flammability Limit

Melter Feed Tank

Monosodium Titanate

Sludge Receipt and Adjustment Tank

Slurry Mix Evaporator

Total Solids 
WSRC-TR-2001-00069

Page 1 of 35

\section{EXECUTIVE SUMMARY}

An excessively high yield stress for size-reduced $(<125 \mu \mathrm{m})$ CST-Sludge-Frit DWPF melter feed was observed in a previous study ${ }^{1}$. This may have been due to the fact that the slurry was a year old, that it contained CST, that it contained two different frits, that it had undergone various physical manipulations, and/or other factors.

The purpose of this study was to produce fresh melter feeds based on:

(1) Tank 8/Tank 40 Blend (Sludge-Frit-only)

(2) Fine $(<30 \mu \mathrm{m})$ CST - Tank $8 / 40$ Blend $(<30 \mu \mathrm{m}$ CST-Sludge-Frit $)$

(3) Coarse $(<177 \mu \mathrm{m}$ CST) - Tank 8/40 Blend $(<177 \mu \mathrm{m}$ CST-Sludge-Frit).

Melter feeds were prepared using a prototypical bench-scale DWPF Chemical Process Cell (SRAT/SME) simulation. All three bench-scale runs were completed between November 13-22. Processing conditions corresponded to the nominal Tank $8 / 40$ sludge blend case developed in September $2000^{2}$.

Rheograms were run shortly after the completion of the SRAT/SME simulations on six different solids concentration for each melter feed. This permitted a comparison between the three melter feeds without the issues of variations in processing conditions, material age, and handling history.

The analysis of the rheograms showed the expected pattern of increasing yield stress and consistency with increasing solids content for the different melter feeds. All the melter feeds exceeded the DWPF design basis yield stress at approximately $42 \mathrm{wt}$. \% total solids, which was comparable to another study ${ }^{13}$. At low wt. \% solids, the behavior of the Sludge-frit-only, < 177 $\mu \mathrm{m}$ CST-sludge-frit, and $<30 \mu \mathrm{m}$ CST-sludge-frit slurries were the same rheologically. As the wt. \% solids increased, the $<177 \mu \mathrm{m}$ CST-sludge-frit was the most viscous, followed by the $<30$ $\mu \mathrm{m}$ CST-sludge-frit, and then the Sludge-frit-only slurry. The change was most notable in the yield stress.

The yield stresses of CST-sludge-frit melter feeds equaled the yield stresses of sludge-frit-only melter feeds that contained higher weight $\%$ total solids. The difference in weight percent total solids between the CST-sludge-frit and sludge-frit-only melter feeds was anywhere from 0 to 4 wt. \% total solids, depending on the selected yield stress. This means that the presence of CST in the DWPF melter feed would potentially lead to a reduction in melt rate due to the additional water in the CST-sludge-frit melter feeds.

This work was in response to TTR: HLW-SDT-TTR-2000-00014. 
WSRC-TR-2001-00069

Page 2 of 35

\section{INTRODUCTION}

One of the candidate salt processing alternatives involves using ion-exchange columns filled with CST sorbent to remove the highly radioactive cesium from the high level salt waste. The cesium bearing CST would then be processed through the DWPF. CST is added to the SRAT cycle as a slurry. The SRAT product containing CST, would be transferred to the Slurry Mix Evaporator (SME), then to the Melter Feed Tank (MFT), and finally fed to the melter. The CST would ultimately end up in the DWPF waste glass canisters.

One of the DWPF processing concerns was the impact of size-reduced CST on the rheological characteristics of DWPF melter feed. In a previous study ${ }^{1}$, a CST $(<125 \mu \mathrm{m})$-Macrobatch 2 Sludge-Frit mixture of $50.5 \mathrm{wt}$. \% total solids exhibited excessively high yield stress $(\sim 400$ dynes $/ \mathrm{cm}^{2}$ ). This yield stress was more than double the upper DWPF design basis of 150 dynes $/ \mathrm{cm}^{2}$.

One of the postulated reasons for the high yield stress in the CST-Sludge-Frit melter feed was that it was about nine months old. For this reason it was decided that a new study was necessary to further investigate the rheological characteristics using freshly produced melter feeds containing CST.

If a high yield stress was an inherent property of CST-Sludge-Frit slurries, then it could lead to reduced melter-processing rates from the extra water required to reduce the yield stress of the CST-Sludge-Frit slurry to within either the DWPF design basis limits or the DWPF real processability limits.

Another factor that could have led to this high yield stress was the particle size distribution of the size-reduced CST. The previous study ${ }^{1}$ used a CST-water slurry, in which the CST was size reduced to less the $125 \mu \mathrm{m}$, which had a volume mean diameter of $15 \mu^{3}{ }^{3}$. For this reason, it was decided to expand this study to investigate the effects on rheology for two different size reduced CST-Sludge-Frit melter feed slurries.

The following differences in preparing the slurries between the previous study ${ }^{1}$ and this study are summarized below:

- The 1999 and 2000 melter feeds were "old" (many months) when the rheological characterization was done, while this work used fresh melter feed.

- The size-reduced CST in the 1999 and 2000 melter feeds was loaded with caustic and noble metals before SRAT processing. The CST in this study was not loaded.

- The 1999 size-reduced CST was prepared using a pump, which produced a broad particle size distribution. The CST used in this study was size-reduced by grinders.

- The 1999/2000 tests used Tank 42 (Macrobatch 2) sludge simulant. This study used Tank 8/Tank 40 blended sludge (Macrobatch 3 sludge simulant).

- The 1999/2000 tests used frit 202 with CST, while this study used frit 200.

- The 1999 no CST melter feed was 35\% sludge oxides, while the size-reduced CST melter feed was about $26 \%$ sludge oxides and $9 \%$ CST oxides, i.e. CST solids displaced sludge solids, while frit solids remained constant. In this study, CST solids displaced a fraction 
WSRC-TR-2001-00069

Page 3 of 35

of the frit (10 wt. \% CST oxides, 64 wt. \% frit), with sludge oxides remaining constant at $26 \%$.

\section{EXPERIMENTAL METHOD}

\section{SRAT/SME Cycle Parameters.}

Three DWPF melter feed preparation simulations (SRAT/SME cycles) were conducted using identical processing conditions, e.g. batch size, acid addition strategy, reflux periods, etc. The baseline run produced sludge-frit-only melter feed simulant. The other two runs combined different size-reduced CST with sludge and frit. One run produced $<30 \mu \mathrm{m}$ CST-sludge-frit melter feed simulant, and other run produced $<177 \mu \mathrm{m}$ CST-sludge-frit melter feed simulant.

Table 1 provides the measured CST-water slurry wt. \% total solids and calcine factors. The calcine factors were used to calculate the CST batching required to obtain the correct melter feed composition. The calcine factor here is defined as the mass of CST oxides at $900^{\circ} \mathrm{C}$ per gram of starting slurry. Note the variability in the $<177 \mu \mathrm{m}$ CST was much greater than the $<30 \mu \mathrm{m}$ CST. The variability in the $<177$ CST was related to the greater sampling difficulties caused by the rapid settling of the larger-sized CST particles.

The starting sludge simulant used in all three runs was identical. It was a blend of $48 \%$ Tank 8 sludge simulant to 52\% Tank 40 sludge simulant by total solids content (DWPF Macrobatch 3). The Tank 40 sludge simulant had been determined to be low in nickel and manganese relative to real Tank 40 waste. It was decided that there was no need to trim the simulant with additional nickel or manganese to meet the objectives of this task, which was to determine the "relative" rheological characteristics of the melter feeds with and without CST.

TABLE 1. CST Calcine Factors

\begin{tabular}{|c|c|c|c|c|}
\hline \multirow{2}{*}{ Sample \# } & \multicolumn{2}{|c|}{ CST in Water $<30 \mu \mathrm{m}$} & \multicolumn{2}{c|}{ CST in Water $<\mathbf{1 7 7} \boldsymbol{\mu m}$} \\
\cline { 2 - 5 } & $\begin{array}{c}\text { Wt. \% } \\
\text { Total } \\
\text { Solids }\end{array}$ & $\begin{array}{c}\text { Calcine } \\
\text { Factor }\end{array}$ & $\begin{array}{c}\text { Wt. \% } \\
\text { Total } \\
\text { Solids }\end{array}$ & $\begin{array}{c}\text { Calcine } \\
\text { Factor }\end{array}$ \\
\hline$\# 1$ & 21.05 & 0.1779 & 7.09 & 0.0591 \\
\hline$\# 2$ & 21.02 & 0.1783 & 7.46 & 0.0624 \\
\hline$\# 3$ & 20.97 & 0.1782 & 8.18 & 0.0683 \\
\hline Average & $\mathbf{2 1 . 0 1}$ & $\mathbf{0 . 1 7 8 1}$ & $\mathbf{7 . 5 8}$ & $\mathbf{0 . 0 6 3 3}$ \\
\hline
\end{tabular}

No monosodium titanate, or MST, was included in the melter feed batching calculations. This was also the case with the melter feeds prepared for the Hydragard tests ${ }^{1}$. The noble metals basis used an analysis of a recent sample of real Tank 40 waste performed by N. Bibler and T. Fellinger [Ref. 3, Appendix B]. The Tank 8 noble metals were per the High Level Waste database $^{7}$. This was consistent with the flowsheet study work ${ }^{2}$. Noble metals affect rheology through their chemical action on the anion content of the slurry. The run plans used in this study ${ }^{4,5,6}$ were based on $110 \%$ of the noble metal concentrations projected for the nominal blend of the above described sludges. Mercury was added as $\mathrm{HgO}$ using a weighted blend of Tank 8 and 40 concentrations expected from the High Level Waste database. 
WSRC-TR-2001-00069

Page 4 of 35

A batch size of 3000 grams of untrimmed sludge simulant was used for each run. The batches were trimmed with the noble metals and mercury prior to starting the SRAT cycle. $125 \%$ of the stoichiometric acid requirement was used. The ratio of formic acid to nitric acid was fixed by selecting a melter feed redox target of $0.2 \mathrm{Fe}^{+2} / \mathrm{Fe}_{\text {total }}$. The CST-water slurries were batched during the SRAT cycle boiling period. Several batch additions were required to obtain the targeted CST concentration. The water in the CST-water slurry was boiled off before another batch of CST-water slurry was added. Dry frit 200 was added to start the SME cycle, after all the CST-water slurry had been added. This CST-sludge-frit slurry was then mixed for 5 hours, during which the condensable vapors were primarily refluxed back into the slurry. A conservative air sparge flow rate was chosen (based on earlier melter feed preparation simulations) to ensure that the hydrogen concentration remained at or below 25\% of the LFL. This negated the need for operating a gas chromatograph.

\section{FIGURE 1. Schematic of Experimental Apparatus}

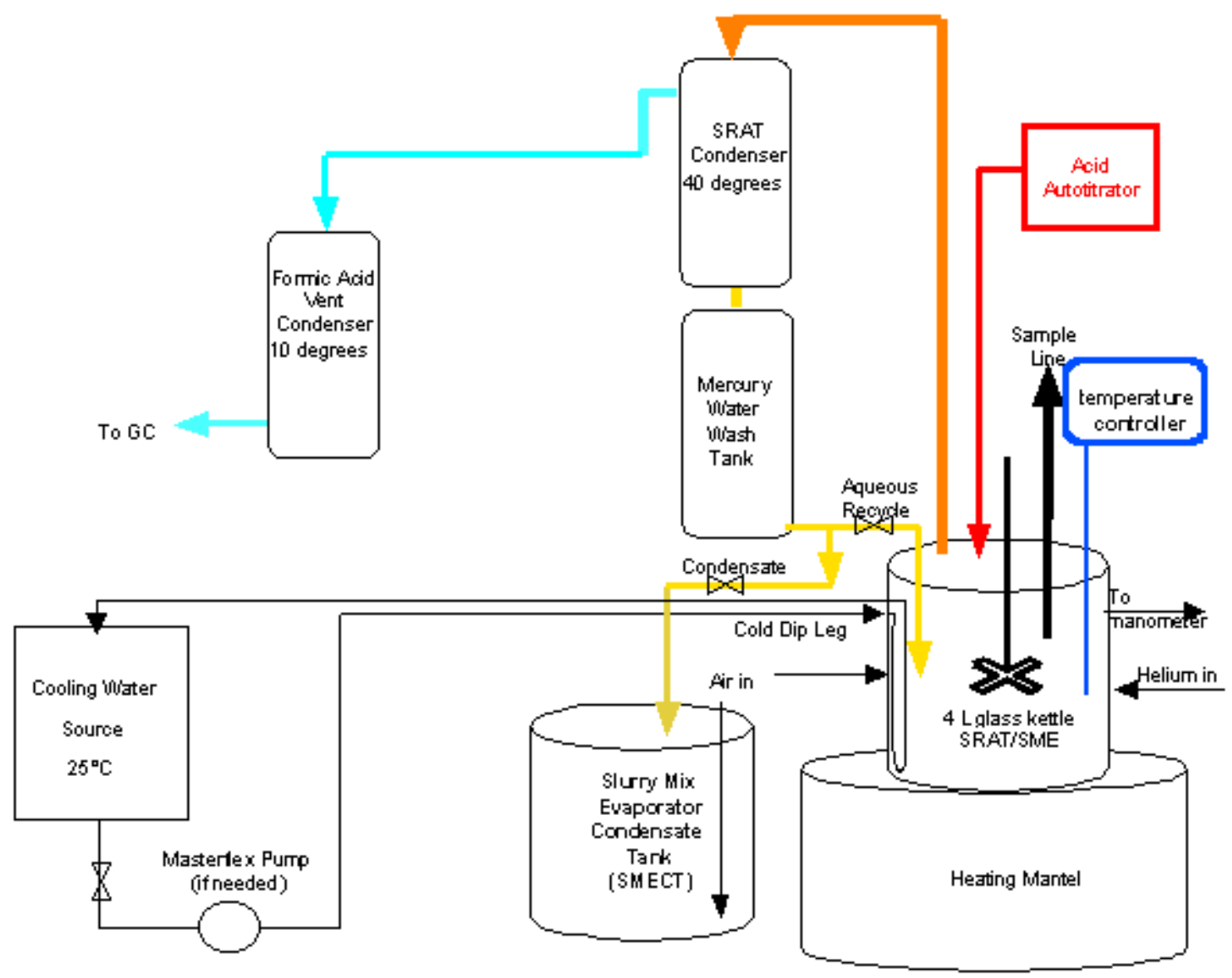

The SME product target was between 50 to $52 \mathrm{wt}$ \% total solids (TS) for each run. The baseline run (no CST added) targeted a 26\% sludge oxide to $74 \%$ frit oxide ratio. The melter feeds with CST targeted a mixture containing $26 \%$ sludge oxides, $10 \%$ CST oxides, and $64 \%$ frit oxides. Frit 200 was used in all runs. (Frit 202 was used in the 1999 runs $^{3}$ with CST.) 
WSRC-TR-2001-00069

Page 5 of 35

Some of the condensate produced during each SME cycle was collected (in separate containers). The condensate was then used to dilute aliquots of the original SME products to wt. \% TS ranging from $40 \mathrm{wt}$. \% TS up to $48 \mathrm{wt}$. \% TS in increments of $2 \mathrm{wt} . \%$. The original melter feeds, $50-52$ wt. \% TS, were also studied as-is. The rheological characteristics of each melter feed sample were obtained at $25^{\circ} \mathrm{C}$. Each melter feed was also analyzed for total solids, soluble solids in the supernate, density, and $\mathrm{pH}$.

\section{Experimental Apparatus}

The melter feed preparation work was controlled using the procedure for Laboratory Scale Chemical Process Cell Simulations (Manual L27, Procedure 2.02) and the individual Run Plans ${ }^{4}$, 5,6. A general review for Chemical Process Cell simulations, as required by the Conduct of Research and Development, has been completed ${ }^{8}$. A schematic diagram of the experimental apparatus is shown in Figure 1. An actual bench-scale setup of the SRAT/SME process is shown in Figure 2.

\section{FIGURE 2. Actual Bench Scale SRAT/SME Setup}

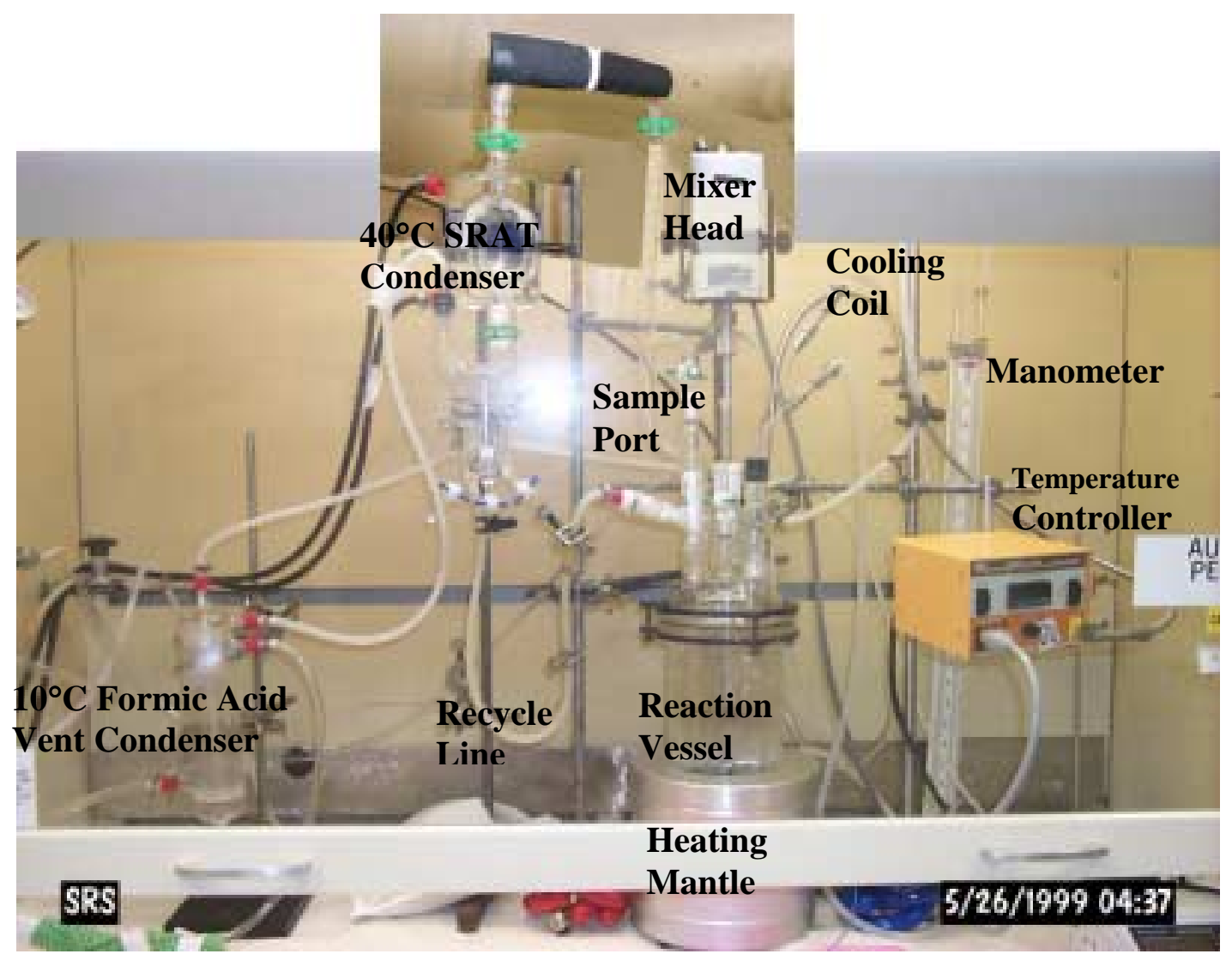

\section{Baseline (Sludge-Frit-only) Run}

The batching for glass make-up is described in Table 2 below. A complete description of the run can be found in the Run Plan'. 
WSRC-TR-2001-00069

Page 6 of 35

TABLE 2. Solids Batching Data For Baseline Run

\begin{tabular}{lcccc}
\hline \multicolumn{1}{c}{ Type } & Wt. \% Total Solids & Wt. \% Calcined Solids & Density, g/mL & Waste Loading, \% \\
\hline Untrimmed Sludge & 15.6 & 12.1 & 1.11 & 26.0 \\
Frit & 100 & 100 & 2.5 & 74.0 \\
\hline
\end{tabular}

The run used no heel. The calculation inputs for acids, anions, and redox are briefly summarized in Table 3.

TABLE 3. Input Data For REDOX Calculation (Excluding Cations)

\begin{tabular}{|l|r|}
\hline Sludge Hydroxide Equiv. @ $\mathrm{pH}=5.5, \mathrm{M}$ & 0.439 \\
\hline Overall Acid Stoichiometry & $125.0 \%$ \\
\hline Nitric Acid Molarity, M & 10.14 \\
\hline Formic Acid Molarity, M & 22.62 \\
\hline Initial Sludge Nitrite Conc., mg/L & 8500 \\
\hline Initial Sludge Nitrate Conc., mg/L & 3800 \\
\hline Assumed \% Nitrite Destruction & $100 \%$ \\
\hline Assumed \% Nitrite to Nitrate Conversion & $35 \%$ \\
\hline Initial Sludge Formate Conc., mg/L & 0 \\
\hline Assumed \% Formate Destruction & $15 \%$ \\
\hline Predicted Redox, Fe(II)/LFe & 0.20 \\
\hline
\end{tabular}

The starting sludge simulant is described in Table 4. Table 4 provides the best estimate of the composition of the untrimmed sludge, the quantities of mercury and noble metals to be added to meet target values (given in the Post-Trim column), and the predicted effect of these additions on the composition of the other sludge species. The values in the "At" column for palladium, rhodium, and ruthenium represent the weight per cent of elemental $\mathrm{Pd}, \mathrm{Rh}$, or $\mathrm{Ru}$ in their respective supply bottles.

The data in Tables 3 and 4 was used to produce the batching summary information in Table 5 for the sludge-frit-only slurry. 
WSRC-TR-2001-00069

Page 7 of 35

TABLE 4. Cation Composition of Pre- and Post-Trimmed Sludge

\begin{tabular}{|c|c|c|c|c|c|}
\hline & Initial & \multicolumn{3}{|c|}{ Trim Chemical Description } & Post-Trim \\
\hline Total & $3000.00 \mathrm{~g}$ & & & & $3009.14 \mathrm{~g}$ \\
\hline Species & & Trim with & At & Needs & Species \\
\hline $\mathrm{Al}$ & $8.32 \%$ & & & & $8.29 \%$ \\
\hline $\mathrm{Ag}$ & $0.00 \%$ & $\mathrm{AgNO}_{3}$ & $100.00 \%$ & $0.9412 \mathrm{~g}$ & $0.1270 \%$ \\
\hline $\mathrm{Ba}$ & $0.20 \%$ & & & & $0.20 \%$ \\
\hline $\mathrm{Ca}$ & $2.46 \%$ & & & & $2.45 \%$ \\
\hline $\mathrm{Cd}$ & $0.00 \%$ & & & & $0.00 \%$ \\
\hline $\mathrm{Cr}$ & $0.22 \%$ & & & & $0.22 \%$ \\
\hline $\mathrm{Cu}$ & $0.13 \%$ & & & & $0.13 \%$ \\
\hline $\mathrm{Fe}$ & $27.58 \%$ & & & & $27.50 \%$ \\
\hline $\mathrm{Hg}$ & $0.00 \%$ & $\mathrm{HgO}$ & $100.00 \%$ & $1.494 \mathrm{~g}$ & $0.29 \%$ \\
\hline K & $0.06 \%$ & & & & $0.06 \%$ \\
\hline $\mathrm{Mg}$ & $0.13 \%$ & & & & $0.13 \%$ \\
\hline $\mathrm{Mn}$ & $2.52 \%$ & & & & $2.51 \%$ \\
\hline $\mathrm{Na}$ & $6.04 \%$ & & & & $6.02 \%$ \\
\hline $\mathrm{Ni}$ & $1.52 \%$ & & & & $1.52 \%$ \\
\hline $\mathrm{P}$ & $0.27 \%$ & & & & $0.27 \%$ \\
\hline$\overline{\mathrm{Pb}}$ & $0.24 \%$ & & & & $0.24 \%$ \\
\hline $\mathrm{Pd}$ & $0.00 \%$ & $\mathrm{Pd}\left(\mathrm{NO}_{3}\right)_{2} * \mathrm{H}_{2} \mathrm{O}$ & $15.27 \%$ & $2.9993 \mathrm{~g}$ & $0.09730 \%$ \\
\hline $\mathrm{Rh}$ & $0.00 \%$ & $\mathrm{Rh}\left(\mathrm{NO}_{3}\right)_{3} * 2 \mathrm{H}_{2} \mathrm{O}$ & $4.93 \%$ & $1.4028 \mathrm{~g}$ & $0.01470 \%$ \\
\hline $\mathrm{Ru}$ & $0.00 \%$ & $\mathrm{RuCl}_{3}$ & $41.74 \%$ & $2.3062 \mathrm{~g}$ & $0.20450 \%$ \\
\hline $\mathrm{Se}$ & $0.00 \%$ & & & & $0.00 \%$ \\
\hline $\mathrm{Si}$ & $0.89 \%$ & & & & $0.89 \%$ \\
\hline $\mathrm{Sr}$ & $0.08 \%$ & & & & $0.08 \%$ \\
\hline $\mathrm{Ti}$ & $0.00 \%$ & & & & $0.00 \%$ \\
\hline $\mathrm{Zn}$ & $0.27 \%$ & & & & $0.27 \%$ \\
\hline $\mathrm{r}$ & $0.54 \%$ & & & & $0.54 \%$ \\
\hline
\end{tabular}

TABLE 5. Batching Summary for Sludge-Frit-Only

\begin{tabular}{|l|r|}
\hline DWPF Scale Factor & $\mathbf{8 4 0 3}$ \\
\hline Initial Sludge Mass, $\mathrm{g}$ & $\mathbf{3 0 0 0 . 0}$ \\
\hline Sludge Rinse Water, $\mathrm{ml}$ & $\mathbf{5 0 . 0 0}$ \\
\hline SRAT Nitric Acid, $\mathrm{ml}$ & $\mathbf{3 3 . 7 9}$ \\
\hline Nitric Acid Addition Rate, $\mathrm{ml} / \mathrm{min}$ & $\mathbf{0 . 9 2 4}$ \\
\hline Nitric Acid Addition Time, $\mathrm{hrs}$ & $\mathbf{0 . 6 0}$ \\
\hline SRAT Formic Acid, $\mathrm{ml}$ & $\mathbf{8 5 . 1 7}$ \\
\hline Formic Acid Addition Rate, $\mathrm{ml} / \mathrm{min}$ & $\mathbf{0 . 9 3 8}$ \\
\hline Formic Acid Addition Time, $\mathrm{hr}$ & $\mathbf{1 . 5 4}$ \\
\hline SRAT Dewater Mass, $\mathrm{g}$ & $\mathbf{2 1 0 . 9 6}$ \\
\hline SRAT Dewater Time, $\mathrm{hr}$ & $\mathbf{0 . 7 8}$ \\
\hline SME Frit Addition \#1, $\mathrm{g}$ & $\mathbf{4 9 4 . 2 7 4}$ \\
\hline Frit Addition \#1 Water, $\mathrm{g}$ & $\mathbf{6 0 . 0 0 0}$ \\
\hline Frit Addition \#1 Formic Acid, g & $\mathbf{1 0 . 0 6 9}$ \\
\hline SME Frit Addition \#2, $\mathrm{g}$ & $\mathbf{4 9 4 . 2 7 4}$ \\
\hline Frit Addition \#2 Water, $\mathrm{g}$ & $\mathbf{6 0 . 0 0 0}$ \\
\hline Frit Addition \#2 Formic Acid, g & $\mathbf{1 0 . 0 6 9}$ \\
\hline SRAT Air Purge, sccm & $\mathbf{6 3 3 . 5 6}$ \\
\hline Scaled Boil-up Rate, $\mathrm{g} / \mathrm{min}$ & $\mathbf{4 . 5 0}$ \\
\hline SME Air Purge, sccm & $\mathbf{2 2 2 . 4 2}$ \\
\hline
\end{tabular}


WSRC-TR-2001-00069

Page 8 of 35

Six different wt. \% TS samples were produced from this sludge-frit-only slurry. The analysis of rheology, solids, density, and $\mathrm{pH}$ are in the Results section. A sample of the original melter feed simulant produced was analyzed for composition. The ICP results for the elements were consistent with a $26 \%$ sludge oxide $-74 \%$ frit oxide product. The sample results are given in the Appendix and maintained in reference 16.

\section{$<177$ um CST-Sludge-Frit Run}

The batching for glass make-up is described in Table 6 below. A complete description of the run can be found in the Run Plan 5 .

\section{TABLE 6. Solids Batching Data for $<177 \mu \mathrm{m}$ CST-sludge-frit Run}

\begin{tabular}{lcccc}
\hline Type & Wt. \% Total Solids & Wt. \% Calcined Solids & Density, g/ml & Waste Loading \\
\hline Untrimmed Sludge & $15.6 \%$ & $12.1 \%$ & 1.11 & $26.0 \%$ \\
Frit & $100.0 \%$ & $100.0 \%$ & 2.5 & $64.0 \%$ \\
CST-Water Slurry & $7.6 \%$ & $6.3 \%$ & 1.03 & $10.0 \%$ \\
\hline
\end{tabular}

This run also required a CST-water slurry, where the particle size of the CST was less than 177 $\mu \mathrm{m}$. The calculation inputs for acids, anions, and redox were identical to those given in Table 3 , and the starting sludge simulant was described in Table 4. The data in Tables 3, 4, and 6 was used to produce the batching summary information in Table 7 for the $<177 \mu \mathrm{m}$ CST-sludge-frit slurry.

Six different wt. \% TS samples were produced from this the $<177 \mu \mathrm{m}$ CST-sludge-frit slurry. The analysis of rheology, solids, density, and $\mathrm{pH}$ are in the Results section. A sample of the original melter feed simulant produced was analyzed for composition. The ICP results for the elements were consistent with a $26 \%$ sludge oxide $-10 \%$ CST oxide $-64 \%$ frit oxide product. The sample results are given in the Appendix and maintained in reference 9. 
WSRC-TR-2001-00069

Page 9 of 35

TABLE 7. Batching Summary for Run with < $177 \mu \mathrm{m}$ CST-Sludge-Frit

\begin{tabular}{|c|c|}
\hline DWPF Scale Factor & 8403 \\
\hline Initial Sludge Mass, $\mathrm{g}$ & 3000.0 \\
\hline SRAT Heel Mass, $\mathrm{g}$ & 0.0 \\
\hline Sludge Rinse Water, $\mathrm{ml}$ & 50.00 \\
\hline SRAT Nitric Acid, ml & 33.79 \\
\hline Nitric Acid Addition Rate, $\mathrm{ml} / \mathrm{min}$ & 0.924 \\
\hline Nitric Acid Addition Time, hrs & 0.60 \\
\hline SRAT Formic Acid, ml & 85.17 \\
\hline Formic Acid Addition Rate, $\mathrm{ml} / \mathrm{min}$ & 0.938 \\
\hline Formic Acid Addition Time, $\mathrm{hr}$ & 1.54 \\
\hline SRAT Dewater Mass, $g$ & 310.96 \\
\hline SRAT Dewater Time, hrs & 1.15 \\
\hline$<177 \mu \mathrm{m}$ CST Slurry, g \#1 & 422.01 \\
\hline SRAT CST Dewater Mass, g \#1 & 390.02 \\
\hline CST Dewater Time, hrs & 1.45 \\
\hline$<177 \mu \mathrm{m}$ CST Slurry, g \#2 & 422.01 \\
\hline SRAT CST Dewater Mass, g \#2 & 390.02 \\
\hline CST Dewater Time, hrs & 1.45 \\
\hline$<177 \mu \mathrm{m}$ CST Slurry, g \#3 & 422.01 \\
\hline SRAT CST Dewater Mass, g \#3 & 390.02 \\
\hline CST Dewater Time, hrs & 1.45 \\
\hline$<177 \mu \mathrm{m}$ CST Slurry, g \#4 & 422.01 \\
\hline SRAT CST Dewater Mass, g \#4 & 390.02 \\
\hline CST Dewater Time, hrs & 1.45 \\
\hline$<177 \mu \mathrm{m}$ CST Slurry, g \#5 & 422.01 \\
\hline SRAT CST Dewater Mass, g \#5 & 390.02 \\
\hline CST Dewater Time, hrs & 1.45 \\
\hline SME Frit Addition $\# 1, \mathrm{~g}$ & 427.480 \\
\hline Frit Addition \#1 Water, $\mathrm{g}$ & 60.000 \\
\hline Frit Addition \#1 Formic Acid, g & 8.708 \\
\hline SME Frit Addition \#2, g & 427.480 \\
\hline Frit Addition \#2 Water, $\mathrm{g}$ & 60.000 \\
\hline Frit Addition \#2 Formic Acid, $g$ & 8.708 \\
\hline SRAT Air Purge, sccm & 633.56 \\
\hline Scaled Boil-up Rate, g/min & 4.50 \\
\hline SME Air Purge, sccm & 222.42 \\
\hline
\end{tabular}

\section{$<30 \mu m$ CST-Sludge-Frit Run}

The batching for glass make-up is described in Table 8. A complete description of the run can be found in the Run Plan'. 
WSRC-TR-2001-00069

Page 10 of 35

TABLE 8. Solids Batching Data for $<30 \mu \mathrm{m}$ CST-Sludge-Frit Run

\begin{tabular}{lcccc}
\hline Type & Wt. \% Total Solids & Wt. \% Calcined Solids & Density, g/ml & Waste Loading \\
\hline Untrimmed Sludge & $15.6 \%$ & $12.1 \%$ & 1.11 & $26.0 \%$ \\
Frit & $100.0 \%$ & $100.0 \%$ & 2.5 & $64.0 \%$ \\
CST-Water Slurry & $21.0 \%$ & $17.8 \%$ & 1.05 & $10.0 \%$ \\
\hline
\end{tabular}

This run also required a CST-water slurry, where the particle size of the CST was less than 30 $\mu \mathrm{m}$. The batch size was 3000 grams of untrimmed sludge. The calculation inputs for acids, anions, and redox were identical to those given in Table 3, and the starting sludge simulant was described in Table 4 . The data in Tables 3,4 , and 8 was used to produce the batching summary information given in Table 9 for the $<30 \mu \mathrm{m}$ CST-sludge-frit slurry.

TABLE 9. Batching Summary for Run with $<30 \mu \mathrm{m}$ CST-Sludge-Frit

\begin{tabular}{|c|c|}
\hline DWPF Scale Factor & 8403 \\
\hline Initial Sludge Mass, $\mathrm{g}$ & 3000.0 \\
\hline SRAT Heel Mass, g & $\mathbf{0 . 0}$ \\
\hline Sludge Rinse Water, ml & 50.00 \\
\hline SRAT Nitric Acid, ml & 33.79 \\
\hline Nitric Acid Addition Rate, ml/min & 0.924 \\
\hline Nitric Acid Addition Time, hrs & 0.60 \\
\hline SRAT Formic Acid, ml & 85.17 \\
\hline Formic Acid Addition Rate, $\mathrm{ml} / \mathrm{min}$ & 0.938 \\
\hline Formic Acid Addition Time, $\mathrm{hr}$ & 1.54 \\
\hline SRAT Dewater Mass, $\mathrm{g}$ & 310.96 \\
\hline SRAT Dewater Time, hrs & 1.15 \\
\hline $\begin{array}{l}<30 \mu \mathrm{m} \text { CST Slurry, } \mathrm{g} \# 1 \\
\text { SRAT CST Dewater Mass, } \mathrm{g} \# 1 \text { ) }\end{array}$ & $\begin{array}{l}373.47 \\
295.00\end{array}$ \\
\hline CST Dewater Time, hrs & 1.09 \\
\hline$<30 \mu \mathrm{m}$ CST Slurry, g \#2 & 373.47 \\
\hline SRAT CST Dewater Mass, g \# 2) & 295.00 \\
\hline CST Dewater Time, hrs & 1.09 \\
\hline SME Frit Addition \#1, g & 425.764 \\
\hline Frit Addition \#1 Water, $\mathrm{g}$ & 60.000 \\
\hline Frit Addition \#1 Formic Acid, g & 8.673 \\
\hline SME Frit Addition \#2, g & 425.764 \\
\hline Frit Addition \#2 Water, g & 60.000 \\
\hline Frit Addition \#2 Formic Acid, g & 8.673 \\
\hline SRAT Air Purge, sccm & 633.56 \\
\hline Scaled Boil-up Rate, g/min & 4.50 \\
\hline SME Air Purge, $\mathrm{sccm}$ & 222.42 \\
\hline
\end{tabular}

Six different wt. \% TS samples were produced from this $<30 \mu \mathrm{m}$ CST-sludge-frit slurry. The analysis of rheology, solids, density, and $\mathrm{pH}$ are given in the Results section. A sample of the original melter feed simulant produced was analyzed for composition. The ICP results for the elements were not consistent with a $26 \%$ sludge oxide $-10 \%$ CST oxide $-64 \%$ frit oxide product. The results matched a roughly $26.8 \%$ sludge oxide $-7.3 \%$ CST oxide $-65.9 \%$ frit oxide blend. (Uncertainties in these numbers are of order $\pm 0.5 \%$. The primary source of the 
WSRC-TR-2001-00069

Page 11 of 35

uncertainty being the precise composition of the sludge oxides.) The sample results are given in the Appendix and maintained in reference 9.

\section{PHYSICAL \& RHEOLOGY RESULTS}

\section{Measuring Methods and Analysis}

Slurry samples were analyzed for various physical properties in support of the rheology work. These included the weight percent (wt.) \% total solids (TS), wt. \% insoluble solids (IS), particle size distribution, slurry $\mathrm{pH}$, and rheology.

Solids \& $p H$

The weight percent solids were determined by oven-drying the samples between $105-115^{\circ} \mathrm{C}$ overnight. Slurry samples were dried to determine the wt. \% TS. To obtain a sample of the supernate, a portion of the slurry was first centrifuged and then the liquid phase was filtered through a 0.45 micron filter. The supernate was then oven-dried to determine the wt. \% dissolved solids concentration in the supernate. Duplicate samples of the slurry and supernate were dried and averaged. Wt. \% IS concentration in the slurry samples were then calculated using equation $[1]^{10}$ :

$$
w t . \%_{i s}=\frac{w t . \%_{t s}-w t . \%_{d s}}{100 \%-w t . \%_{d s}} \cdot 100 \%
$$

Where: $\quad w t . \%_{t s}=$ weight percent total solids concentration in the slurry

$w t . \%_{d s}=$ weight percent dissolved solids concentration in the supernate

$w t . \%_{\text {is }}=$ weight percent insoluble solids concentration in the slurry

Density measurements were made using a specific gravity cup and cap unit. The cup/cap was first tared in a calibrated weigh scale, the sample was placed into the cup and then the cap was used to press out excess sample and the excess sample removed. The mass of the cup/sample/cap was then measured on the calibrated weigh scale. This mass was divided by the known volume $\left(8.321 \mathrm{~cm}^{3}\right)$ of the cup to determine the density of the slurry. The volume of the cup was verified using water.

Measurements of $\mathrm{pH}$ were made using a Fisher Scientific accumet ${ }^{\circledR}$ model $15 \mathrm{pH}$ meter. The instrument was calibrated using $\mathrm{pH} 4$ and $\mathrm{pH} 10$ buffer solutions, and then checked against a $\mathrm{pH}$ 7 buffer. Indicated instrument results were within $0.1 \mathrm{pH}$ unit for the $\mathrm{pH} 7$ buffer. Particle size distributions were measured using a MicroTrac-SRA150 particle analyzer. Samples were run in duplicate and averaged. The particle size distribution scans from this study are located in the Appendix. 
WSRC-TR-2001-00069

Page 12 of 35

\section{Rheology}

Slurry rheology was characterized using both Haake RV20 (with an M5 measuring head) and Haake RS150 rheometers. Both rheometers are considered Searle type measuring systems, where both the speed and torque are measured at the rotating shaft.

The RV20 rheometer is a controlled rate (where the shear rate is applied and the resulting shear stress is measured) rheometer. A concentric cylindrical geometry was used to measure the flow properties. The MV2 stainless steel cylindrical rotor (36.8 $\mathrm{mm}$ outside diameter, $60 \mathrm{~mm}$ length), with a recessed bottom to reduce end effects, was the inner cylinder. The MV2 rotor was then attached to the M5 measuring head driver motor. A slurry sample was placed into a cylindrical stainless cup (42 $\mathrm{mm}$ inside diameter) and loaded into the heating jacket. The heating jacket controlled the temperature of the rotor, sample and cup. A heating/cooling temperature bath was attached to the heating jacket to provide the heat sink. All measurements were taken at $25^{\circ} \mathrm{C}$. All rheology measurements were taken using a linear shear rate ramp from 0 to $350 \mathrm{sec}^{-1}$ in five minutes, holding the shear rate at $350 \mathrm{sec}^{-1}$ for two minutes, and then linearly decreasing the shear rate from 350 to $0 \mathrm{sec}^{-1}$ in five minutes.

The RS150 rheometer can be run using either the controlled rate or controlled stress modes. In this study, only the controlled rate mode was used. Parallel-plate geometry was used to measure all the flow properties. A $60 \mathrm{~mm}$ stainless steel measuring plate was initially attached to the plate-heating jacket. The PP60 titanium rotor (60 mm outside diameter, flat plate) with a vapor trap was attached to the RS150. The RS150, controlled via software, initially finds the zero point (distance between PP60 and measuring plate is zero) and then the sample is loaded onto the measuring plate. A gap setting (distance between the PP60 and measuring plate) of $1 \mathrm{~mm}$, used in all the measurements, was achieved using the RS150 software. Excess sample was trimmed from the exposed edge to minimize edge effects. Water (temperature between 28 to $30^{\circ} \mathrm{C}$ ) was added to the vapor trap reservoir to try and maintain vapor space humidity, since these slurries had a tendency to evaporate quickly during the measurement around the exposed edge. A heating/cooling temperature bath was attached to the plate-heating jacket to provide the heat sink. All measurements were taken at $25^{\circ} \mathrm{C}$. Rheology measurements were taken using two different linear rate ramp programs shown in Table 10.

TABLE 10. RS150 Measurement Job Programs

\begin{tabular}{|c|c|c|c|c|c|c|}
\hline \multirow{2}{*}{ Program } & \multicolumn{2}{|c|}{ Linear shear rate ramp (up) } & \multicolumn{2}{c|}{ Holding shear rate } & \multicolumn{2}{c|}{ Linear shear rate ramp (down) } \\
\cline { 2 - 7 } & range $\left(\mathrm{sec}^{-1}\right)$ & time (min) & range $\left(\mathrm{sec}^{-1}\right)$ & time (min) & range $\left(\mathrm{sec}^{-1}\right)$ & time (min) \\
\hline A & $0-400$ & 5 & 400 & 1 & $400-0$ & 5 \\
\hline B & $0-1000$ & 5 & 1000 & 1 & $1000-0$ & 5 \\
\hline
\end{tabular}

Both the RV20 and RS150 rheometers were functionally checked using either a 102.5 or $101.9 \mathrm{cP}$ silicon oil standards at $25^{\circ} \mathrm{C}$ on each day that the instruments were to be used for measurement. Results for the standards were always within $\pm 5 \%$. The RS150 measuring plate was checked on a weekly basis to verify that the measuring surface was level.

The resulting flow curves obtained from both the cylindrical and plate-to-plate geometries have not been corrected for slip, viscous/thermal effects, or end/edge effects. No secondary flow problems, such as Taylor vortices were noted in any of these measurements. Since no 
WSRC-TR-2001-00069

Page 13 of 35

corrections were performed, the cylindrical and plate geometries do not produce identical flow curves. Correcting the flow curves would require taking additional rheological measurements using different size rotors and/or gaps. Flow curves corrected for non-Newtonian behavior would indicate that the fluid would be easier to flow, in the case for the shear-thinning slurries in this study. Correcting for slip would cause the flow curves to become thicker, and this correction is done after the non-Newtonian correction.

The flow curves were modeled using the Bingham Plastic rheological model, equation [2].

$$
\tau=\tau_{o}+\eta \dot{\gamma}
$$

Where: $\tau_{o}=$ Bingham plastic yield stress $\left(\mathrm{Pa}\right.$ or dynes $\left./ \mathrm{cm}^{2}\right)$

$\eta=$ Bingham Plastic consistency or Bingham plastic viscosity, (Pa-sec or cP)

$\dot{\gamma}=$ Shear rate $\left(\sec ^{-1}\right)$

$\tau=$ Shear stress $\left(\mathrm{Pa}\right.$ or dynes $\left./ \mathrm{cm}^{2}\right)$

The flow curves from the RV20 were fitted, using equation [2], between 100 to $350 \mathrm{sec}^{-1}$. For the RS150, the flow curves were fitted between 300 to $1000 \mathrm{sec}^{-1}$ but no flow curve was fitted to the 0 to $400 \mathrm{sec}^{-1}$ data. These fitting ranges were selected based on the region in which a linear function could be fitted to all the flow curves.

The DWPF design bases limits ${ }^{\mathbf{1 7}}$, using the Bingham Plastic model, are 25 to 150 dynes $/ \mathrm{cm}^{2}$ for yield stress and 10-40 centipoise (cP) for the plastic viscosity of the melter feed (SME product).

Marek ${ }^{11}$ modeled the two Bingham fluid parameters, as a function of wt. \% IS content of the slurry. The original theoretical model described the "apparent viscosity" of a Newtonian slurry ${ }^{\mathbf{1 2}}$ as a function of the volume fraction of insoluble solids. This equation ${ }^{\mathbf{2}}$ has been modified and used by Marek to model both the Bingham Plastic yield stress and consistency as separate functions of wt. \% IS concentration of the slurry. The resulting equations are shown below, equations [3] and [4]. Note that equations [3] and [4] force the solution at zero wt. \% IS (or TS) to intercept the axis at 1 (whatever units chosen). In this report, the wt. \% TS concentration will also be analyzed using equations [3] and [4]. The unknown parameters in equations [3] and [4] were obtained using Table Curve 2D software 4.06.

$$
\begin{aligned}
& \tau_{o}=\frac{\exp ^{b_{1} * C}}{\left(1-C / C_{\max , 1}\right)} \\
& \eta=\frac{\exp ^{b_{2}{ }^{*} C}}{\left(1-C / C_{\max , 2}\right)}
\end{aligned}
$$

Where: $\tau_{o}=$ yield stress from the Bingham Plastic model $\left(\mathrm{dynes} / \mathrm{cm}^{2}\right)$

$\eta \quad=$ plastic viscosity from the Bingham Plastic model (cP)

$C=$ insoluble or total solids concentration (wt. \%)

$C_{\text {max,i }}=$ model parameters corresponding to maximum wt. \% IS or TS

$b_{\mathrm{i}} \quad=$ model parameters (wt. \% IS or TS) ${ }^{-1}$ 
WSRC-TR-2001-00069

Page 14 of 35

\section{Results}

Solids \& $p H$

The wt. \% TS, wt. \% IS, density, $\mathrm{pH}$ and the averaged volume diameter $\left(\mathrm{m}_{\mathrm{v}}\right)$ of the sludges are given in Table 11. The wt. \% TS to wt. \% IS linear relationships for the various blends are shown in Table 12. Figure 3 contains all the density versus wt. $\%$ TS data and was fitted to the linear equation shown in Figure 3. Figure 4 contains all the density versus wt. \% IS data and was fitted to the linear equation shown in Figure 4. The linear equations in Table12, Figure 3, and Figure 4 were obtained using the statistical package in Microsoft EXCEL. The $\mathrm{pH}$ for all the blends ranged between 6.7 to 7.2 , which was similar to results obtained previously ${ }^{2}$.

TABLE 11. Weight \% Solids, Density, pH, and Particle Size

\begin{tabular}{|c|c|c|c|c|c|c|c|c|c|c|c|c|c|c|}
\hline \multicolumn{5}{|c|}{ Sludge-frit-only } & \multicolumn{5}{|c|}{$<177 \mu \mathrm{m}$ CST-sludge-frit } & \multicolumn{5}{|c|}{$<30 \mu \mathrm{m}$ CST-sludge-frit } \\
\hline $\begin{array}{c}\text { wt. } \% \\
\text { TS }\end{array}$ & $\begin{array}{c}\text { wt. } \% \\
\text { IS }\end{array}$ & $\begin{array}{c}\text { Density } \\
\mathrm{g} / \mathrm{mL}\end{array}$ & $\mathrm{pH}$ & $\begin{array}{c}\mathrm{m}_{\mathrm{v}} \\
(\mu \mathrm{m})\end{array}$ & $\begin{array}{c}\text { wt. } \% \\
\text { TS }\end{array}$ & $\begin{array}{c}\text { wt. } \% \\
\text { IS }\end{array}$ & $\begin{array}{l}\text { Density } \\
\mathrm{g} / \mathrm{mL}\end{array}$ & $\mathrm{pH}$ & $\begin{array}{c}\mathrm{m}_{\mathrm{v}} \\
(\mu \mathrm{m})\end{array}$ & $\begin{array}{c}\text { wt. } \% \\
\text { TS }\end{array}$ & $\begin{array}{c}\text { wt. } \% \\
\text { IS }\end{array}$ & $\begin{array}{l}\text { Density } \\
\mathrm{g} / \mathrm{mL}\end{array}$ & $\mathrm{pH}$ & $\begin{array}{c}\mathrm{m}_{\mathrm{v}} \\
(\mu \mathrm{m})\end{array}$ \\
\hline 39.2 & 35.0 & 1.219 & 7.17 & & 39.3 & 35.4 & 1.165 & 6.99 & & 39.1 & 34.6 & 1.114 & 7.12 & \\
\hline 40.9 & 36.4 & 1.227 & 7.05 & & 41.4 & 37.3 & 1.211 & 6.97 & & 41.0 & 36.2 & 1.197 & 7.1 & \\
\hline 43.3 & 38.6 & 1.254 & 7.17 & & 43.8 & 38.8 & 1.277 & 6.97 & & 43.2 & 38.3 & 1.218 & 7.06 & \\
\hline 46.1 & 41.1 & 1.300 & 7.06 & & 45.8 & 41.3 & 1.383 & 7.00 & & 45.2 & 40.0 & 1.303 & 7.06 & \\
\hline 47.7 & 42.7 & 1.379 & 7.08 & & 48.4 & 438 & 1.477 & 6.84 & & 47.3 & 41.9 & 1.390 & 7.08 & \\
\hline 52.1 & 46.8 & 1.523 & 6.95 & 155 & 52.2 & 46.8 & 1.505 & 6.68 & 138 & 48.9 & 43.4 & 1.486 & 7.02 & 132 \\
\hline
\end{tabular}

TABLE 12. Weight \% Total Solids

\begin{tabular}{|c|l|c|c|}
\hline & \multicolumn{1}{|c|}{ Equation } & Range (wt. \% IS) & $\mathrm{R}^{2}$ \\
\hline Sludge-frit-only & $(w t . \% T S)_{n o C S T}=1.20+1.089 \cdot(w t . \% I S)_{n o C S T}$ & $35.0-46.8$ & 0.9996 \\
\hline$<\mathbf{1 7 7 \mu m}$ CST-sludge-frit & $(w t . \% T S)_{<177 \mu m C S T}=0.26+1.110 \cdot(w t . \% I S)_{<177 \mu m C S T}$ & $35.4-46.8$ & 0.9954 \\
\hline$<\mathbf{3 0 \mu m}$ CST-sludge-frit & $(w t . \% T S)_{<30 \mu m C S T}=0.77+1.110 \cdot(w t . \% I S)_{<30 \mu m C S T}$ & $34.8-43.4$ & 0.9998 \\
\hline
\end{tabular}

The low total solids content of the $<30 \mu \mathrm{m}$ CST-sludge-frit original product, $48.9 \%$, relative to the other two original products, 52.1 and $52.2 \%$, appears to be due to issues related to the addition of the $<30 \mu \mathrm{m}$ CST-water slurry during the SRAT cycle. As mentioned in the preparation section above, this melter feed fell short of the CST oxide target of $10 \%$. The CSTwater slurry added during the SRAT cycle must have been thinner than expected based on the original solids measurements. This slurry must have been closer to $15 \%$ total solids than the $21 \%$ total solids listed in Table 1 . This led to a CST oxide content in the neighborhood of $7.3 \%$ (as seen in the ICP data), and equated to a $3.2 \%$ shortfall in product solids mass coupled with a $3.3 \%$ increase in product water mass (target was about 51\% solids and $49 \%$ water). The total solids content that correspond to these biases mathematically is $49.4 \%$, which is reasonably close to the measured value of $48.9 \%$. (Analysis of the dilution results for total solids suggests that the starting material was closer to $49.2-49.3 \%$ than to $48.9 \%$ as well). Problems with precise batching of CST slurries have been encountered previously ${ }^{3}$. 
WSRC-TR-2001-00069

Page 15 of 35

FIGURE 3. Density Versus Weight \% Total Solids

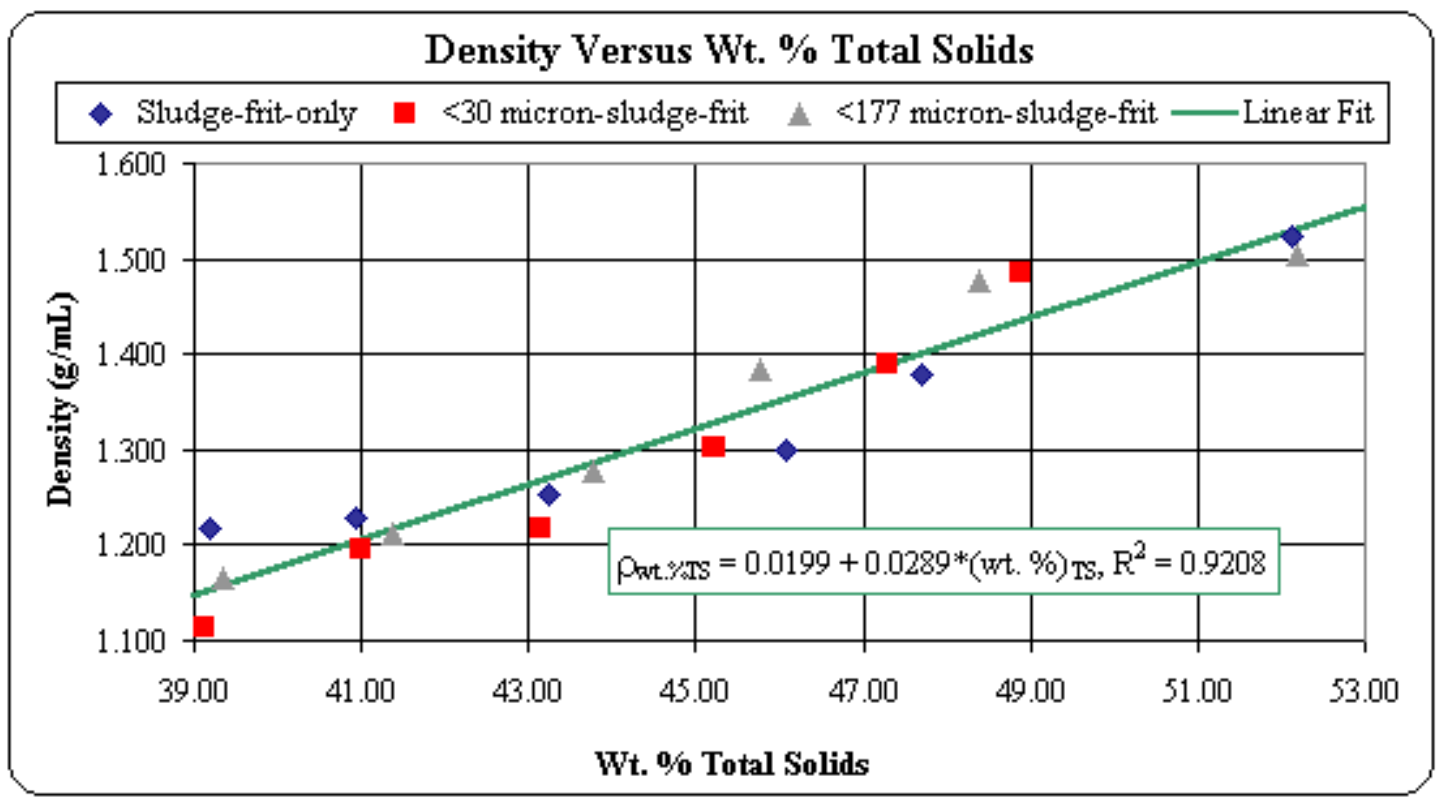

FIGURE 4. Density Versus Weight \% Insoluble Solids

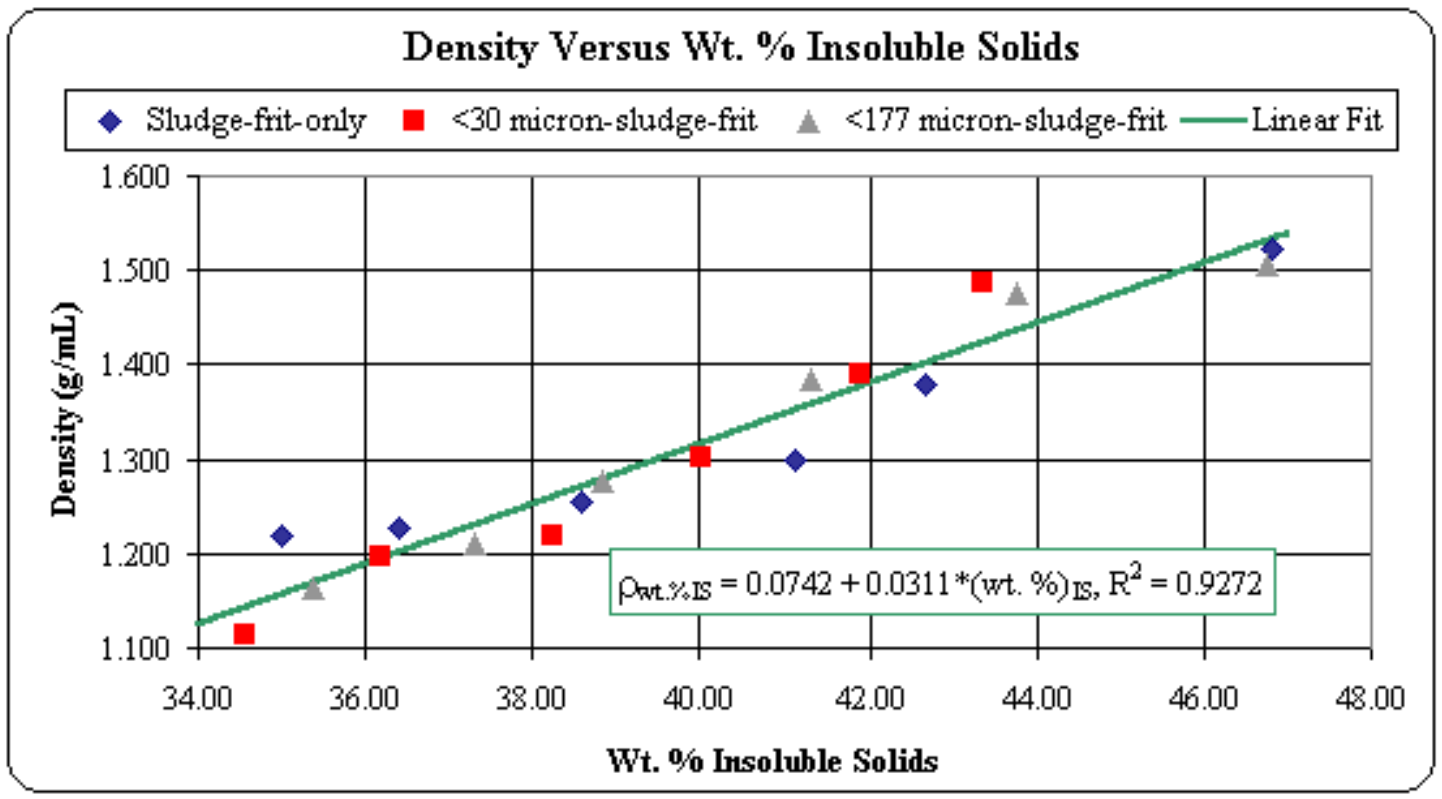

Figure 5 shows a comparison of the particle size distribution of the sludge-frit-only, $<177 \mu \mathrm{m}$ CST-sludge-frit and $<30 \mu \mathrm{m}$ CST-sludge-frit. The micron size on the $\mathrm{x}$-axis is the upper cut-off diameter in that measuring window. For example, the $11 \mu \mathrm{m}$ group would indicate that this is the volume percent of particles that passed the detector between 7.778 and $11.000 \mu \mathrm{m}$. As expected, the particle size distribution shifts from a larger to smaller sized particle distribution as frit was replaced with CST. The distribution shifted further to the left when comparing the $<30$ $\mu \mathrm{m}$ CST-sludge-frit to the $<177 \mu \mathrm{m}$ CST-sludge-frit, as expected. This shift was also evident by 
WSRC-TR-2001-00069

Page 16 of 35

the volume average diameter of the sludges listed in Table 11, where this volume average diameter decreased from the sludge-frit-only to $<177 \mu \mathrm{m}$ CST-sludge-frit to $<30 \mu \mathrm{m} \mathrm{CST}$ sludge-frit. The sludge-frit-only and $<177 \mu \mathrm{m}$ CST-sludge-frit seemed to have a more defined bi-modal distributions compared to the $<30 \mu \mathrm{m}$ CST-sludge-frit. Compared to the other two sludges, the $<30 \mu \mathrm{m}$ CST-sludge-frit particle size distribution was more evenly dispersed at particle sizes $<50 \mu \mathrm{m}$.

FIGURE 5. Comparison of Melter Feeds - Particle Size

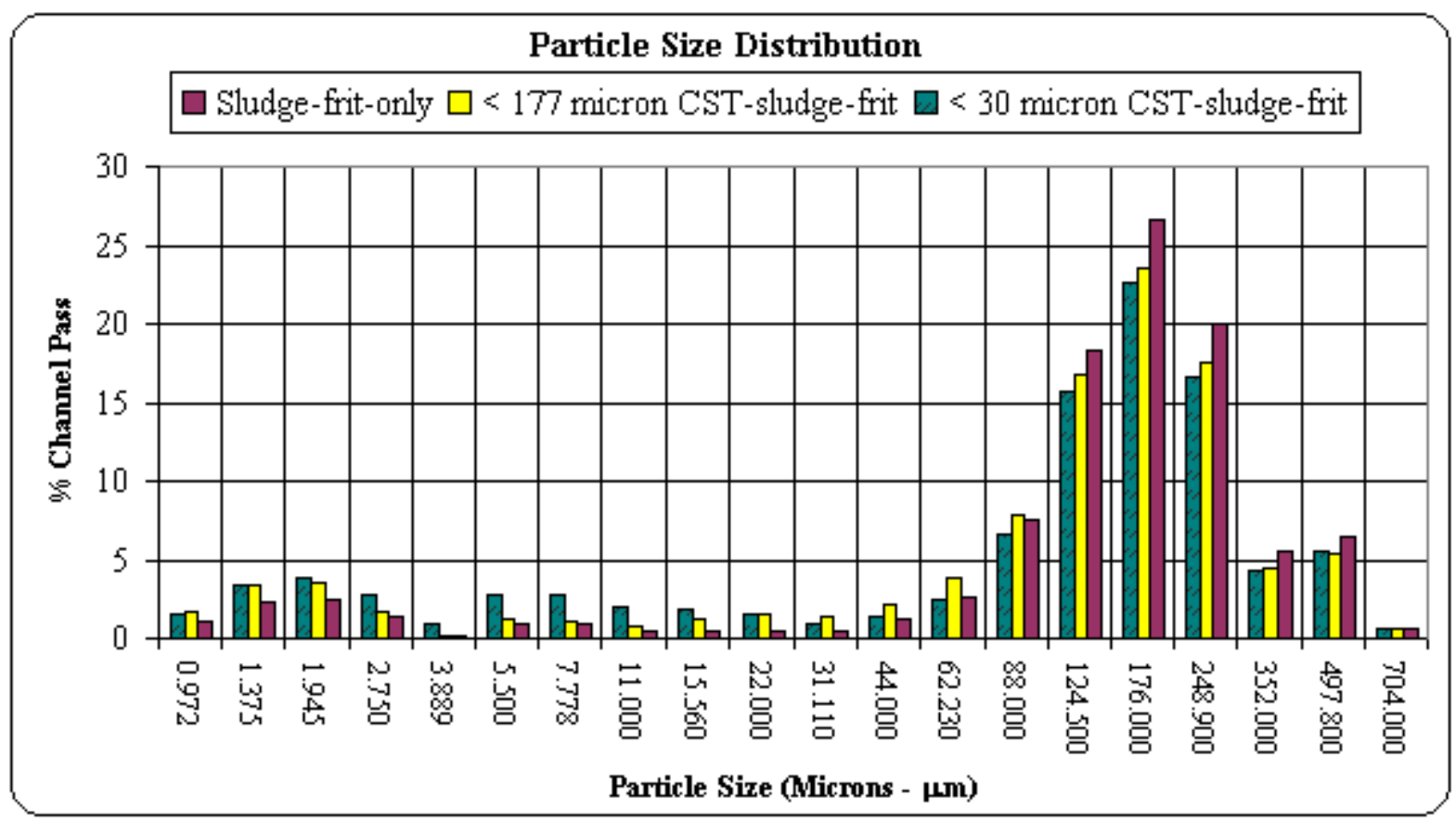

Rheology Results

The uncorrected rheograms for Sludge-frit-only slurries are shown in Figures 6 and 7. The uncorrected rheograms for $<177 \mu \mathrm{m}$ CST-sludge-frit slurries are shown in Figures 8 and 9. The uncorrected rheograms for $<30 \mu \mathrm{m}$ CST-sludge-frit slurries are shown in Figures 10 and 11. For each slurry, the rheograms obtained using the parallel plates yielded more viscous flow curves then were obtained with the concentric cylindrical geometry. The differences could be due to not correcting the flow curves, as discussed in the Rheology section above, as well as to other factors such as inertia, settling, etc.

The flow curves in Figures 6, 8, and 10 were such that the lower curve was the shear rate up flow curve and the top curve was the shear rate down flow curve for each slurry as labeled by its wt. $\%$ TS. The mechanism to produce a more viscous down curve was not investigated in this study or in reference 13. Inspection of Figures 6, 8, and 10 indicate that the up flow curves have a curvature, which, when fitted with a linear equation, would produce different results (yield stress and consistency) depending on the shear rate range chosen. It was decided that a common shear rate range (100 to $350 \mathrm{sec}^{-1}$ ) would be used for all the up curves and the curves fitted with the 
WSRC-TR-2001-00069

Page 17 of 35

Bingham Plastic model. In two cases the down curve was curve fitted for the $<30 \mu \mathrm{m}$ CSTsludge-frit, due to the Bingham model did not fit the data for the up curves. The Bingham Plastic yield stress and consistency for each flow curve are shown in Table 13. The individual flow curves (rheograms) are located in the Appendix.

Originally, the measurements using the RS150 were made for a shear rate of 0-400 $\mathrm{sec}^{-1}$. The basis for this original shear rate range was to closely match that of the RV20 data. The flow curves associated with this shear rate range are shown in the Appendix, Figures A-1 through A3. Review of these figures indicated that a common shear rate range could not be used for fitting the Bingham Plastic model to all the curves. It was decided to measure the rheology again and to increase the shear rate range to $1000 \mathrm{sec}^{-1}$. These results are shown in Figures 7, 9, and 11 and the resulting flow curves behave as expected, where the up curve and down curves almost overlay each other. For the maximum wt. \% TS flow curves, the return curve was typically much more viscous than the up curve, due to drying around the edges. The flow curves in Figure 7, Sludge-frit-only, exhibited a power law behavior in the lower shear rate ranges, but became linear after approximately $150 \mathrm{sec}^{-1}$. The flow curves in Figure 9, $<177 \mu \mathrm{m}$ CST-sludge-frit exhibited a power law behavior up to approximately $400 \mathrm{sec}^{-1}$. The flow curves in Figure 11, Tank 8/40 <30um CST, exhibited structural breakdown $\left(0-500 \mathrm{sec}^{-1}\right)$ and recovery of structure $\left(200-0 \mathrm{sec}^{-1}\right)$ and did not fit simplistic flow models such as the Bingham Plastic, Power Law, or Hershel-Bulkley models. The shear rate range of 300 to $1000 \mathrm{sec}^{-1}$ was used to fit the Bingham Plastic model and the results are shown in Table 13. The individual flow curves for the 0 to $1000 \sec ^{-1}$ are in the Appendix.

The $<30 \mu \mathrm{m}$ CST-sludge-frit slurries, shown in Figure 11, were more thixotropic (hysteresis) than the other slurries, at the lower end of the flow curves (shear rate $<450 \mathrm{sec}^{-1}$ ), when comparing the RS150 data. As stated above $<177 \mu \mathrm{m}$ CST-sludge-frit slurries and Sludge-fritonly slurries seemed to fit a power law fluid in the shear rate range of 0 to $450 \mathrm{sec}^{-1}$. Above the shear rate of $450 \mathrm{sec}^{-1}$, the up and down curves were fairly similar showing very little to no thixotropy for all the slurries. The $<30 \mu \mathrm{m}$ CST-sludge-frit slurries seemed to have a solids structure that broke down due to shearing and was not completely recovered when the shear was slowly removed. The reason for this thixotropic behavior could have been due to the particles becoming aligned in the direction of flow, hence the less viscous return flow curve. Based on this observation, the $<30 \mu \mathrm{m}$ CST-sludge-frit slurries behaved differently than the others slurries at lower shear rates. 
WSRC-TR-2001-00069

Page 18 of 35

TABLE 13. Bingham Plastic Model Parameters

\begin{tabular}{|c|c|c|c|c|c|c|c|}
\hline \multicolumn{8}{|c|}{ Sludge-Frit-Only } \\
\hline \multirow[b]{2}{*}{ wt. \% TS } & \multirow[b]{2}{*}{ wt. \% IS } & \multicolumn{3}{|c|}{ RV20 } & \multicolumn{3}{|c|}{ RS150 } \\
\hline & & $\begin{array}{l}\text { Yield Stress } \\
\left(\text { dynes } / \mathrm{cm}^{2}\right)\end{array}$ & $\begin{array}{c}\text { Consistency } \\
\text { (cP) }\end{array}$ & $\mathrm{R}^{2}$ & $\begin{array}{l}\text { Yield Stress } \\
\left(\text { dynes } / \mathrm{cm}^{2}\right)\end{array}$ & $\begin{array}{l}\text { Consistency } \\
\text { (cP) }\end{array}$ & $\mathrm{R}^{2}$ \\
\hline 39.2 & 35.0 & 94 & 8.7 & 0.9896 & 110 & 4.1 & 0.9966 \\
\hline 40.9 & 36.4 & 113 & 8.1 & 0.9844 & 155 & 5.6 & 0.9992 \\
\hline 43.3 & 38.6 & 161 & 8.9 & 0.9859 & 223 & 7.3 & 0.9994 \\
\hline 46.1 & 41.1 & 206 & 12.8 & 0.9949 & 295 & 8.3 & 0.9970 \\
\hline 47.7 & 42.7 & 247 & 20.2 & 0.9982 & 353 & 11.7 & 0.9974 \\
\hline 52.1 & 46.8 & 459 & 23.3 & 0.9850 & 722 & 29.4 & 0.9996 \\
\hline \multicolumn{8}{|c|}{$<177 \mu \mathrm{m}$ CST-Sludge-Frit } \\
\hline \multirow[b]{2}{*}{ wt. \% TS } & \multirow[b]{2}{*}{ wt. \% IS } & \multicolumn{3}{|c|}{ RV20 } & \multicolumn{3}{|c|}{ RS150 } \\
\hline & & $\begin{array}{l}\text { Yield Stress } \\
\left(\text { dynes } / \mathrm{cm}^{2}\right)\end{array}$ & $\begin{array}{c}\text { Consistency } \\
\text { (cP) }\end{array}$ & $\mathrm{R}^{2}$ & $\begin{array}{l}\text { Yield Stress } \\
\left(\text { dynes } / \mathrm{cm}^{2}\right)\end{array}$ & $\begin{array}{c}\text { Consistency } \\
\text { (cP) }\end{array}$ & $\mathrm{R}^{2}$ \\
\hline 39.3 & 35.4 & 120 & 13.90 & 0.9937 & 203 & 1.5 & 0.8482 \\
\hline 41.4 & 37.3 & 150 & 18.30 & 0.9842 & 242 & 3.7 & 0.9675 \\
\hline 43.8 & 38.8 & 203 & 16.00 & 0.9888 & 343 & 6.5 & 0.9667 \\
\hline 45.8 & 41.3 & 251 & 19.80 & 0.9980 & 428 & 8.8 & 0.9655 \\
\hline 48.4 & 43.8 & 328 & 28.10 & 0.9970 & 555 & 16.0 & 0.9986 \\
\hline 52.2 & 46.8 & 751 & 56.70 & 0.9937 & 994 & 34.5 & 0.9964 \\
\hline \multicolumn{8}{|c|}{$<30 \mu \mathrm{m}$ CST-Sludge-Frit } \\
\hline \multirow[b]{2}{*}{ wt. \% TS } & \multirow[b]{2}{*}{ wt. \% IS } & \multicolumn{3}{|c|}{ RV20 } & \multicolumn{3}{|c|}{ RS150 } \\
\hline & & $\begin{array}{l}\text { Yield Stress } \\
\left(\text { dynes } / \mathrm{cm}^{2}\right)\end{array}$ & $\begin{array}{c}\text { Consistency } \\
(\mathrm{cP})\end{array}$ & $\mathrm{R}^{2}$ & $\begin{array}{l}\text { Yield Stress } \\
\left(\text { dynes } / \mathrm{cm}^{2}\right)\end{array}$ & $\begin{array}{c}\text { Consistency } \\
(\mathrm{cP})\end{array}$ & $\mathrm{R}^{2}$ \\
\hline 39.1 & 34.6 & 98 & 5.2 & 0.9296 & 106 & 7.8 & 0.9986 \\
\hline 41.0 & 36.2 & 108 & 8.8 & 0.9850 & 138 & 8.2 & 0.9982 \\
\hline 43.2 & 38.6 & 172 & 6.4 & 0.9423 & 194 & 9.4 & 0.9994 \\
\hline 45.2 & 40.0 & 193 & 13.8 & 0.9428 & 294 & 12.6 & 0.9970 \\
\hline 47.3 & 41.9 & 273 & 15.6 & 0.9882 & 429 & 16.5 & 0.9968 \\
\hline 48.9 & 43.4 & 400 & 22.9 & 0.9960 & 576 & 19.8 & 0.9978 \\
\hline
\end{tabular}


WSRC-TR-2001-00069

Page 19 of 35

FIGURE 6. RV20 Rheograms, Sludge-Frit-Only

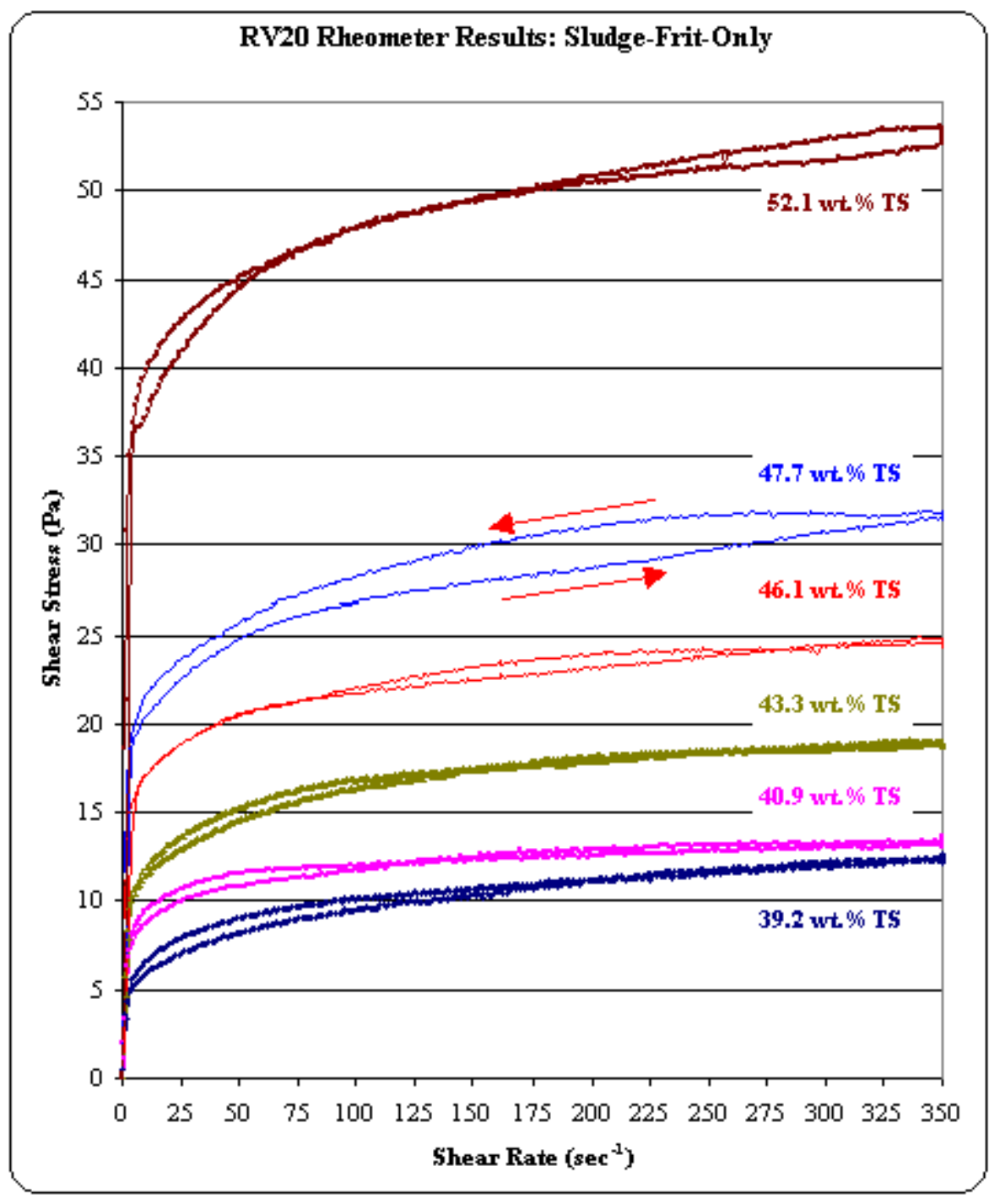

FIGURE 7. RS150 Rheograms, Sludge-Frit-Only

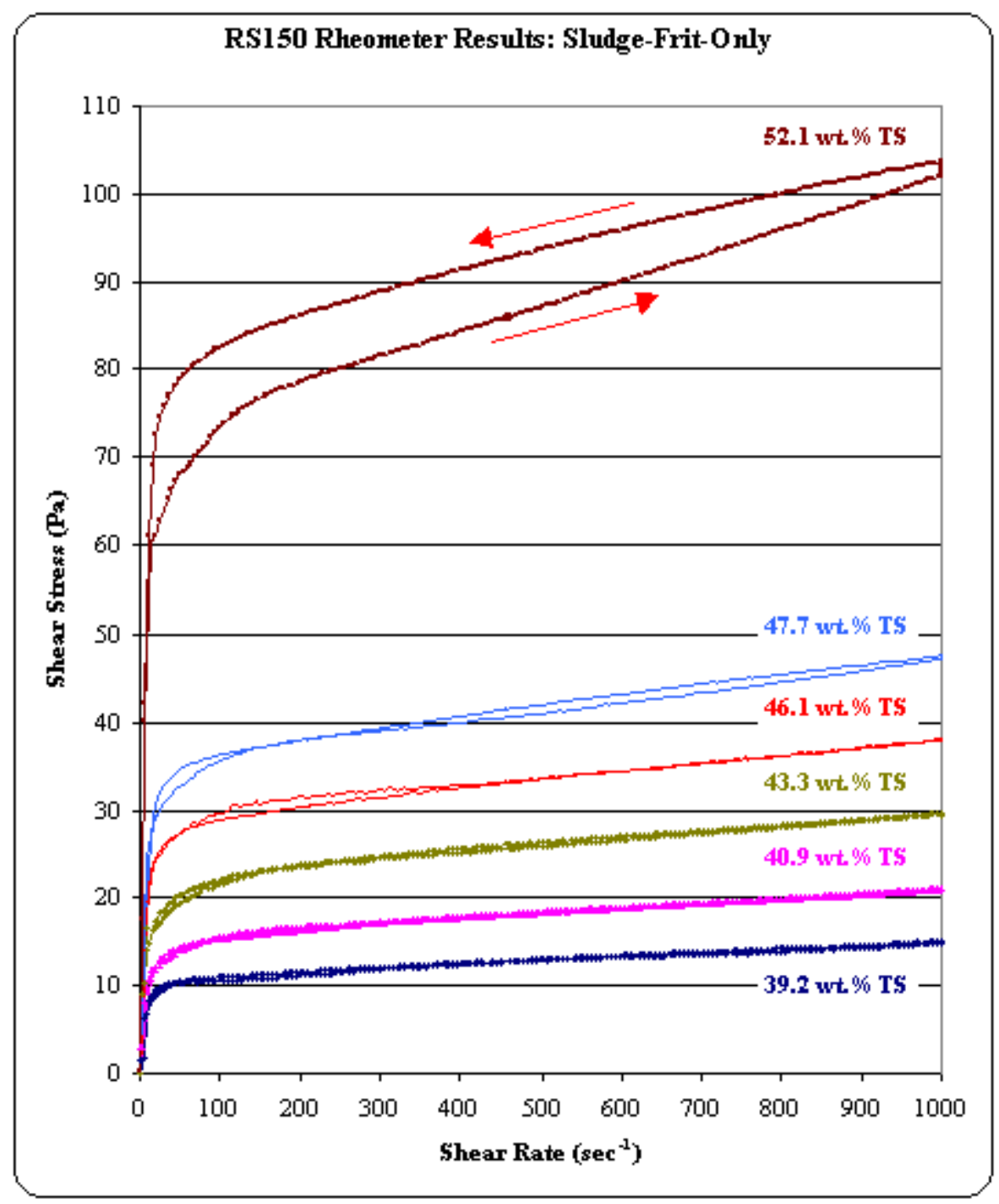


FIGURE 8. RV20 Rheograms - < $177 \mu \mathrm{m}$ CST-Sludge-Frit

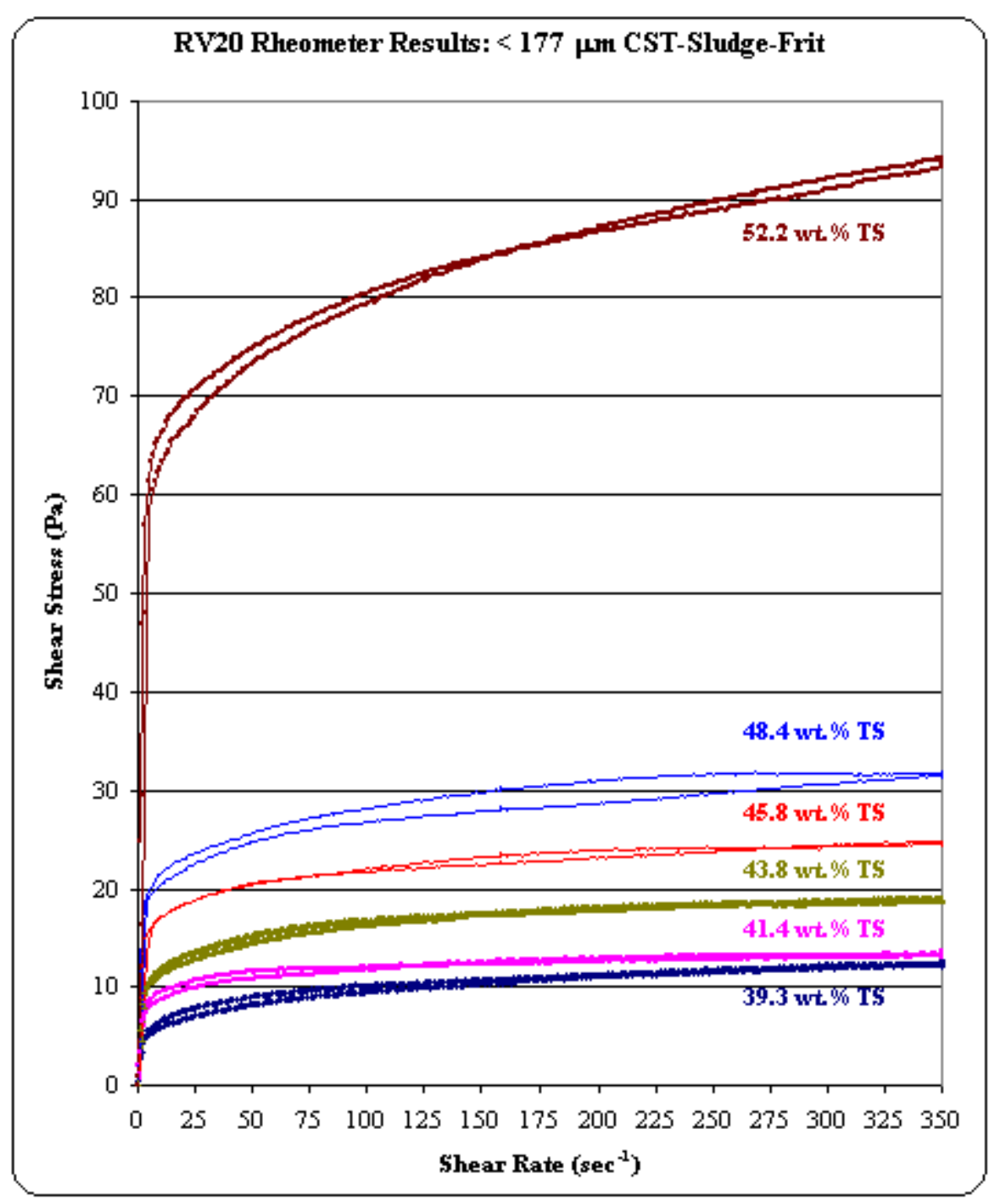

FIGURE 9. RS150 Rheograms - < $177 \mu \mathrm{m}$ CST-Sludge-Frit

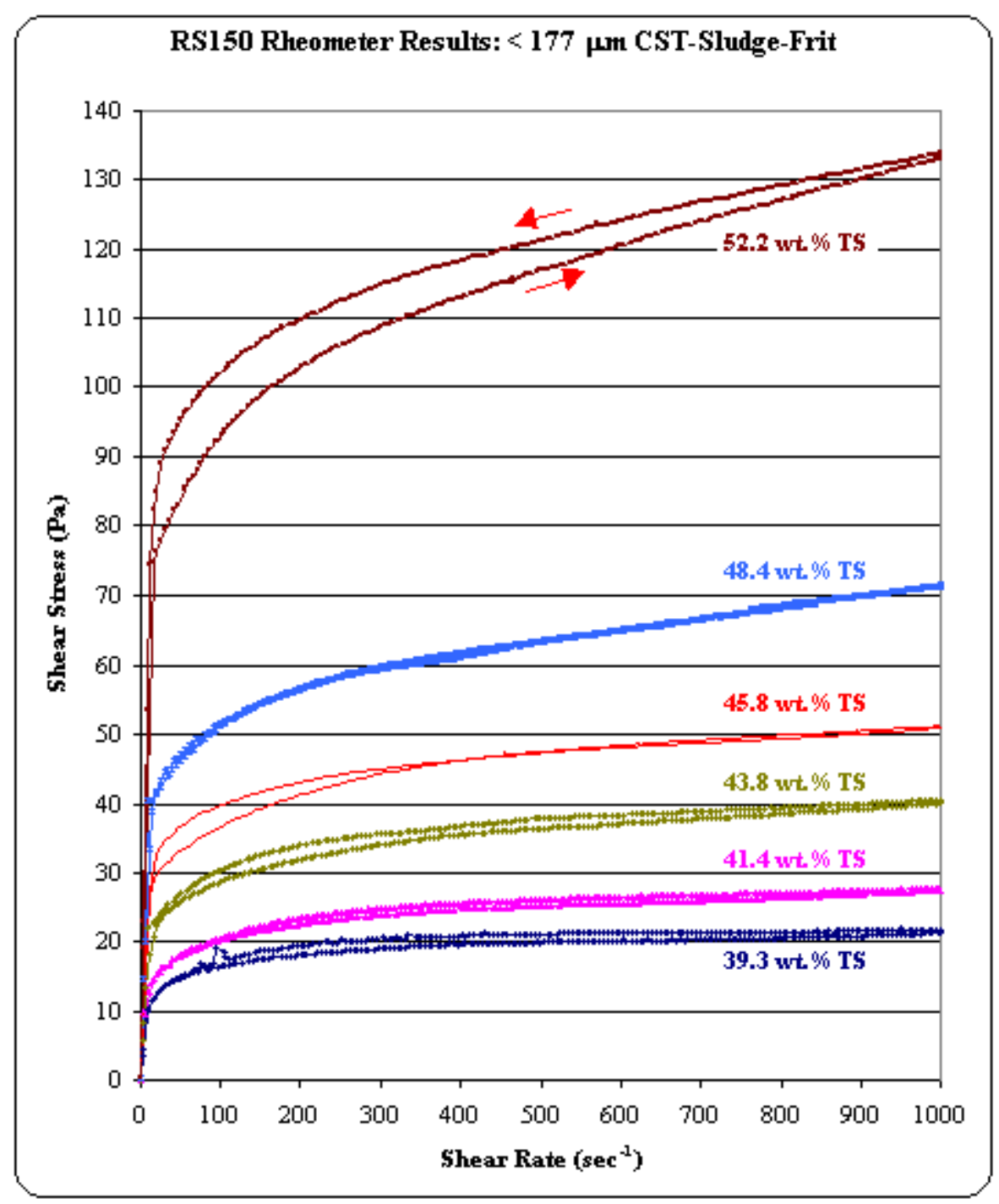


FIGURE 10. RV20 Rheograms - <30 $\mu \mathrm{m}$ CST-Sludge-Frit

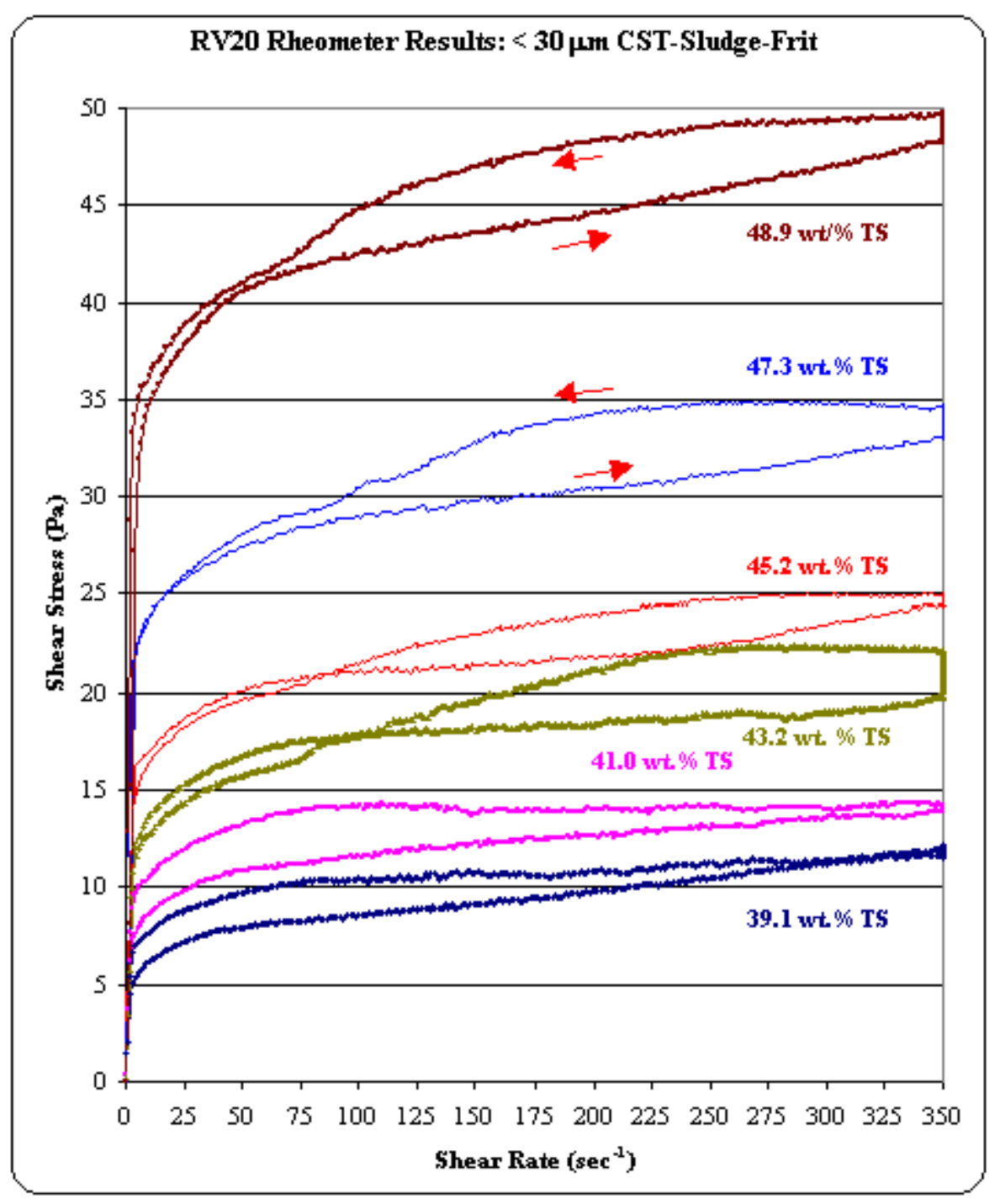

FIGURE 11. RS150 Rheograms - < $30 \mu \mathrm{m}$ CST-Sludge-Frit

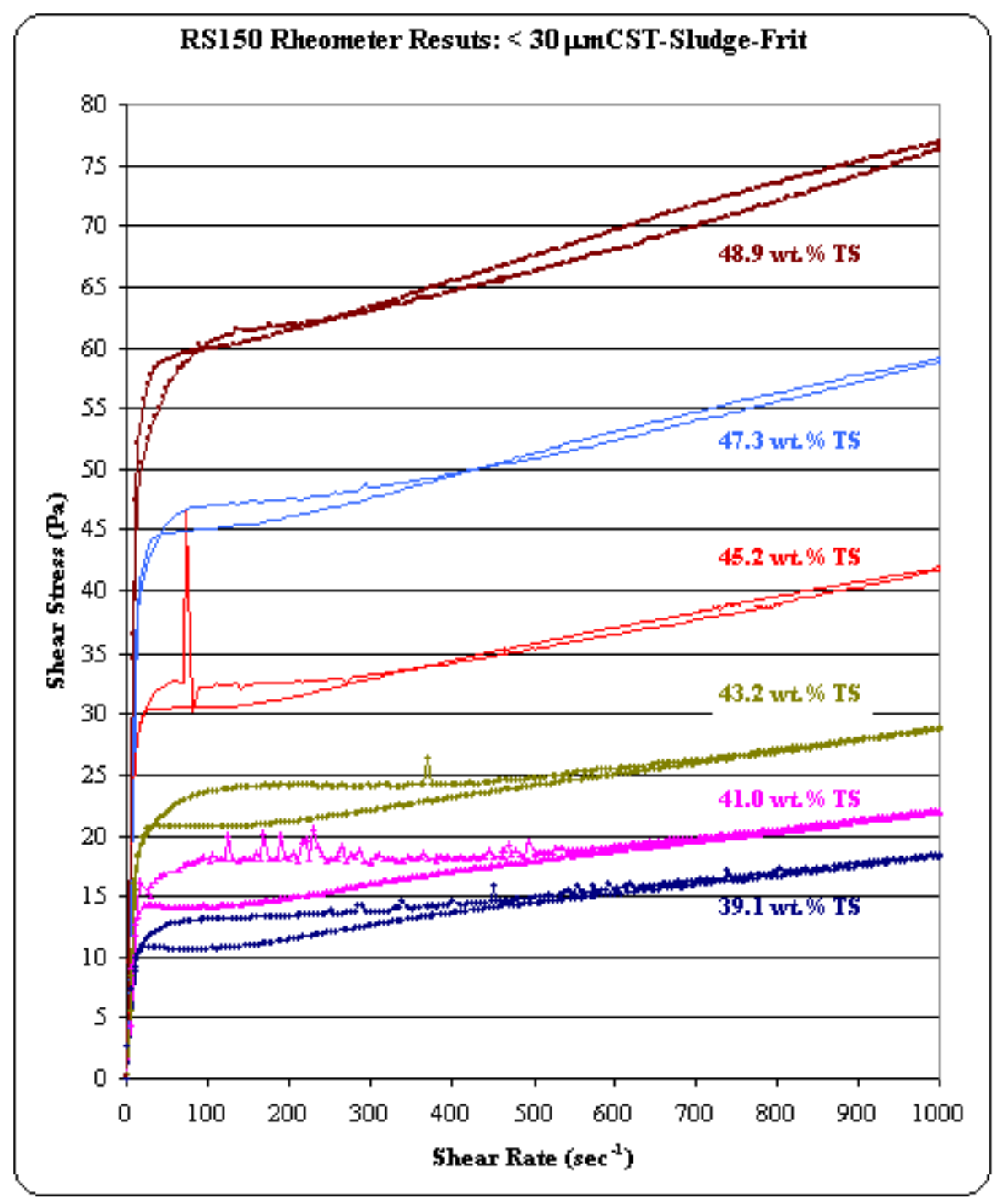


WSRC-TR-2001-00069

Page 22 of 35

The Bingham Plastic parameters in Table 13 were fit to equations [3] and [4] for both wt. \% TS and wt. \% IS with the results shown in Table 14. The results obtained using these fitted variables for equations [3] and [4] are only applicable for the range in which they were fitted.

Extrapolating past the maximum value used to fit the curve is not recommended, since there is no data to support this. Additionally, some of the calculated $\mathrm{C}_{\max }$ values were physically unrealistic, having values close to or exceeding $100 \mathrm{wt}$. \% solids. Equations [3] and [4] were modified to equation [5], which allowed the value of the modeled parameter at $\mathrm{C}=0$ to be a new model constant (not forced to be one), thus fitting the actual data points better. The constant $A_{i}$ has the units of dynes $/ \mathrm{cm}^{2}$ or $\mathrm{cP}$. Again, this curve fit is only applicable to the range in which the data was fitted.

$$
\tau_{o}\{\text { or } \eta\}=A_{i} \frac{\exp ^{b i^{* *} C}}{\left(1-C / C_{\max , i}\right)}
$$

Equation [5] was applied to the RS150 data set for the $<177 \mu \mathrm{m}$ CST-sludge-frit and the results are shown in Table 14. Because equation [5] has an additional constant compared with equations [3] and [4], the $R^{2}$ value will be closer to one for all cases (except if $A_{i}=1$, then the $R^{2}$ would be the same). If the calculated $\mathrm{C}_{\max }$ values are interpreted as the maximum solids concentration, using equation [5] for the $<177 \mu \mathrm{m}$ CST-sludge-frit provides a physically realistic fit. As stated in Shook and Roco, "Of course, since concentration is not the only relevant parameter, there is no a priori 'best' functional form of the relationship."

The results in Table 14 are shown graphically in Figures 12 through 19. Additionally, all the graphs have the upper DWPF design limit of 150 dynes $/ \mathrm{cm}^{2}$ shown on the yield stress figures and both DWPF consistency design limits are shown in the consistency figures. Observations from the RV20 are in Table 15 and from the RS150 in Table 16. 
WSRC-TR-2001-00069

Page 23 of 35

TABLE 14. Curves Fitted To Bingham Plastic Model Parameter to Wt. \% Solids

\begin{tabular}{|c|c|c|c|c|c|c|c|}
\hline \multicolumn{8}{|c|}{ Sludge-Frit-Only } \\
\hline & & \multicolumn{3}{|c|}{ Curve Fit - Total Solids } & \multicolumn{3}{|c|}{ Curve Fit - Insoluble Solids } \\
\hline & & $\begin{array}{c}\mathrm{b}_{\mathrm{TS}} \\
(\text { wt. } \% \mathrm{TS})^{-1}\end{array}$ & $\begin{array}{c}\mathrm{c}_{\max , \mathrm{TS}} \\
\text { (wt. \% TS) }\end{array}$ & $\mathrm{R}^{2}$ & $\begin{array}{c}\mathrm{b}_{\mathrm{IS}, \mathrm{TS}} \\
(\text { wt. \% IS })^{-1}\end{array}$ & $\begin{array}{c}\mathrm{c}_{\max , I S} \\
\text { (wt. \% IS) }\end{array}$ & $\mathrm{R}^{2}$ \\
\hline \multirow{2}{*}{ RV20 } & Yield Stress (dynes/cm²) & 0.0989 & 84.08 & 0.9964 & 0.1156 & 92.11 & 0.9965 \\
\hline & Consistency (cP) & 0.0310 & 65.77 & 0.8737 & 0.0360 & 60.24 & 0.8754 \\
\hline \multirow{2}{*}{ RS150 } & Yield Stress (dynes/cm²) & 0.1010 & 71.27 & 0.9958 & 0.1161 & 68.76 & 0.9953 \\
\hline & Consistency (cP) & 0.0083 & 55.00 & 0.9961 & 0.0103 & 49.55 & 0.9961 \\
\hline \multicolumn{8}{|c|}{$<177 \mu \mathrm{m}$ CST-Sludge-Frit } \\
\hline & & \multicolumn{3}{|c|}{ Curve Fit - Total Solids } & \multicolumn{3}{|c|}{ Curve Fit - Insoluble Solids } \\
\hline & & $\begin{array}{c}\mathrm{b}_{\mathrm{TS}} \\
(\text { wt. } \% \mathrm{TS})^{-1}\end{array}$ & $\begin{array}{c}\mathrm{c}_{\max , \mathrm{TS}} \\
\text { (wt. \% TS) }\end{array}$ & $\mathrm{R}^{2}$ & $\begin{array}{c}\mathrm{b}_{\mathrm{IS}} \\
(\text { wt. } \% \text { IS })^{-1}\end{array}$ & $\begin{array}{c}\mathrm{c}_{\max , I S} \\
\text { (wt. \% IS) }\end{array}$ & $\mathrm{R}^{2}$ \\
\hline \multirow{2}{*}{ RV20 } & Yield Stress (dynes/cm²) & 0.0901 & 61.31 & 0.9868 & 0.0976 & 53.77 & 0.9746 \\
\hline & Consistency $(\mathrm{cP})$ & 0.0330 & 57.96 & 0.9724 & 0.0353 & 51.56 & 0.9665 \\
\hline \multirow{2}{*}{ RS150 } & Yield Stress $\left(\right.$ dynes $\left./ \mathrm{cm}^{2}\right)$ & 0.1296 & 439.75 & 0.9935 & 0.1398 & 162.27 & 0.9821 \\
\hline & Consistency $(\mathrm{cP})$ & 0.0081 & 54.58 & 0.9657 & 0.0076 & 48.75 & 0.9726 \\
\hline \multirow{2}{*}{ RS150 } & Modified Equation [5] & 0.0524 & 61.15 & 0.9979 & 0.0330 & 52.114 & 0.9937 \\
\hline & Yield Stress (dynes/cm²) & \multicolumn{3}{|c|}{$\mathrm{A}=9.416\left(\right.$ dynes $\left./ \mathrm{cm}^{2}\right)$} & \multicolumn{3}{|c|}{$\mathrm{A}=21.755\left(\right.$ dynes $\left./ \mathrm{cm}^{2}\right)$} \\
\hline \multicolumn{8}{|c|}{$<30 \mu \mathrm{m}$ CST-Sludge-Frit } \\
\hline & & \multicolumn{3}{|c|}{ Curve Fit - Total Solids } & \multicolumn{3}{|c|}{ Curve Fit - Insoluble Solids } \\
\hline & & $\begin{array}{c}\mathrm{b}_{\mathrm{TS}} \\
(\text { wt. \% TS })^{-1}\end{array}$ & $\begin{array}{c}\mathrm{c}_{\max , \mathrm{TS}} \\
\text { (wt. \% TS) }\end{array}$ & $\mathrm{R}^{2}$ & $\begin{array}{c}\mathrm{b}_{\mathrm{IS}} \\
(\text { wt. \% IS })^{-1}\end{array}$ & $\begin{array}{c}\mathrm{c}_{\max , \text { IS }} \\
\text { (wt. \% IS) }\end{array}$ & $\mathrm{R}^{2}$ \\
\hline \multirow{2}{*}{ RV20 } & Yield Stress (dynes/cm²) & 0.0852 & 58.61 & 0.9799 & 0.0973 & 52.50 & 0.9818 \\
\hline & Consistency (cP) & 0.0119 & 53.04 & 0.9317 & 0.0140 & 47.12 & 0.9281 \\
\hline \multirow{2}{*}{ RS150 } & Yield Stress (dynes/cm²) & 0.0903 & 57.00 & 0.9981 & 0.1030 & 50.96 & 0.9977 \\
\hline & Consistency (cP) & 0.0203 & 56.50 & 0.9894 & 0.0235 & 50.31 & 0.9882 \\
\hline
\end{tabular}


WSRC-TR-2001-00069

Page 24 of 35

TABLE 15. Observations From RV20

\begin{tabular}{|c|c|c|}
\hline & Sludge-Frit-Only & Figures \\
\hline 1 & The yield stress starts to exceed the DWPF upper design limit around $43 \mathrm{wt} . \%$ TS and $39 \mathrm{wt} . \%$ IS. & 12,14 \\
\hline \multirow[t]{2}{*}{2} & $\begin{array}{l}\text { The consistency is below the DWPF lower design limit around } 43 \text { wt. \% TS and } 39 \text { wt. \% IS. The } \\
\text { last consistency data point seems to be very low. }\end{array}$ & 16,18 \\
\hline & $<177 \mu \mathrm{m}$ CST-Sludge-Frit & \\
\hline 1 & The yield stress exceeds the DWPF upper design limit at 42 wt. $\%$ TS and 39 wt. $\%$ IS. & 12,14 \\
\hline \multirow[t]{2}{*}{2} & The consistency exceeds the DWPF upper design limit around $50 \mathrm{wt} . \%$ TS and $45 \mathrm{wt} . \%$ IS. & 16,18 \\
\hline & $<30 \mu \mathrm{m}$ CST-Sludge-Frit & \\
\hline 1 & The yield stress exceeds the DWPF upper design limit around $43 \mathrm{wt} . \%$ TS and $39 \mathrm{wt} . \%$ IS. & 12,14 \\
\hline \multirow[t]{2}{*}{2} & The consistency is below the DWPF design limit around $43 \mathrm{wt} . \%$ TS and $38 \mathrm{wt} . \%$ IS. & 16,18 \\
\hline & Comparing Sludge-Frit-Only to $<177 \mu \mathrm{m}$ CST-Sludge-Frit & \\
\hline 1 & $\begin{array}{l}\text { The yield stress for }<177 \mu \mathrm{m} \text { CST-sludge-frit is greater than that of the Sludge-frit-only at any } \\
\text { given wt. } \% \text { solids and this difference becomes larger as the wt. \% solids increases. }\end{array}$ & 12,14 \\
\hline \multirow[t]{2}{*}{2} & $\begin{array}{l}\text { The consistency for }<177 \mu \mathrm{m} \text { CST-sludge-frit is greater than that of the Sludge-frit-only at any } \\
\text { given wt. } \% \text {. }\end{array}$ & 16,18 \\
\hline & Comparing Sludge-Frit-Only to $<30 \mu \mathrm{m}$ CST-Sludge-Frit & \\
\hline 1 & $\begin{array}{l}\text { The yield stress for }<30 \mu \mathrm{m} \text { CST-sludge-frit starts to exceed the yield stress of the Sludge-frit-only } \\
\text { at approximately } 43 \mathrm{wt} . \% \mathrm{TS} \text { and } 38 \mathrm{wt} . \% \text { IS and this difference becomes larger as the wt. } \% \\
\text { solids increases. }\end{array}$ & 12,14 \\
\hline \multirow[t]{2}{*}{2} & $\begin{array}{l}\text { The consistency of the }<30 \mu \mathrm{m} \text { CST-sludge-frit starts to exceed the consistency of the Sludge-frit- } \\
\text { only at } 47 \mathrm{wt} . \% \mathrm{TS} \text { and } 41 \mathrm{wt} \text { \% IS. If the last data point for the Sludge-frit-only is ignored, the } \\
\text { consistency for both of these sludges is comparable. }\end{array}$ & 16,18 \\
\hline & Comparing $<177 \mu \mathrm{m}$ CST-Sludge-Frit to $<30 \mu \mathrm{m}$ CST-Sludge-Frit & \\
\hline 1 & $\begin{array}{l}\text { The yield stress of the }<30 \mu \mathrm{m} \text { CST-sludge-frit starts to exceed the }<177 \mu \mathrm{m} \text { CST-sludge-frit } \\
\text { around } 42 \text { wt. \% IS. }\end{array}$ & 12,14 \\
\hline 2 & $\begin{array}{l}\text { The consistency of the }<30 \mu \mathrm{m} \text { CST-sludge-frit is smaller than the consistency of the } \\
<177 \mu \mathrm{m} \text { CST given any wt. } \% \text {. }\end{array}$ & 16,18 \\
\hline
\end{tabular}


WSRC-TR-2001-00069

Page 25 of 35

\section{TABLE 16. Observations From RS150}

\begin{tabular}{|c|c|c|}
\hline & Sludge-Frit-Only & Figures \\
\hline 1 & The yield stress starts to exceed the DWPF design limit around $41 \mathrm{wt}$ \% TS and $36 \mathrm{wt}$. \% IS. & 13,15 \\
\hline \multirow[t]{2}{*}{2} & The consistency is below the DWPF design limit around 47 wt. $\%$ TS and 42 wt. $\%$ IS. & 17,19 \\
\hline & $<177 \mu \mathrm{m}$ CST-Sludge-Frit & \\
\hline 1 & The yield stress always exceeds the DWPF design limit. & 13,15 \\
\hline 2 & The yield stress for $<177 \mu \mathrm{m}$ CST-sludge-frit parallels the Sludge-frit-only. & 13,15 \\
\hline 3 & Equation [5] fits the yield stress data better than equation [3]. & 13,15 \\
\hline 4 & The consistency data is below the DWPF design limit around $47 \mathrm{wt.} \%$ TS and $42 \mathrm{wt} . \%$ IS. & 17,19 \\
\hline \multirow[t]{2}{*}{5} & $\begin{array}{l}\text { Equation [4] over-estimates the consistency at the lower wt. \% TS and IS. Use of equation [5] } \\
\text { would have yielded a better fit. }\end{array}$ & 17,19 \\
\hline & $<30 \mu \mathrm{m}$ CST-Sludge-Frit & \\
\hline 1 & The yield stress exceeds the DWPF d & 13,15 \\
\hline \multirow[t]{2}{*}{2} & The consistency is below the DWPF design limit around $43 \mathrm{wt} . \%$ TS and $38 \mathrm{wt} . \%$ IS. & 17,19 \\
\hline & Comparing Sludge-Frit-Only to $<177 \mu \mathrm{m}$ CST-Sludge-Frit & \\
\hline 1 & $\begin{array}{l}\text { The yield stress for }<177 \mu \mathrm{m} \text { CST-sludge-frit is greater than that of the Sludge-frit-only at any } \\
\text { given wt. \% solids and the difference becomes larger as the wt. \% solids increases. The DWPF } \\
\text { upper design limit is always exceeded. }\end{array}$ & 13,15 \\
\hline \multirow[t]{2}{*}{2} & $\begin{array}{l}\text { The consistency for }<177 \mu \mathrm{m} \text { CST-sludge-frit is smaller than that of the Sludge-frit-only when } \\
\text { the wt. } \% \text { TS }<46 \% \text { and wt. } \% \text { IS }<44 \% \text {. After that, the }<177 \mu \mathrm{m} \text { CST-sludge-frit is greater than } \\
\text { the Sludge-frit-only. Overall, the two curves are about the same. }\end{array}$ & 17,19 \\
\hline & Comparing Sludge-Frit-Only to $<30 \mu \mathrm{m}$ CST-Sludge-Frit & \\
\hline 1 & $\begin{array}{l}\text { The yield stress for }<30 \mu \mathrm{m} \text { CST-sludge-frit exceeds the yield stress of the Sludge-frit-only at } \\
\text { approximately } 43 \text { wt. } \% \text { TS and } 38 \text { wt. } \% \text { IS. }\end{array}$ & 13,15 \\
\hline \multirow[t]{2}{*}{2} & The consistency of the $<30 \mu \mathrm{m}$ CST-sludge-frit always exceeds the Sludge-frit-only consistency. & 17,19 \\
\hline & T-Sludge-Frit & \\
\hline 1 & $\begin{array}{l}\text { The yield stress of the }<30 \mu \mathrm{m} \text { CST-sludge-frit never exceeds the yield stress of the }<177 \mu \mathrm{m} \\
\text { CST-sludge-frit. The wt. } \% \text { IS curves fitted with equation [5] shows that yield stress for }<30 \mu \mathrm{m} \\
\text { CST-sludge-frit exceeds the }<177 \mu \mathrm{m} \text { CST-sludge-frit at } 43 \mathrm{wt} \text {. \% IS. }\end{array}$ & 13,15 \\
\hline 2 & $\begin{array}{l}\text { The consistency of the }<30 \mu \mathrm{m} \text { CST-sludge-frit was greater than the consistency of the }<177 \mu \mathrm{m} \\
\text { CST-sludge-frit given any wt. } \% \text {. }\end{array}$ & 17,19 \\
\hline 3 & $\begin{array}{l}\text { The }<30 \mu \mathrm{m} \text { CST-sludge-frit yield stress raises increases faster than the }<177 \mu \mathrm{m} \text { CST-sludge-frit } \\
\text { as the wt. } \% \text { TS or IS increases. }\end{array}$ & 13,15 \\
\hline
\end{tabular}


FIGURE 12: Yield Stress versus Wt. \% TS - RV20

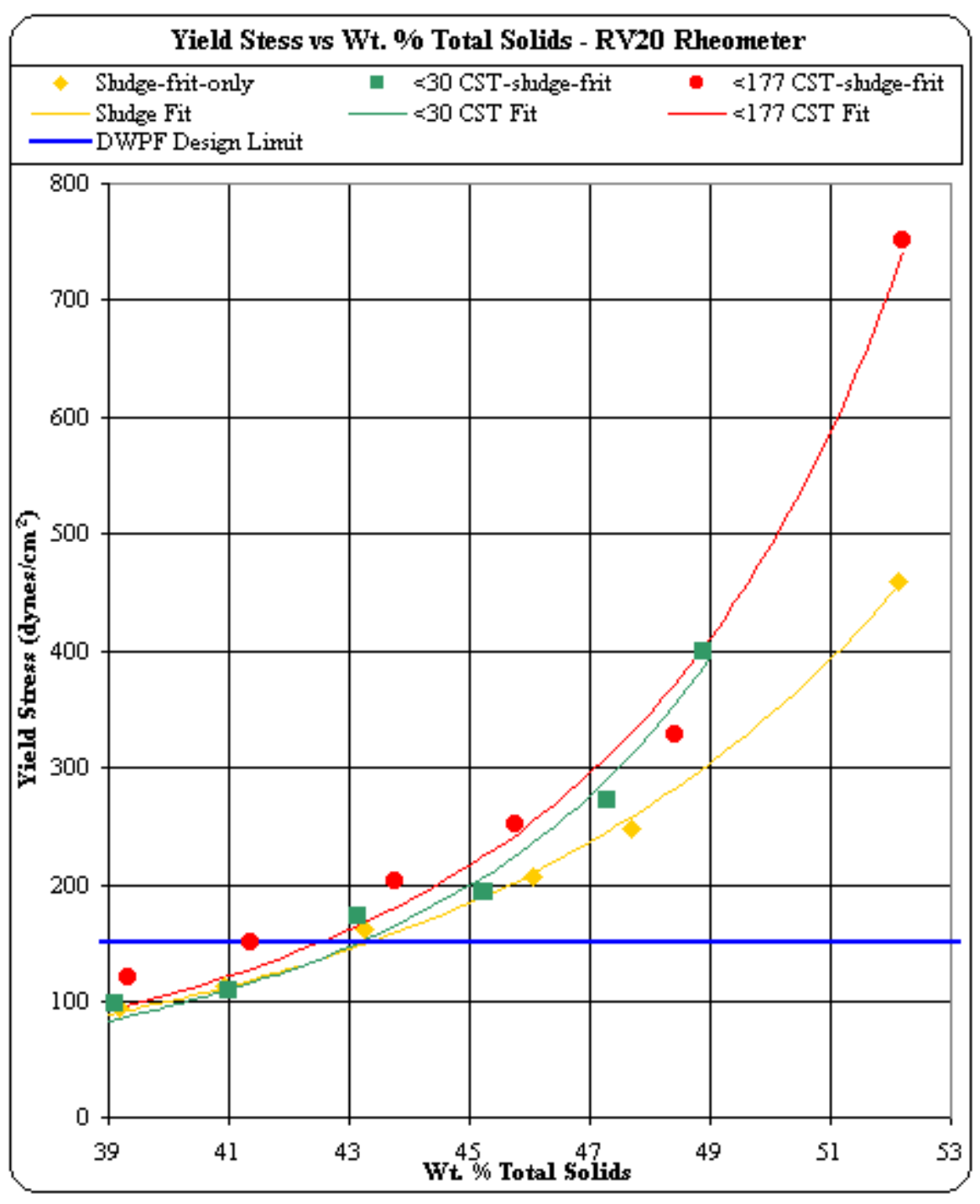

FIGURE 13: Yield Stress versus Wt. \% TS - RS150

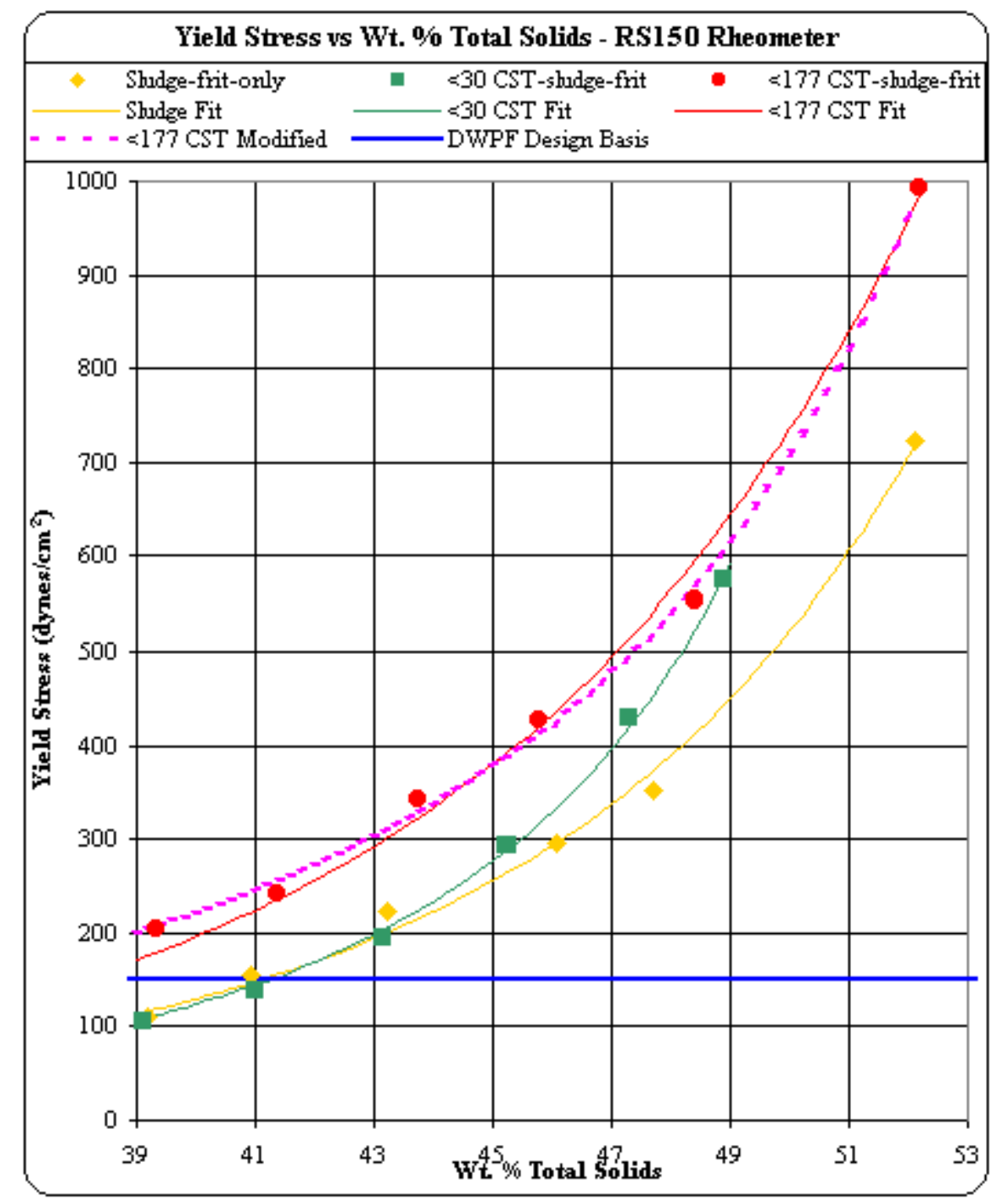


WSRC-TR-2001-00069

FIGURE 14. Yield Stress versus Wt. \% IS - RV20

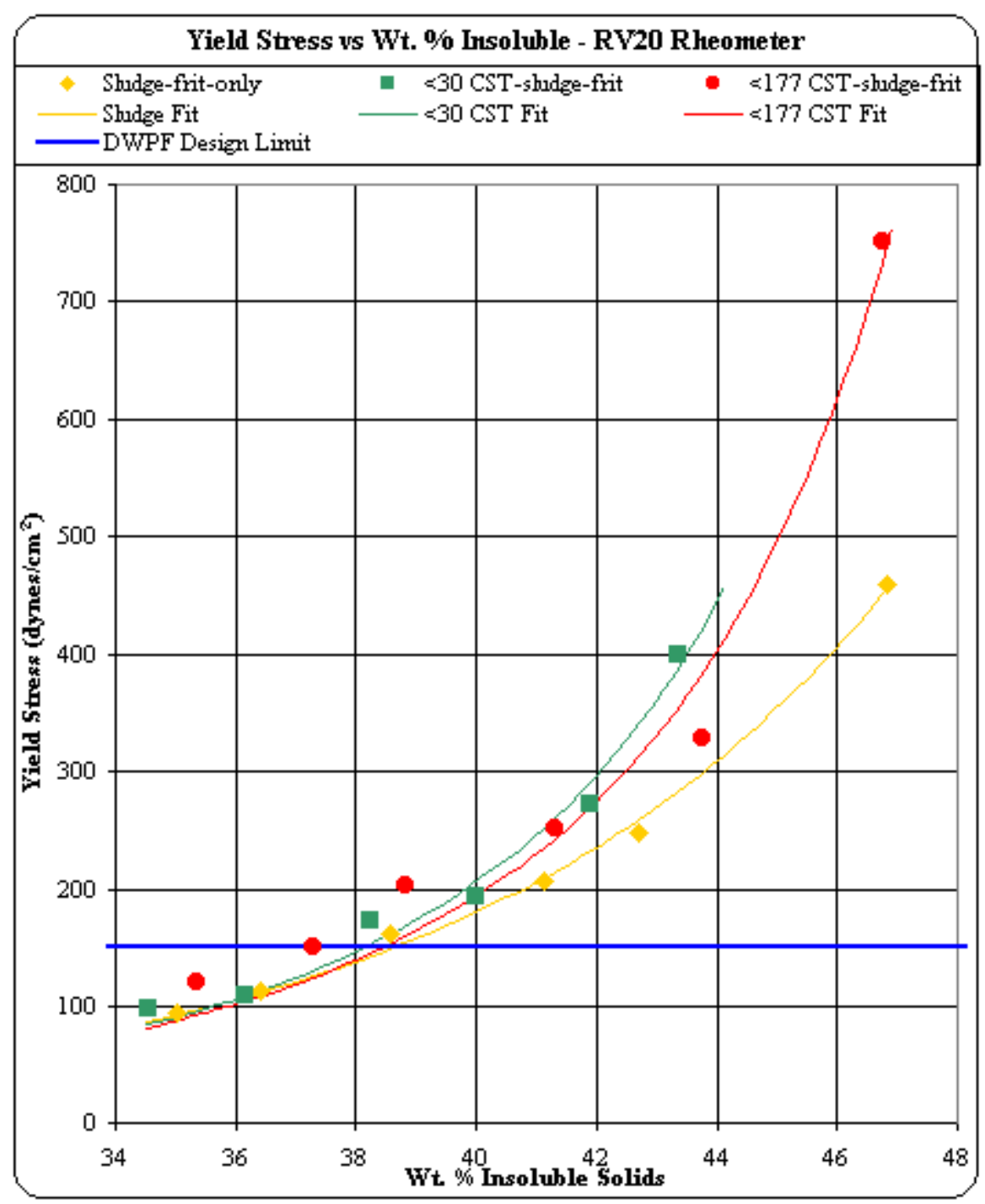

FIGURE 15. Yield Stress versus Wt. \% IS - RS 150

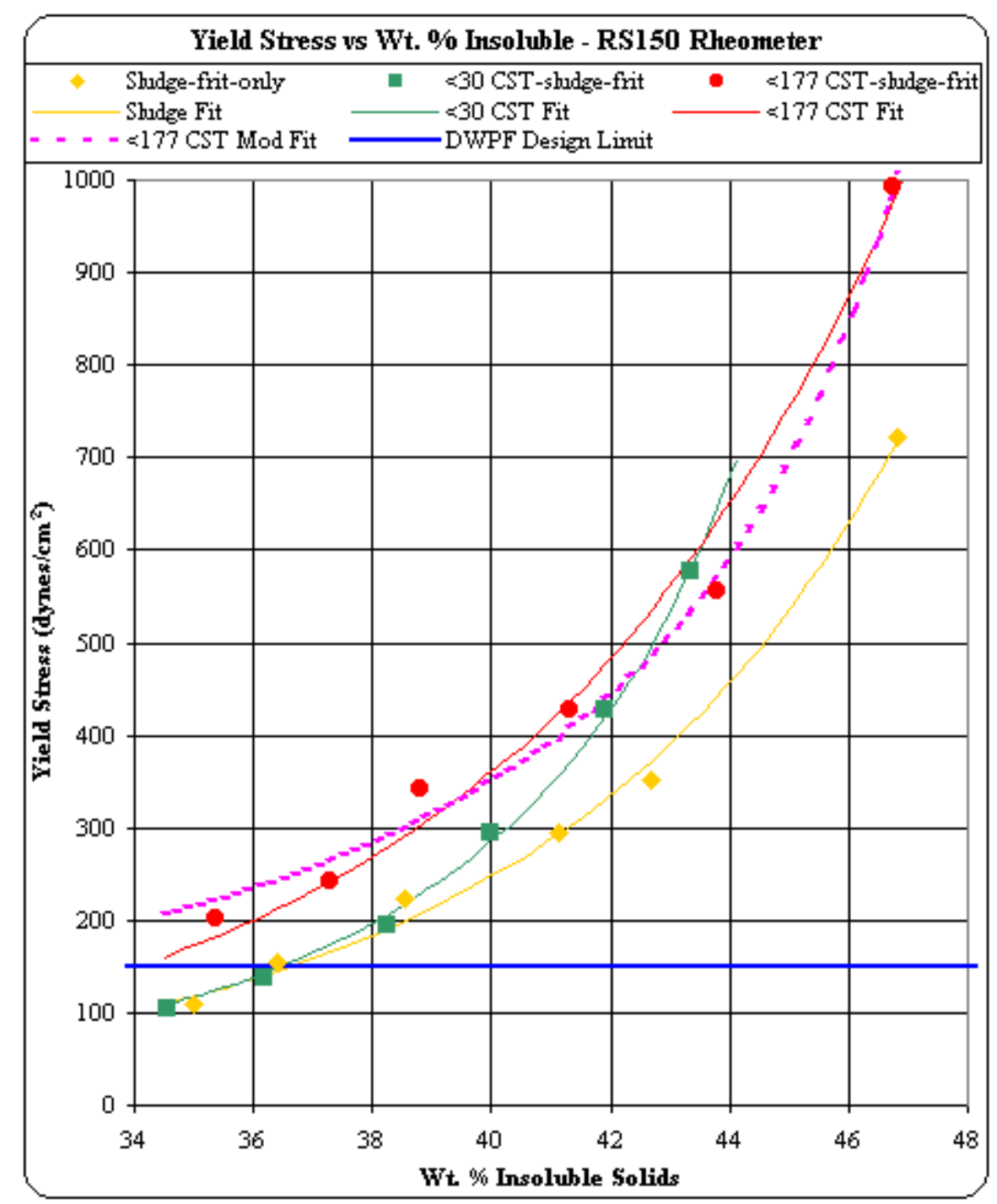


FIGURE 16. Consistency versus Wt. \% TS - RV20

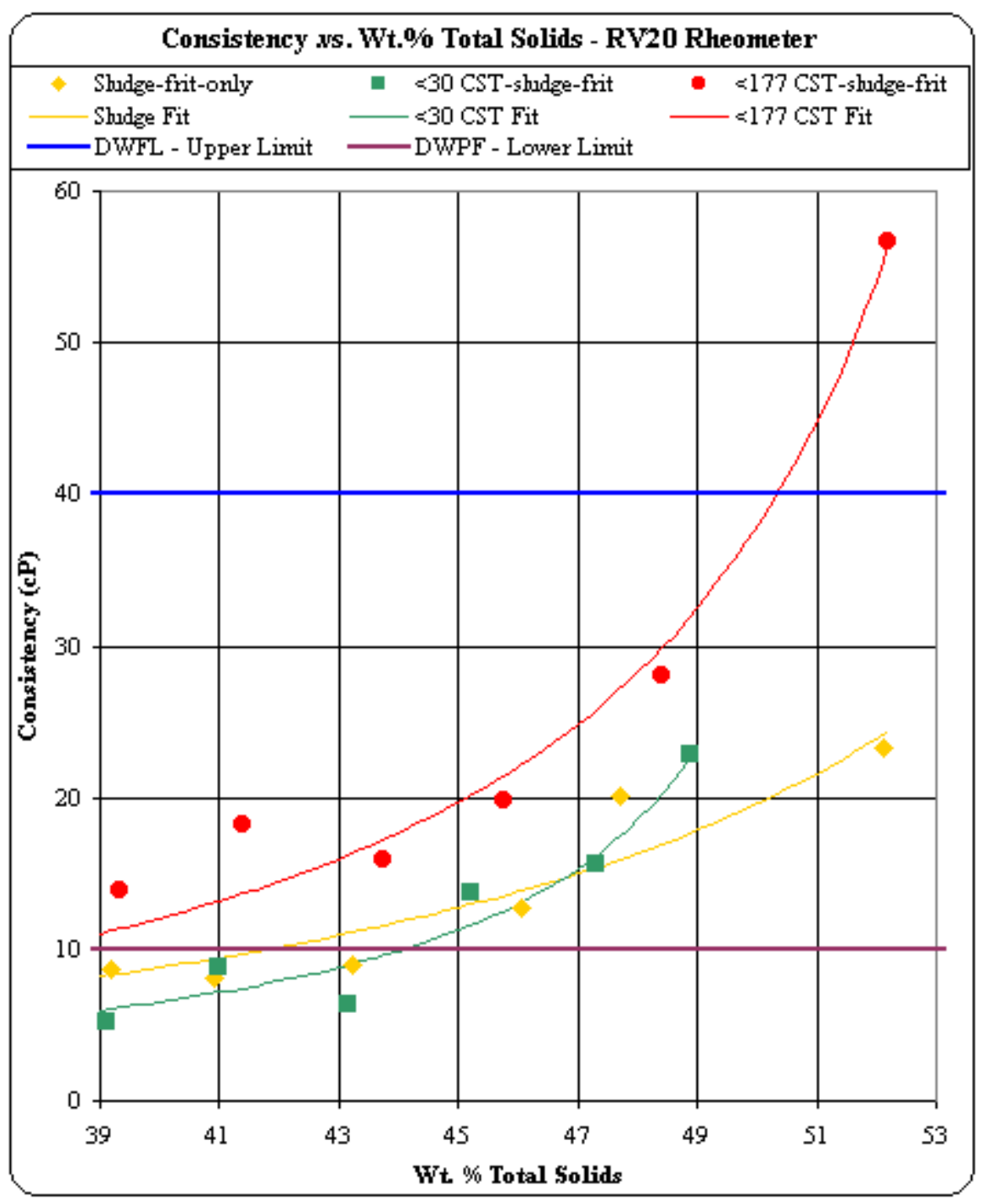

FIGURE 17. Consistency versus Wt. \% TS - RS150

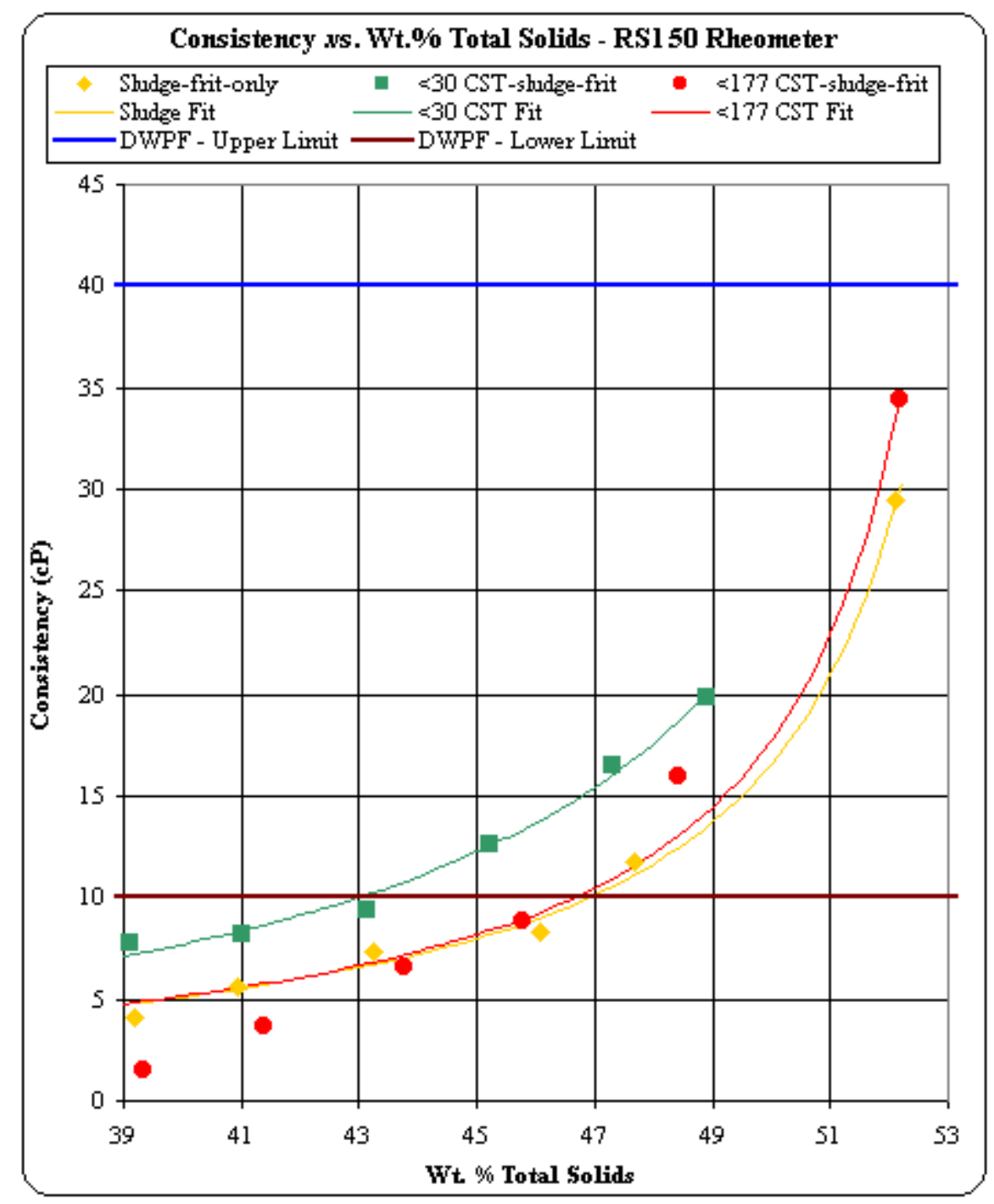


FIGURE 18. Consistency versus Wt. \% IS - RV20

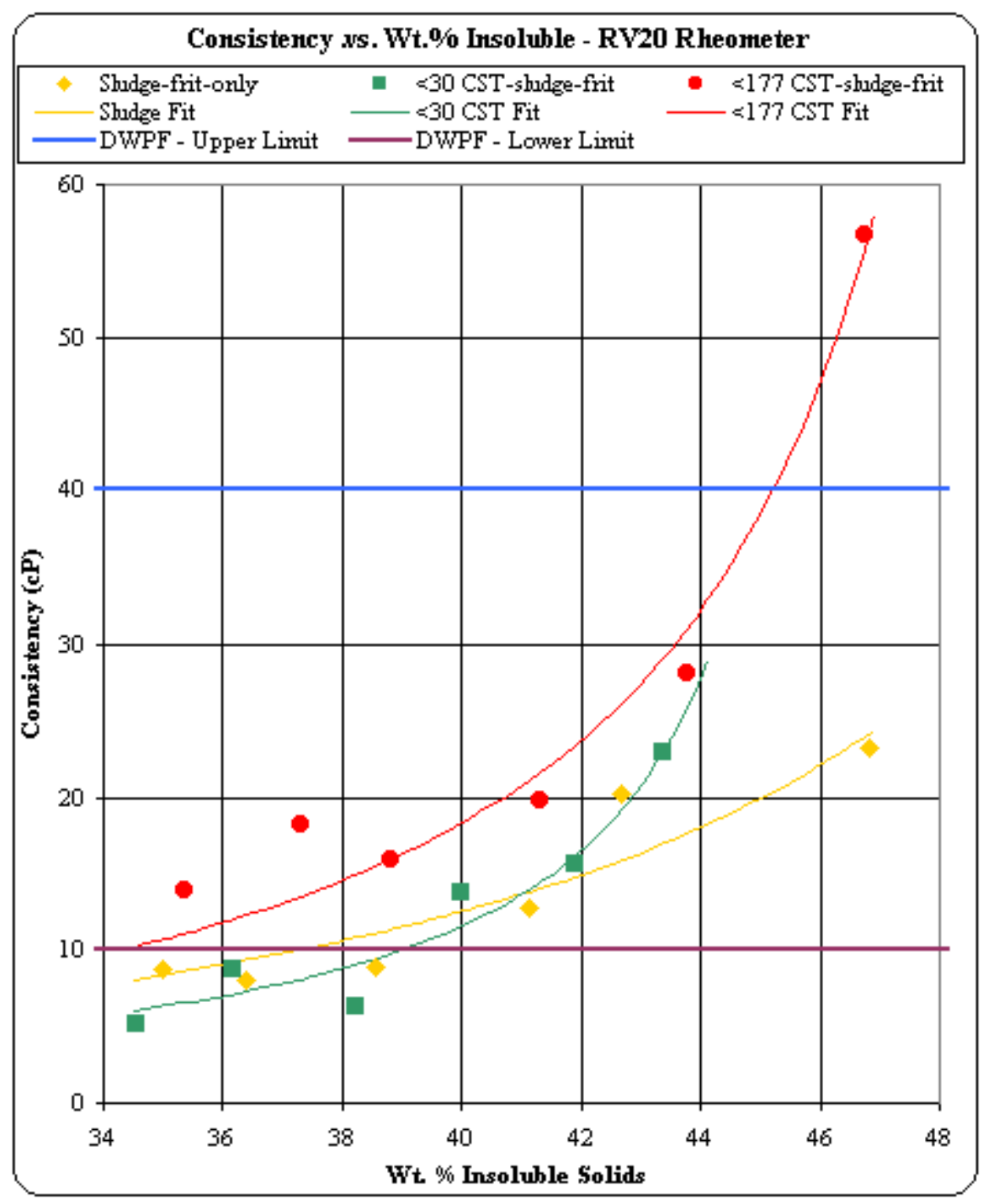

FIGURE 19. Consistency versus Wt. \% IS - RS150

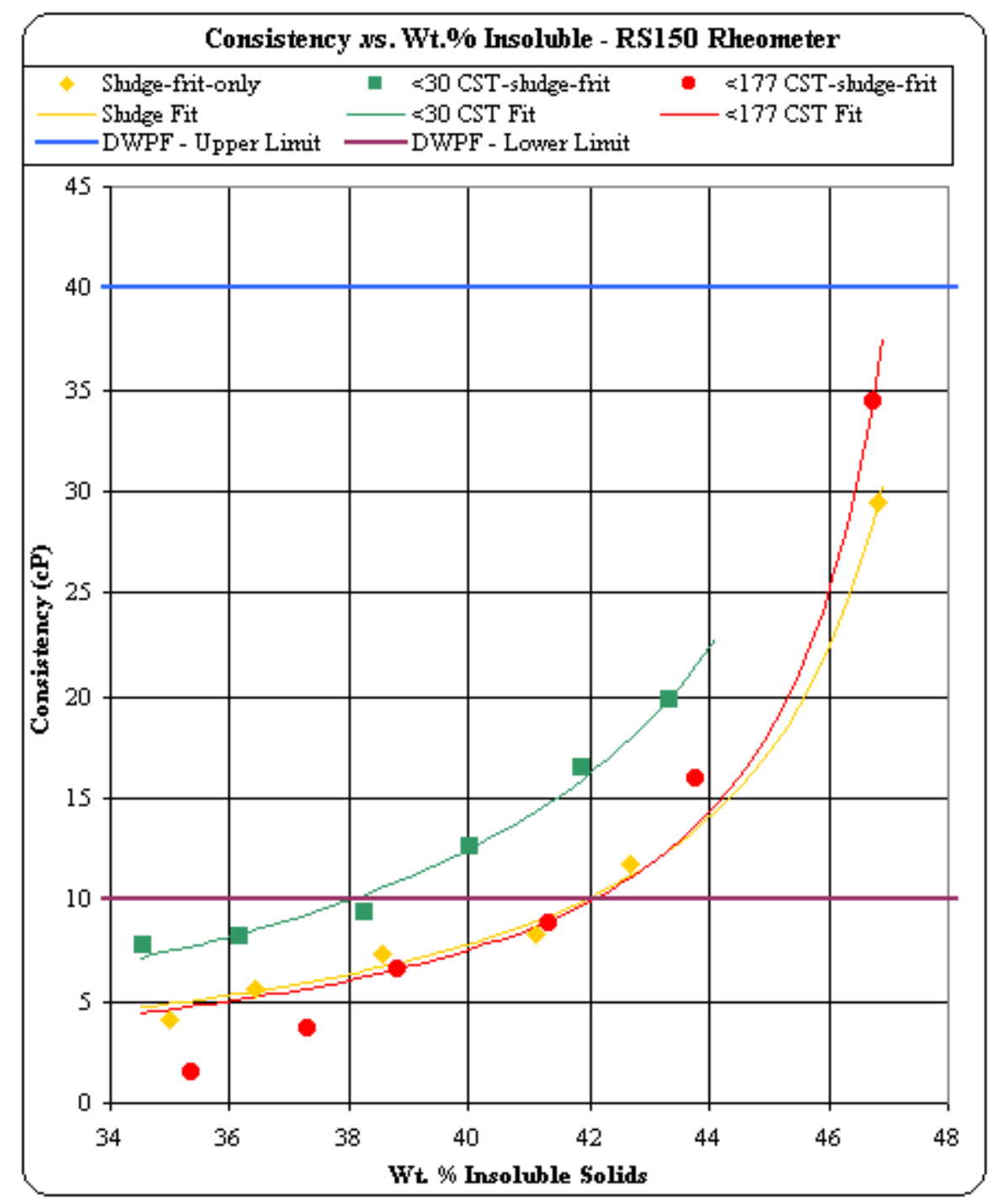


WSRC-TR-2001-00069

Page 30 of 35

The curve fitted data in Table 14 can be used together to describe the flow curves for any weight percent solids the curves were fitted. The yield stress equation [3] and consistency equation [4] were substituted into the Bingham Plastic equation [2], yielding a relationship between the flow model and fitted parameters.

$$
\tau=\tau_{o}+\eta \dot{\gamma}=\frac{\exp ^{b 1 * C}}{\left(1-C / C_{\max , 1}\right)}+\frac{\exp ^{b 2 * C}}{\left(1-C / C_{\max , 2}\right)} \dot{\gamma}\left(\mathrm{dynes} / \mathrm{cm}^{2}\right)
$$

Flow curves were generated between 0 to $350 \mathrm{sec}^{-1}$ using the data in Table 14 for all the melter feeds and the results are shown in Figure 20 (the Haake software uses the symbol $\mu$ for $\eta$ ). A lower TS of $39.4 \mathrm{wt}$. \% and a upper TS of $48.9 \mathrm{wt} . \%$ were used, since this would cover the range in which all the data in Table 14 had been fitted to. The minimum and maximum DWPF design limits are also shown in Figure 20, which provides an area for operation. The flow curves were colored, such that each condition, wt. \% TS and type of instrument used, could be compared. The results indicate at low TS, that all three melter feed behave about the same and were all within the DWPF design limit box using either instrument. The $<177 \mu \mathrm{m}$ CST-sludge-frit, RS150 data does have a higher yield stress, which initially exceeded the DWPF upper design limits, but after $100 \mathrm{sec}^{-1}$ came within the DWPF design limit. As the concentration increased to 48.9 wt. \% TS, all the flow curves exceeded the DWPF design limit. The Sludge-frit-only was the least viscous, followed by the $<30 \mu \mathrm{m}$ CST-sludge-frit and then by the $<177 \mu \mathrm{m}$ CSTsludge-frit. This pattern was consistent with both the RV20 and RS150 data. The average difference in the shear stress at $350 \mathrm{sec}^{-1}$ was $40 \%$ greater for $<177 \mu \mathrm{m}$ CST-sludge-frit and $30 \%$ greater for $<30 \mu \mathrm{m}$ CST-sludge-frit when compared to the Sludge-frit-only, for both the RV20 and RS150 data.

Hydraulic calculations, using the density in Table 11, correlated data in Table 14 and equation [6] was not performed but is recommended. The hydraulic losses would closely follow that of the flow curves shown in Figure 20, but would take into consideration the density and piping configuration. The hydraulic losses can be determined using the method outlined by Darby ${ }^{14}$ for straight pipe, assuming the fluid can be treated as a Bingham Plastic. Entrance/exit and fitting losses can be estimated using reference 15. The flow curves can then be plotted against the pump curve to determine if there are operational issues. As for mixing, this issue could be addressed using computational fluid dynamics, where the yield stress would most likely be the limiting factor. 
WSRC-TR-2001-00069

Page 31 of 35

FIGURE 20. Flow Curves Using Equation [6] and wt. \% TS

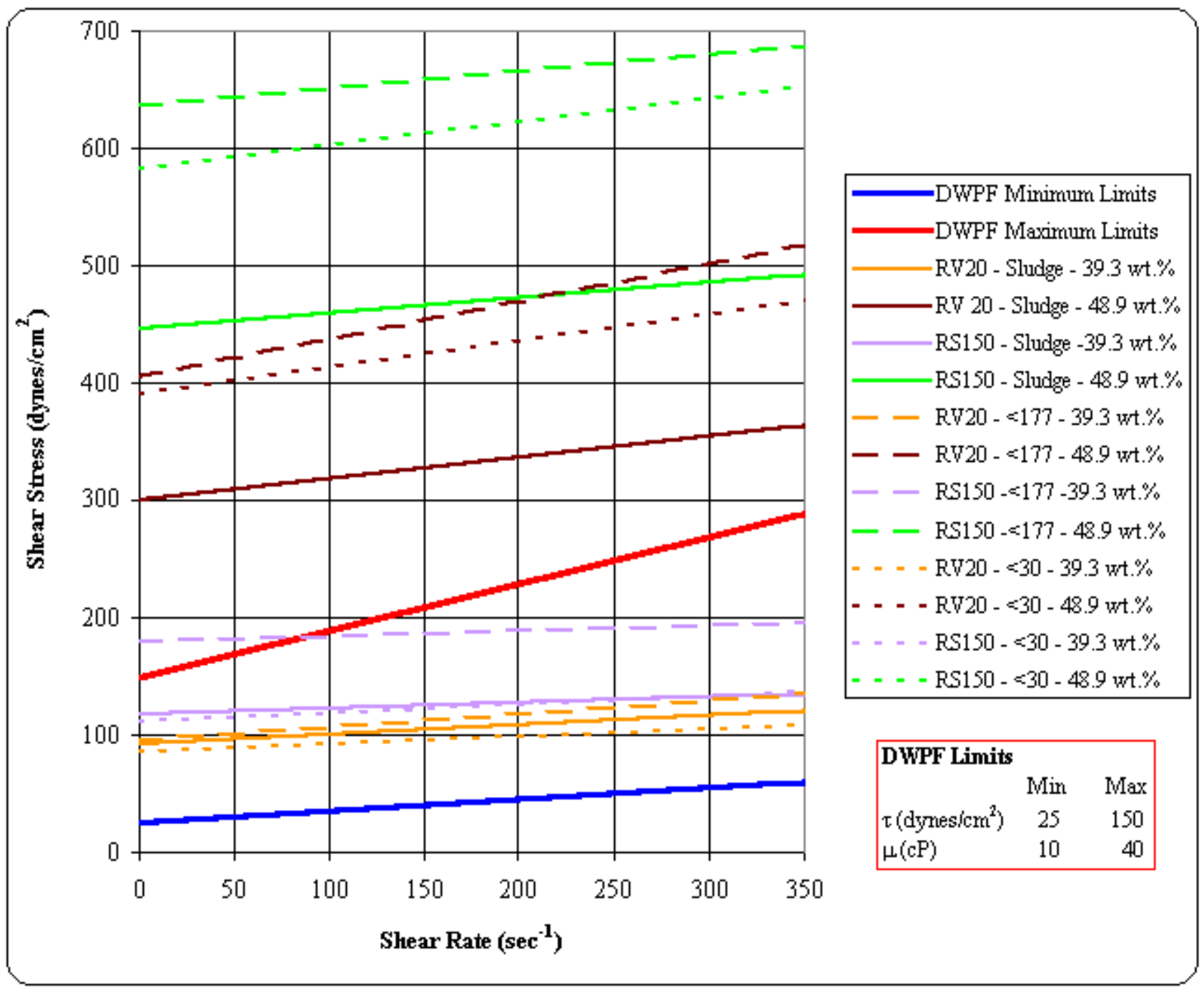

\section{CONCLUSIONS}

In general, at low wt. $\%$ solids, the behavior of the Sludge-frit-only, $<177 \mu \mathrm{m}$ CST-sludge-frit and $<30 \mu \mathrm{m}$ CST-sludge-frit slurries were similar rheologically. As the wt. \% solids increased, the $<177 \mu \mathrm{m}$ CST-sludge-frit was the most viscous, followed by the $<30 \mu \mathrm{m}$ CST-sludge-frit, and then the Sludge-frit-only slurry. The change was most notable in the yield stress.

The yield stresses of CST-sludge-frit melter feeds equaled the yield stresses of sludge-frit-only melter feeds that contained higher weight $\%$ total solids. The difference in weight percent total solids between the CST-sludge-frit and sludge-frit-only melter feeds was anywhere from 0 to 4 wt. \% total solids, depending on the selected yield stress. This means that the presence of CST in the DWPF melter feed would potentially lead to a reduction in melt rate due to the additional water in the CST-sludge-frit melter feeds. 
WSRC-TR-2001-00069

Page 32 of 35

Summarizing other behaviors:

- When the yield stress was less than 150 dynes $/ \mathrm{cm}^{2}$, the consistency was often less than 10 cP; hence the data was almost never within DWPF design basis region for all the slurries.

- The yield stress data seems to show the same general behavior when comparing the blends using either the RV20 or RS150 data.

- The yield stress data using either the RV20 and RS150 gave approximately the same wt. \% TS and wt. \% IS at which the <30 $\mu \mathrm{m}$ CST-sludge-frit crossed the Sludge-frit-only.

- The consistency data varied greatly for the RV20 data. This was most likely due to the curvature in the raw data and the selection of the range in which the data was analyzed

- The results from the RS150 data seemed to produce a smoother function for the yield stress and consistency with respect to wt. \% solids as compared to the RV20 data.

- The $<30 \mu \mathrm{m}$ CST-sludge-frit yield stress was comparable to the Blend-sludge-frit yield stress where the DWPF design limit was not exceeded.

- The DWPF yield stress upper design limit was exceeded at a very low wt. \% TS and IS values for all the Blends. These compare well with the same Tank $8 / 40$ Blends studied in Reference 13.

- The $<30 \mu \mathrm{m}$ CST-sludge-frit flow curves obtained using the RS150 shows a slurry that has a structure that recovers when the shear rate is reduced unlike the $<177 \mu \mathrm{m}$ CST-sludge-frit and the Sludge-frit-only slurries.

- The $<30 \mu \mathrm{m}$ CST-sludge-frit yield stress increases more rapidly than the $<177 \mu \mathrm{m}$ CSTsludge-frit yield stress as the wt. \% IS or TS increases.

- In general, the rheological behavior of the Tank 8/40 Blends containing CST is more viscous than that of the Tank $8 / 40$ Blend. After 43 wt. \% TS or 39 wt. \% IS solids, the yield stress for the CST slurries starts to diverge and rapidly increases from that of Tank 8/40 Blend as the wt.\% solids increases.

\section{FUTURE WORK}

The experiments were conducted with a base material that was outside of the DWPF design basis for yield stress (25-150 dynes/ $\left.\mathrm{cm}^{2}\right)$ starting at a low wt. \% solids. It needs to be determined if DWPF actually processes within this range. A rheometer with comparable measuring capabilities to the one at TNX is located in the Shielded Cells. A sample of real DWPF melter feed should be submitted for rheological characterization. Additional tests such as varying the $\mathrm{pH}$ could produce a slurry that can be processed using the existing DWPF slurry design basis limit. 
WSRC-TR-2001-00069

Page 33 of 35

\section{REFERENCES}

1. R. E. Eibling and D. C. Koopman, "CST Melter Feed Characteristization in Support of the 1999 and 2000 Thermal Fluids Lab Hydragard Testing (U)", WSRC-TR-2000-00445, Revision 0, March 1, 2001.

2. D. C. Koopman, "Sludge Batch 2 (Macrobatch 3) Flowsheet Studies With Simulants (U)", WSRC-TR-2000-00398, Rev. 0, October 9, 2000

3. D. C. Koopman and D. P. Lambert, "Hydrogen Generation and Foaming During Tests in The GFPS Simulating DWPF Operations with Tank 42 Sludge and CST (U)", WSRC-TR-9900302, September 3, 1999.

4. D. C. Koopman, "Nominal Tank 8/40 Blend Run With No CST (U)", SRT-PTD-200000085, Rev. 0, November 8, 2000.

5. D. C. Koopman, “Tank $8 / 40$ Blend Run With $<177 \mu$ CST (U)", SRT-PTD-2000-00087, Rev. 0 , November 8, 2000.

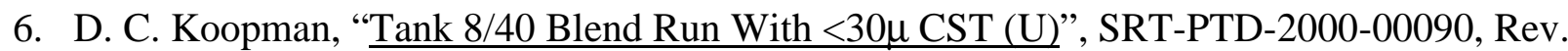
0 , November 16, 2000.

7. J. R. Hester, "High Level Waste Characterization System", WSRC-TR-96-0264, December, 1996.

8. W. E. Daniel, "Conduct of R\&D for Hydrogen Study for Tank 42 Sludge and Loaded CST DWPF Bench Scale Runs (U)”, SRT-PTD-99-0024, May 21, 1998.

9. Laboratory Notebook, “CST SRAT/SME Rheology”, WSRC-NB-99-00169.

10. J. C. Marek, "Correction Factor For Soluble and Insoluble Solids (U)", SRTC-PTD-92-0040, Rev. 0, August 29, 1992.

11. J.C. Marek, "Rheology Measurements of Simulated Slurry Mix Evaporator Material (U)", WSRC-TR-97-00343, Rev. 0, October 17, 1997.

12. C.A. Shook and M.C. Roco, "Slurry Flow - Principles and Practice", ButterworthHeinemann, 1991, pages $61-64$.

13. D. C. Koopman, "Sludge Batch 2 (Macrobatch 3) Rheology Studies with Simulant (U)", WSRC-TR-2001-00051, February 23, 2001.

14. R. Darby, R. Mun and D. V. Boger, "Predict Friction Loss In Slurry Pipe Lines", Chemical Engineering, September 1992. 
WSRC-TR-2001-00069

Page 34 of 35

15. R. Darby, "Chemical Engineering Fluid Mechanics”, Dekker, 1996, Chpt. 7.

16. Laboratory Notebook, “General DWPF Support Activities”, WSRC-NB-2000-00141.

17. DPSTD-80-38, Rev. 2, Technical Data Summary for the Defense Waste Processing Facility Sludge Plant, Part 10, Item 230, September, 1982. 
WSRC-TR-2001-00069

Page 35 of 35

\section{ACKNOWLEDGEMENTS}

The authors wish to acknowledge the following individuals who contributed to the program:

Tony Burckhalter, Jon DuVall, Sammie King, Mary Moss and Vickie Williams who prepared the simulants and carried-out the experiments. These experiments could not have been successfully completed without the unending support of Frances Williams who supports our work in so many ways. 
Table of Figures

FIGURE A - 1: RS150 $\left(0-400 \mathrm{sec}^{-1}\right)$ Sludge-Frit-Only Rheograms...............................................2

FIGURE A - 2: RS150 $\left(0-400 \mathrm{sec}^{-1}\right)<177 \mu \mathrm{m}$ CST-Sludge-Frit Rheograms...................................

FIGURE A - 3: RS150 $\left(0-400 \mathrm{sec}^{-1}\right)<30 \mu \mathrm{m}$ CST-Sludge-Frit Rheograms...................................

FIGURE A - 4: RS150 Sludge-Frit-Only 39.2wt. \%TS ..........................................................

FIGURE A - 5: RS150 Sludge-Frit-Only 40.9wt. \%TS ...........................................................

FIGURE A - 6: RS150 Sludge-Frit-Only 43.3wt. \%TS ............................................................

FIGURE A - 7: RS150 Sludge-Frit-Only 46.1wt. \%TS ............................................................

FIGURE A - 8: RS150 Sludge-Frit-Only 47.7 wt. \%TS ........................................................

FIGURE A - 9: RS150 Sludge-Frit-Only $52.1 \mathrm{wt}$ \%TS ........................................................

FIGURE A - 10: RS150 < $177 \mu$ m CST Sludge-Frit 39.3 wt. \%TS ...............................................

FIGURE A - 11: RS150 < $177 \mu \mathrm{m}$ CST Sludge-Frit 41.4 wt. \%TS ...............................................

FIGURE A - 12: RS150 < $177 \mu \mathrm{m}$ CST Sludge-Frit 43.8 wt. \%TS ...............................................

FIGURE A - 13: RS150 < $177 \mu \mathrm{m}$ CST Sludge-Frit 45.8 wt. \%TS …………………………......

FIGURE A - 14: RS150 < $177 \mu \mathrm{m}$ CST Sludge-Frit 48.4 wt. \%TS ………………………….....10

FIGURE A - 15: RS150 < $177 \mu \mathrm{m}$ CST Sludge-Frit 52.2 wt. \%TS ............................................10

FIGURE A - 16: RS150 < $30 \mu \mathrm{m}$ CST Sludge-Frit 39.1 wt. \%TS .................................................11

FIGURE A - 17: RS150 < $30 \mu \mathrm{m}$ CST Sludge-Frit $41.0 \mathrm{wt} . \%$ TS ................................................11

FIGURE A - 18: RS150 < $30 \mu \mathrm{m}$ CST Sludge-Frit 43.2 wt. \%TS .............................................12

FIGURE A - 19: RS150 < $30 \mu \mathrm{m}$ CST Sludge-Frit 45.2 wt. \%TS ...............................................12

FIGURE A - 20: RS150 < $30 \mu \mathrm{m}$ CST Sludge-Frit 47.3 wt. \%TS …………………………........13

FIGURE A - 21: RS150 < $30 \mu \mathrm{m}$ CST Sludge-Frit 48.9 wt. \%TS .............................................13

FIGURE A - 22: RV20 Sludge-Frit-Only 39.2 wt. \%TS ……………………..........................14

FIGURE A - 23: RV20 Sludge-Frit-Only 40.9 wt. \% TS .......................................................14

FIGURE A - 24: RV20 Sludge-Frit-Only 43.3 wt. \% TS .......................................................14

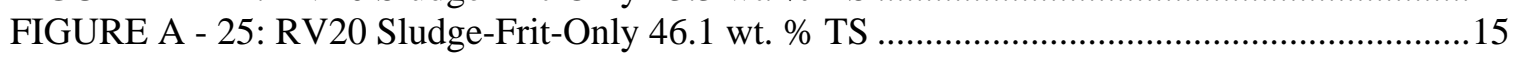

FIGURE A - 26: RV20 Sludge-Frit-Only $47.7 \mathrm{wt}$ \% TS .......................................................15

FIGURE A - 27: RV20 Sludge-Frit-Only 52.1 wt. \% TS .........................................................15

FIGURE A - 28: RV20 < $177 \mu$ m CST-Sludge-Frit 39.3 wt. \% TS ............................................16

FIGURE A - 29: RV20 < $177 \mu$ m CST-Sludge-Frit 41.4 wt. \% TS ................................................16

FIGURE A - 30: RV20 < $177 \mu$ m CST-Sludge-Frit 43.8 wt. \% TS ..............................................16

FIGURE A - 31: RV20 < $177 \mu$ m CST-Sludge-Frit $45.8 \mathrm{wt}$ \% TS ..............................................17

FIGURE A - 32: RV20 < $177 \mu$ m CST-Sludge-Frit 48.4 wt. \% TS ...............................................17

FIGURE A - 33: RV20 < $177 \mu$ m CST-Sludge-Frit 52.2 wt. \% TS ............................................17

FIGURE A - 34: RV20 < $30 \mu \mathrm{m}$ CST-Sludge-Frit $39.1 \mathrm{wt}$ \% TS ..............................................18

FIGURE A - 35: RV20 < $30 \mu \mathrm{m}$ CST-Sludge-Frit $41.0 \mathrm{wt}$ \% TS ……………………………....18

FIGURE A - 36: RV20 < $30 \mu \mathrm{m}$ CST-Sludge-Frit $43.2 \mathrm{wt}$ \% TS ............................................18

FIGURE A - 37: RV20 < $30 \mu \mathrm{m}$ CST-Sludge-Frit $45.2 \mathrm{wt}$ \% TS ................................................19

FIGURE A - 38: RV20 < $30 \mu \mathrm{m}$ CST-Sludge-Frit $47.3 \mathrm{wt}$ \% TS ...............................................19

FIGURE A - 39: RV20 < $30 \mu \mathrm{m}$ CST-Sludge-Frit 48.9 wt. \% TS .............................................19

FIGURE A - 40: Particle Size Distribution Sludge-Frit-Only \#1 ................................................20

FIGURE A - 41: Particle Size Distribution Sludge-Frit-Only \#2..................................................20

FIGURE A - 42: Particle Size Distribution < 177 4m CST-Sludge-Frit \#1 .....................................21

FIGURE A - 43: Particle Size Distribution < $177 \mu$ m CST-Sludge-Frit \#2.....................................21

FIGURE A - 44: Particle Size Distribution < $30 \mu \mathrm{m}$ CST-Sludge-Frit \#1......................................22

FIGURE A - 45: Particle Size Distribution < $30 \mu \mathrm{m}$ CST-Sludge-Frit \#2.....................................22

Table of Tables

TABLE A - 1: Analytical Results - ICP-ES . 
FIGURE A - 1: RS150 (0-400 $\left.\mathrm{sec}^{-1}\right)$ Sludge-Frit-Only Rheograms

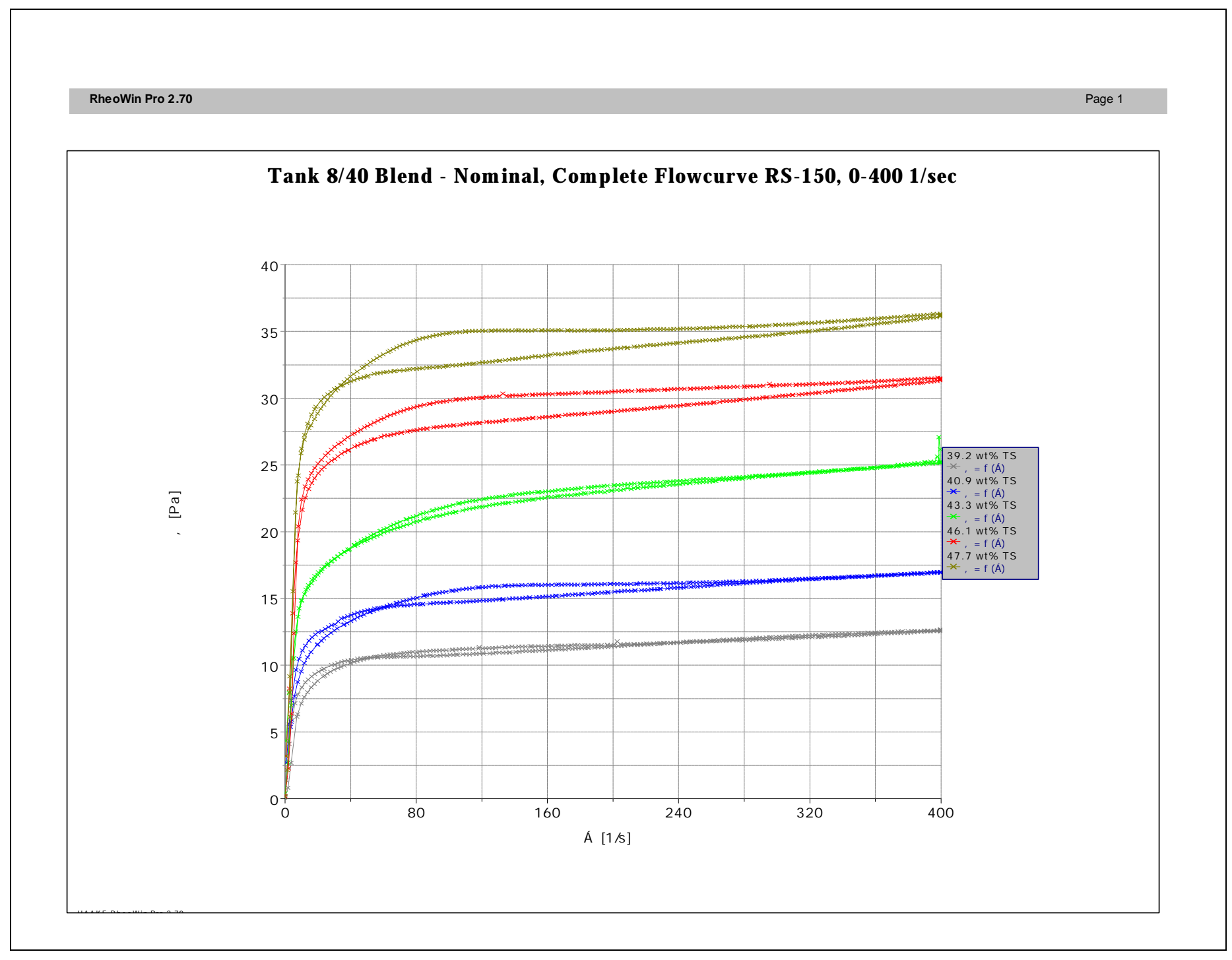


FIGURE A - 2: RS150 $\left(0-400 \mathrm{sec}^{-1}\right)<177 \mu \mathrm{m}$ CST-Sludge-Frit Rheograms

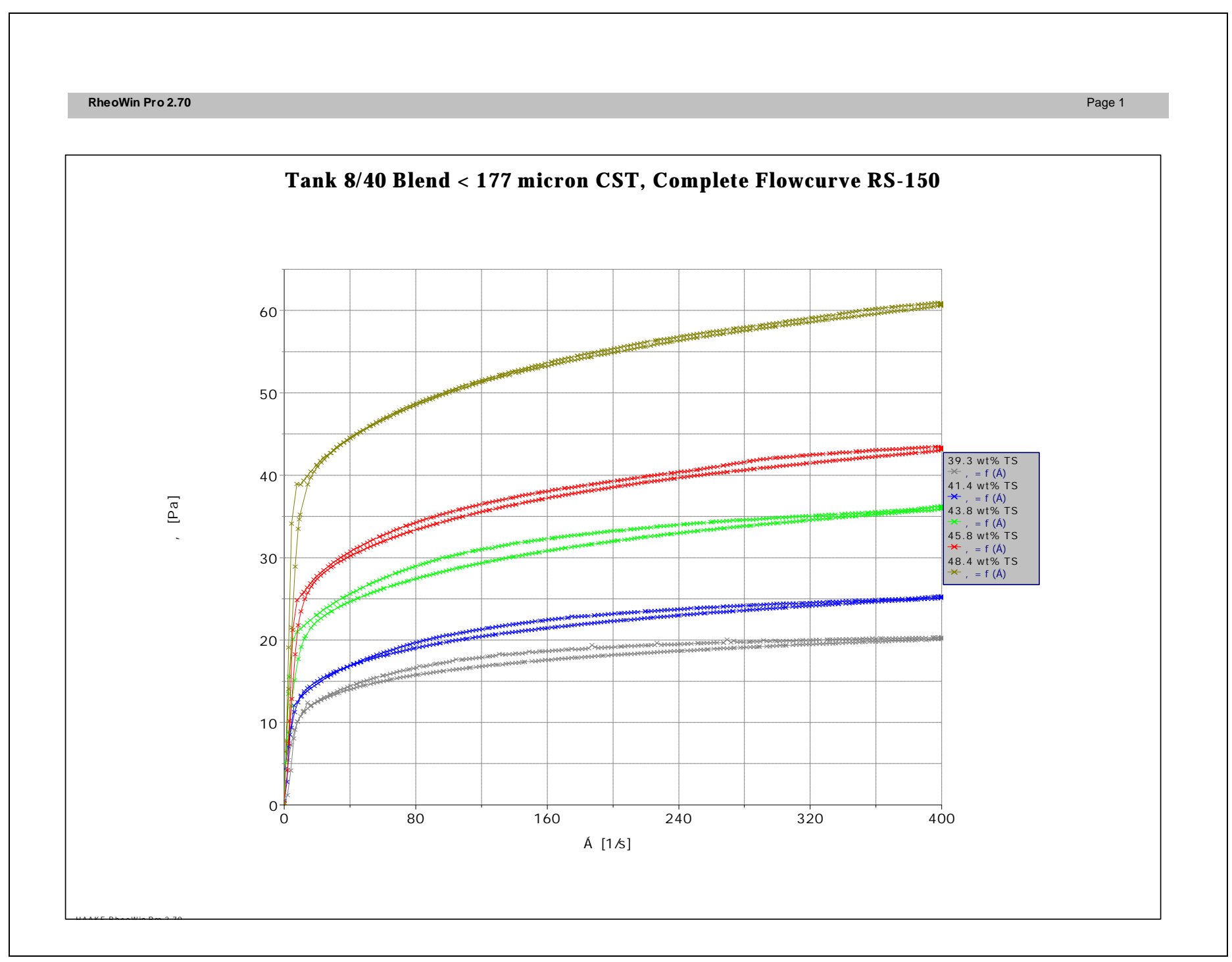


FIGURE A - 3: RS150 $\left(0-400 \sec ^{-1}\right)<30 \mu \mathrm{m}$ CST-Sludge-Frit Rheograms

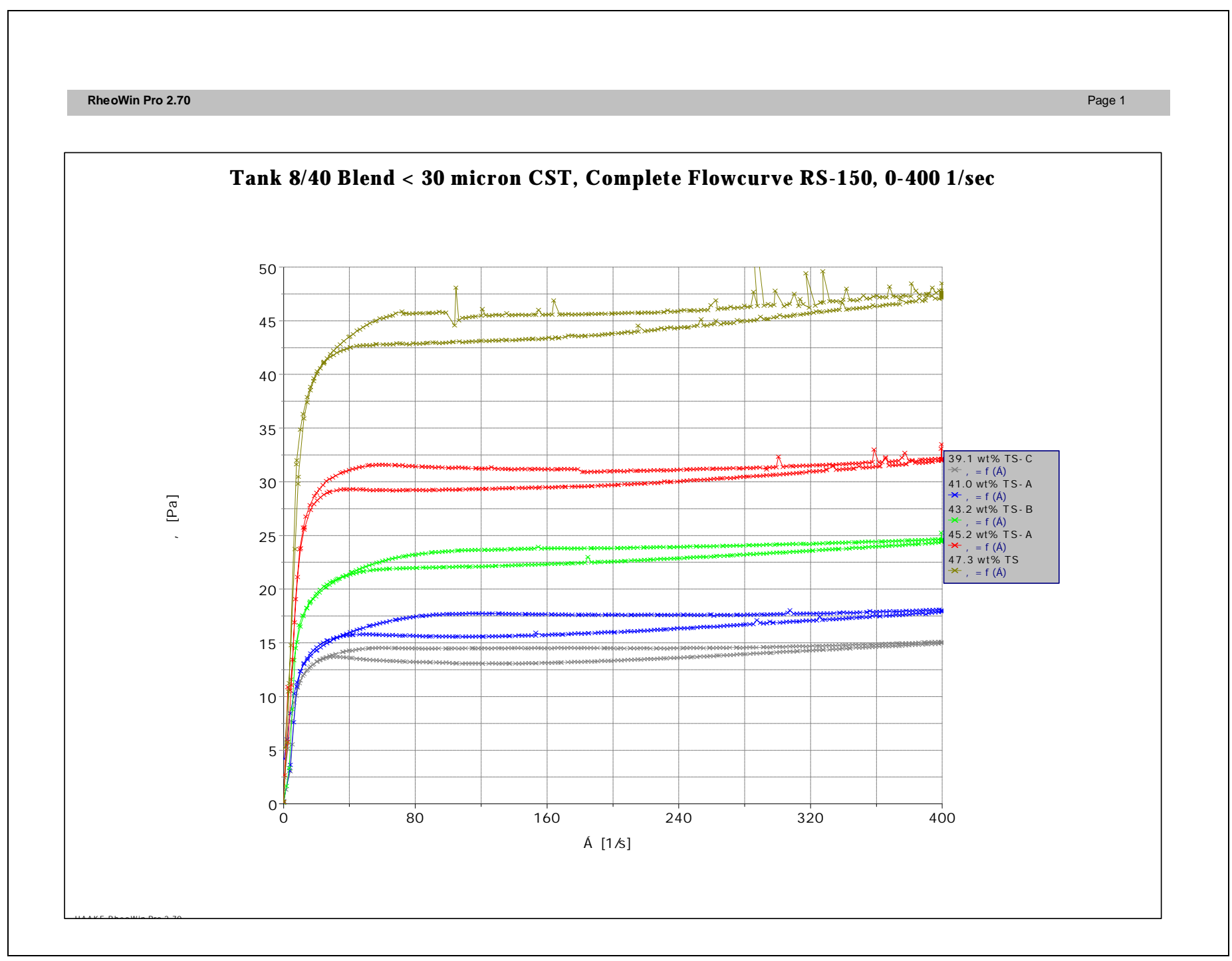




\section{APPENDIX}

WSRC-TR-2001-00069

Page A-5 of A - 23

FIGURE A - 4: RS150 Sludge-Frit-Only 39.2wt. \% TS

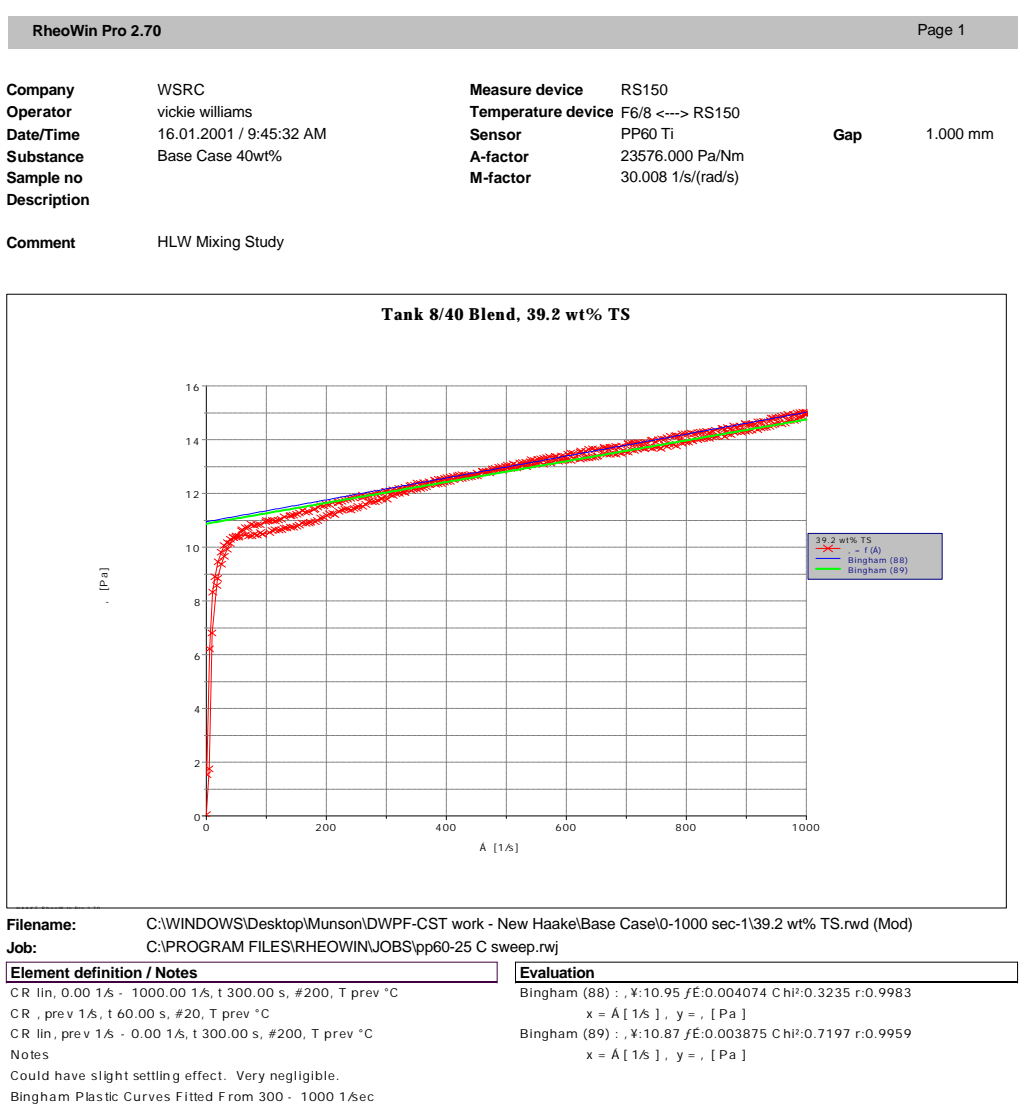

FIGURE A - 5: RS150 Sludge-Frit-Only 40.9wt. \% TS

$\begin{array}{ll}\text { Rheowin Pro } 2.70 & \text { Page } 1\end{array}$

\begin{tabular}{|c|c|c|c|c|}
\hline $\begin{array}{l}\text { Company } \\
\text { Operator } \\
\text { Date/Time } \\
\text { Substance } \\
\text { Sample no } \\
\text { Description }\end{array}$ & $\begin{array}{l}\text { WSRC } \\
\text { vickie williams } \\
\text { 16.01.2001/ 10:03:47 AM } \\
\text { Base Case 42wt\% }\end{array}$ & $\begin{array}{l}\text { Measure device } \\
\text { Temperature device } \\
\text { Sensor } \\
\text { A-factor } \\
\text { M-factor }\end{array}$ & $\begin{array}{l}\text { RS150 } \\
\text { F6/8<---> RS150 } \\
\text { PP60 Ti } \\
23576.000 \mathrm{~Pa} / \mathrm{Nm} \\
29.9961 / \mathrm{s} /(\mathrm{rad} / \mathrm{s})\end{array}$ & Gap \\
\hline
\end{tabular}

Comment HLW Mixing Study

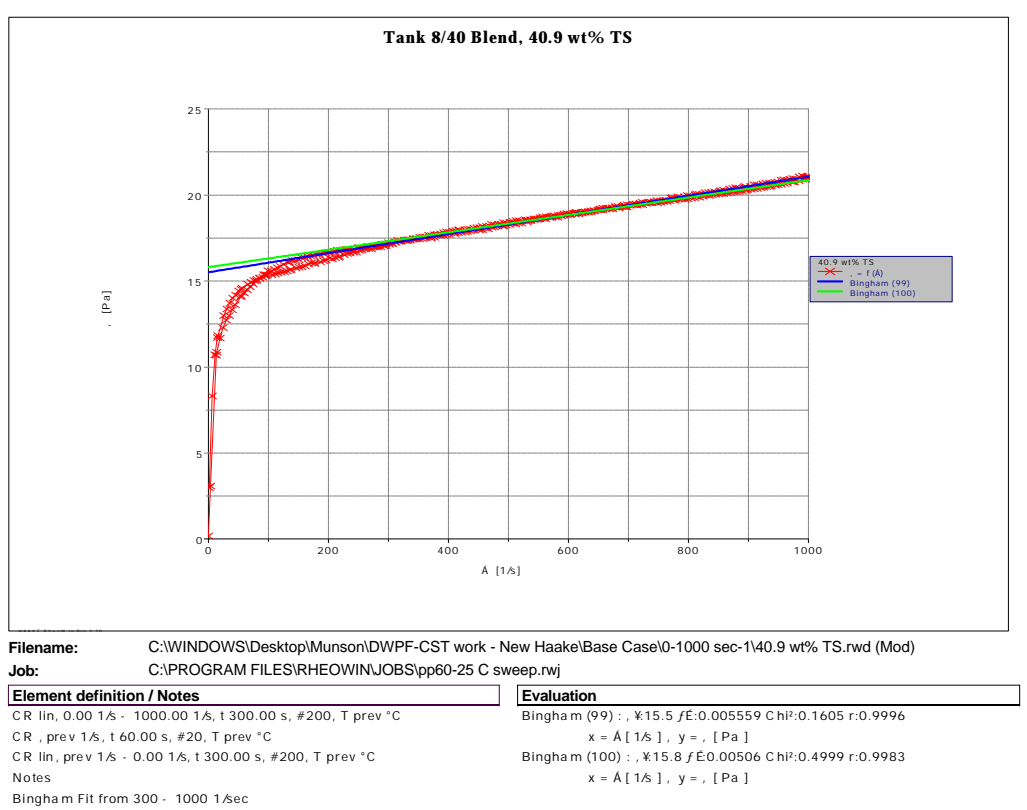




\section{APPENDIX}

WSRC-TR-2001-00069

Page A-6 of A - 23

FIGURE A - 6: RS150 Sludge-Frit-Only 43.3wt. \% TS

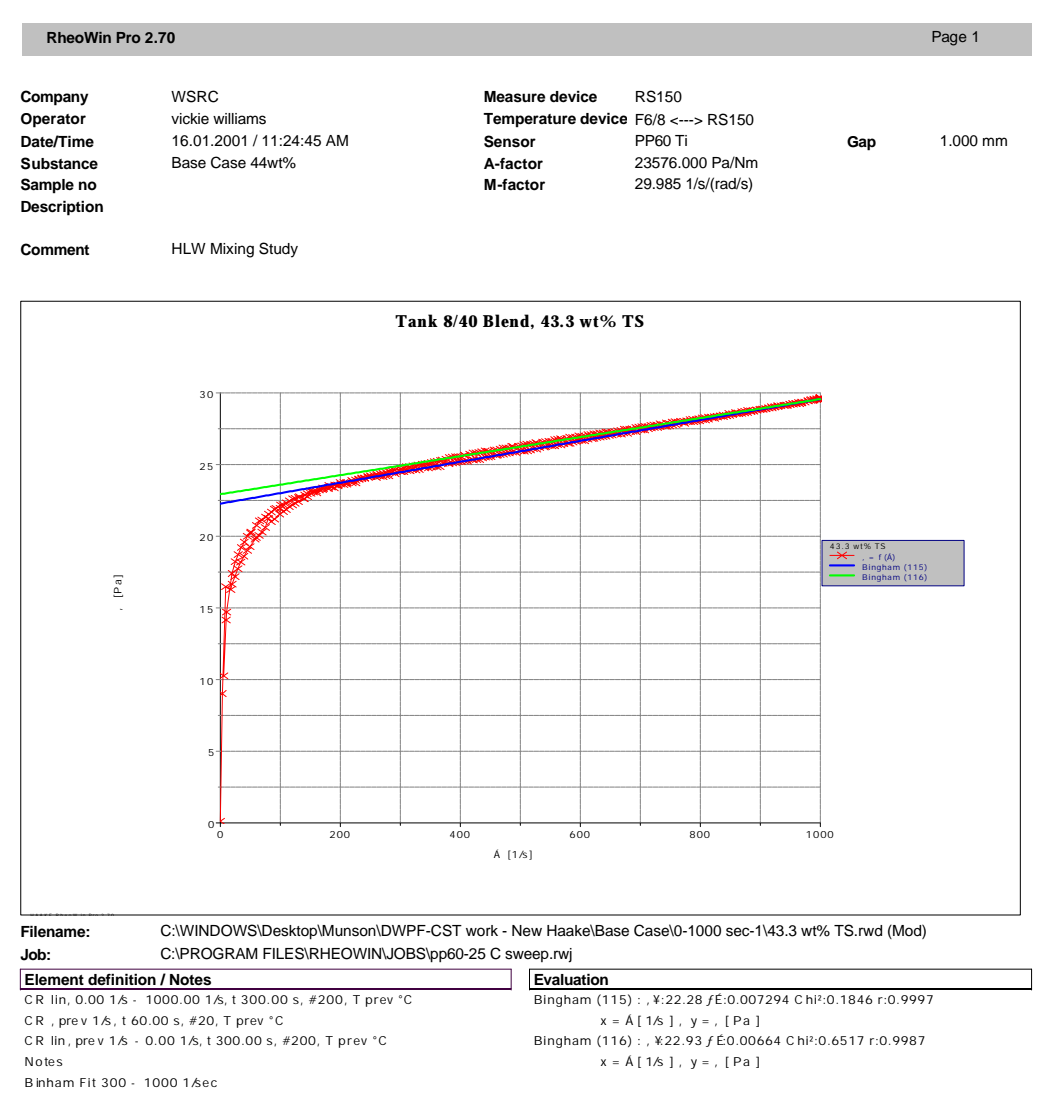

FIGURE A - 7: RS150 Sludge-Frit-Only 46.1wt. \% TS

$\begin{array}{ll}\text { RheoWin Pro } 2.70 & \text { Page } 1\end{array}$

$\begin{array}{ll}\text { Company } & \text { WSRC } \\ \text { Operator } & \text { vickie williams } \\ \text { Dater/Time } & 16.01 .2001 / 11: 43: 09 \text { AM } \\ \text { Substance } & \text { Base Case 46w1\% } \\ \text { Sample no } & \\ \text { Description } & \\ \text { Comment } & \text { HLW Mixing Study }\end{array}$

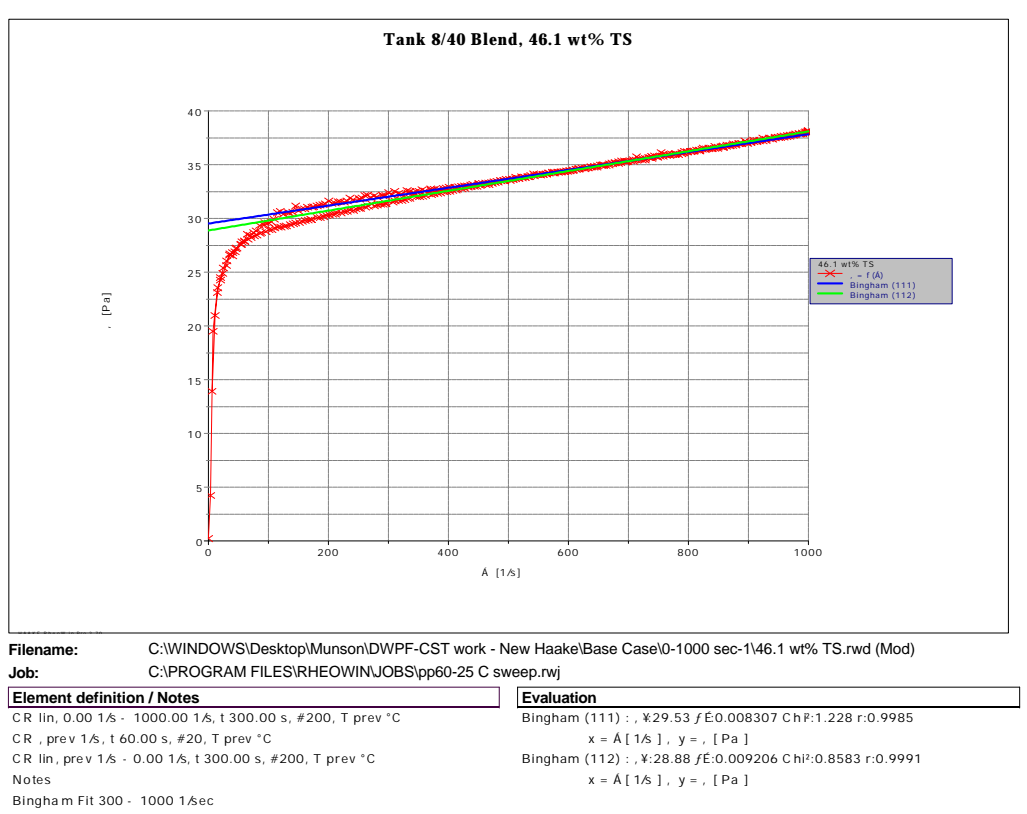




\section{APPENDIX}

WSRC-TR-2001-00069

Page A-7 of A - 23

FIGURE A - 8: RS150 Sludge-Frit-Only 47.7 wt. \% TS

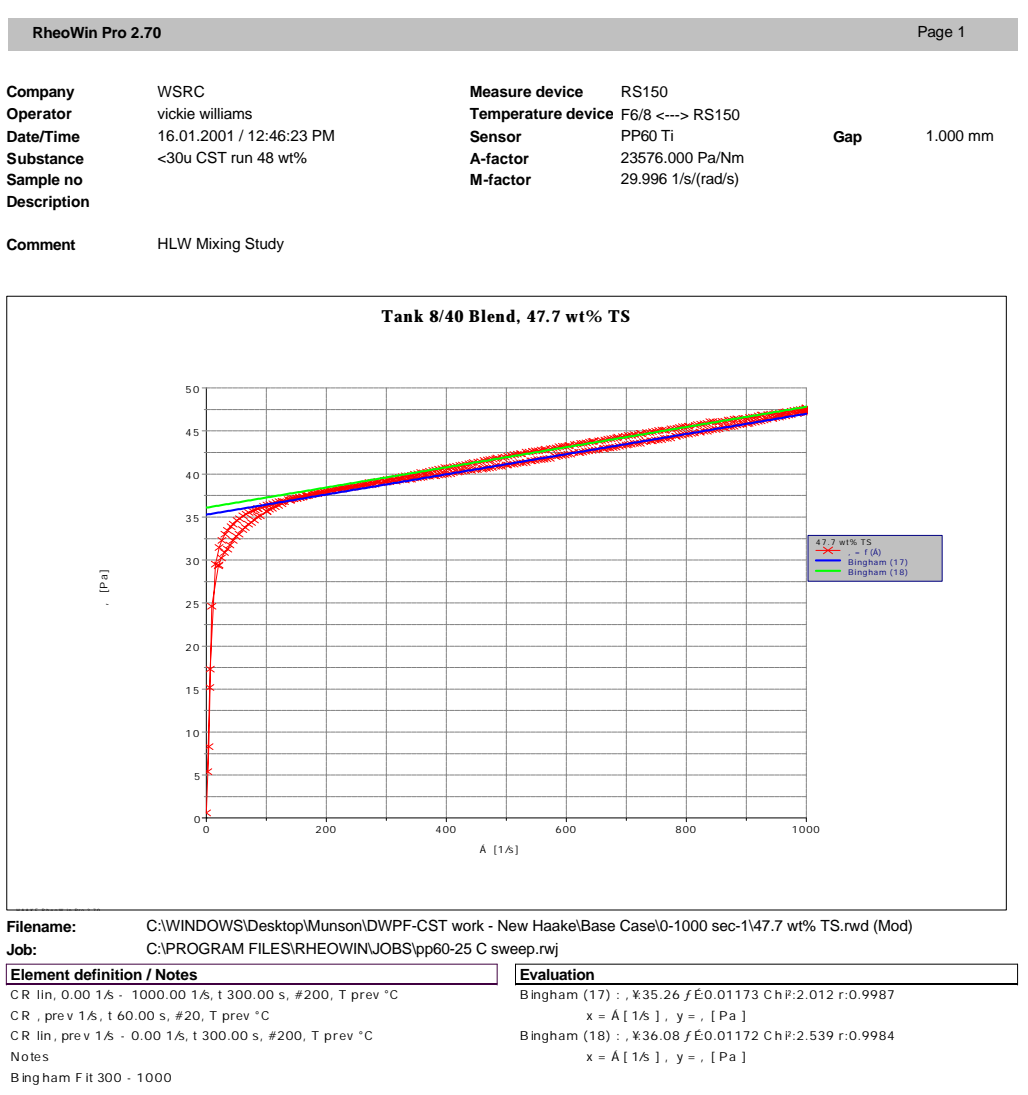

FIGURE A - 9: RS150 Sludge-Frit-Only $52.1 \mathrm{wt}$ \% TS

Rheowin Pro 2.70 Page 1

\begin{tabular}{|c|c|c|c|c|c|}
\hline $\begin{array}{l}\text { Company } \\
\text { Operator } \\
\text { DaterTime } \\
\text { Substance } \\
\text { Sample no } \\
\text { Description }\end{array}$ & $\begin{array}{l}\text { WSRC } \\
\text { vickie williams } \\
1 \text { 1.601.2001/13:04:29 PM } \\
\text { Base Case } 50 \text { wit }\end{array}$ & $\begin{array}{l}\text { Measure device } \\
\text { Temperature device } \\
\text { Sensor } \\
\text { A-factor } \\
\text { M-factor }\end{array}$ & $\begin{array}{l}\text { RS150 } \\
\text { F6/8<-..> RS150 } \\
\text { PP60 Ti } \\
23576.000 \text { Pa/Nm } \\
30.0221 / \mathrm{s} /(\mathrm{rad} / \mathrm{s})\end{array}$ & Gap & $0.999 \mathrm{~mm}$ \\
\hline
\end{tabular}

Comment HLW Mixing Study

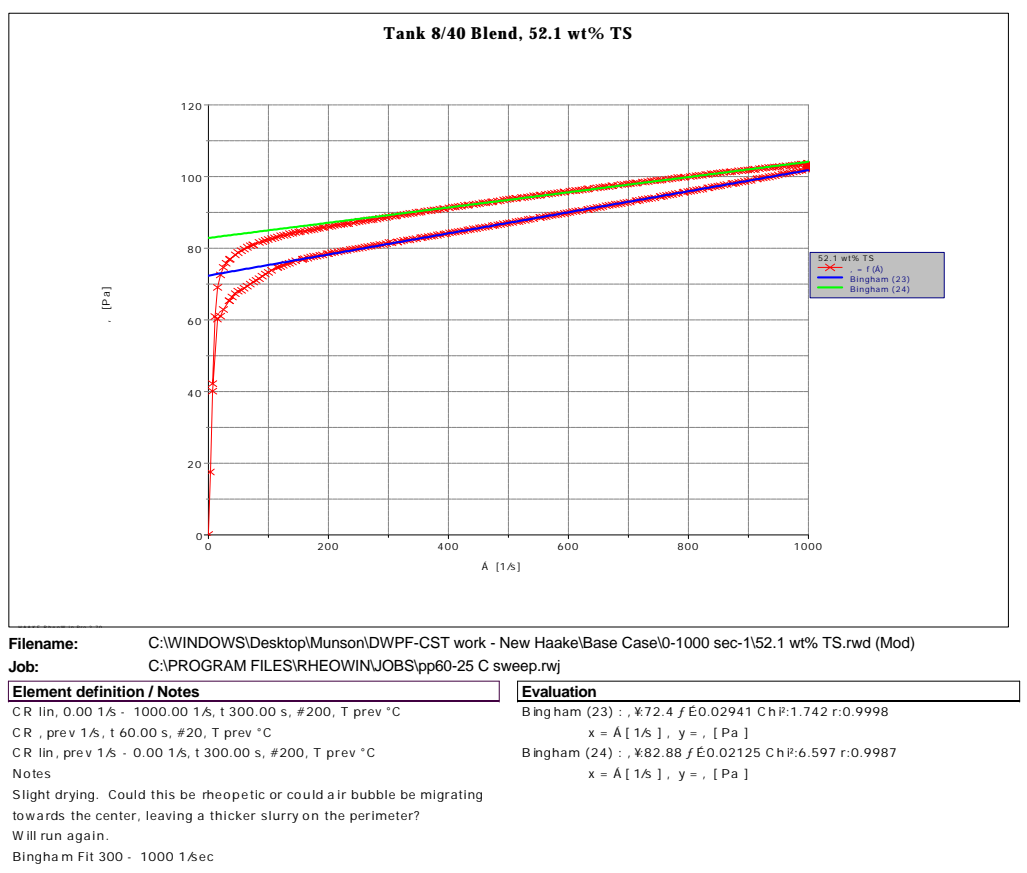




\section{APPENDIX}

WSRC-TR-2001-00069

Page A-8 of A - 23

FIGURE A - 10: RS150 < $177 \mu \mathrm{m}$ CST Sludge-Frit 39.3 wt. \% TS

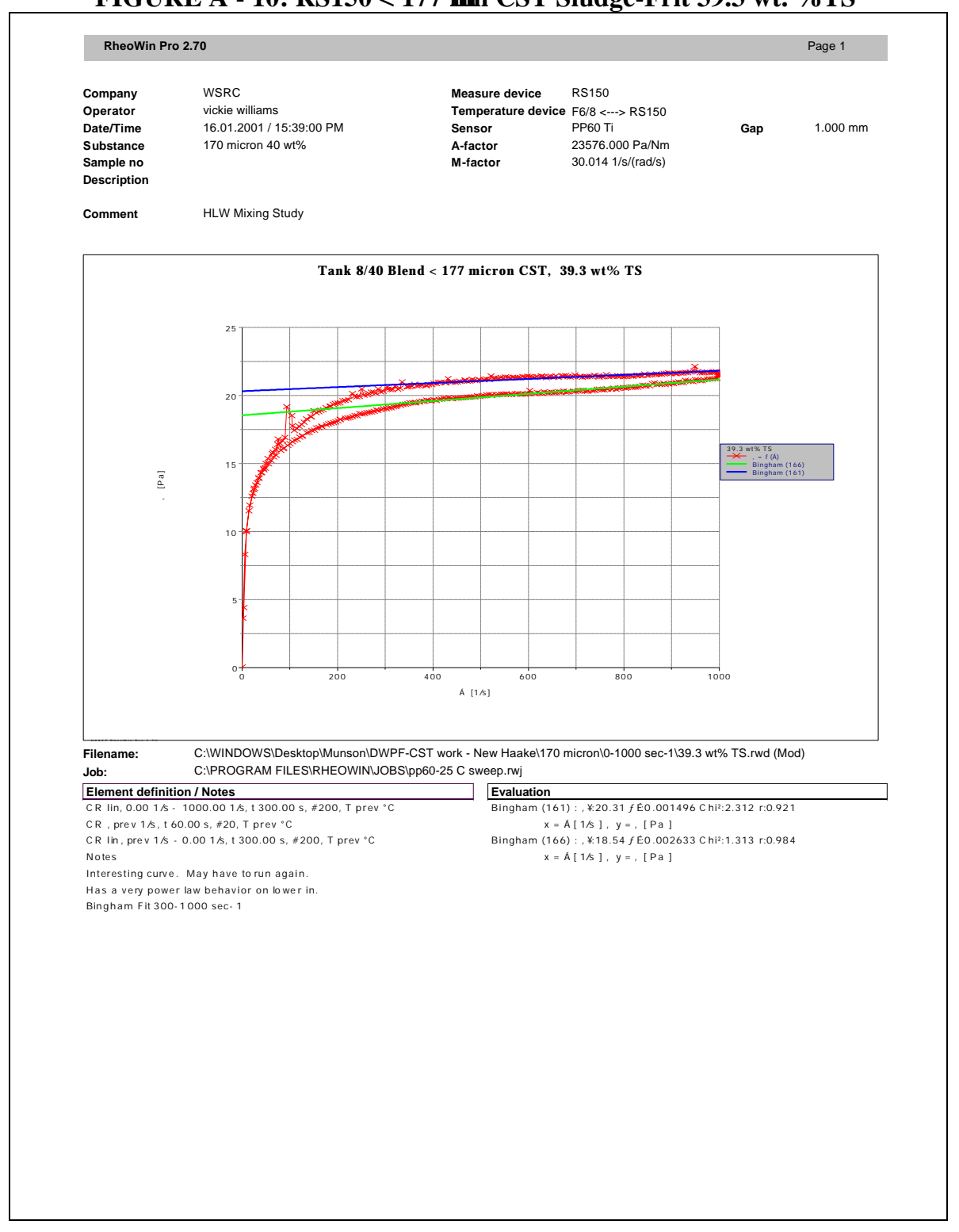

\section{FIGURE A - 11: RS150 < $177 \mu \mathrm{m}$ CST Sludge-Frit 41.4 wt. \% TS}

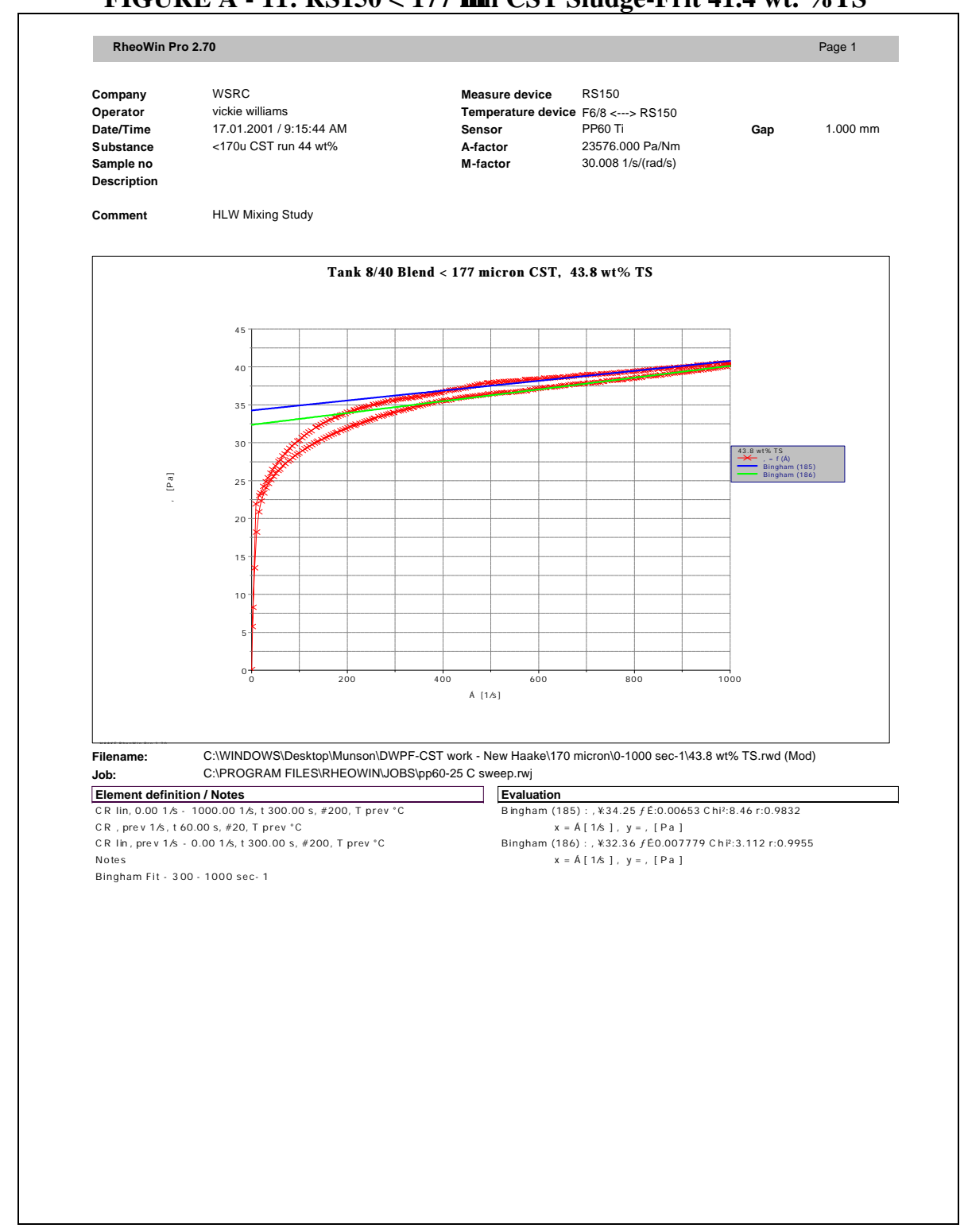




\section{APPENDIX}

WSRC-TR-2001-00069

Page A-9 of A - 23

\section{FIGURE A - 12: RS150 < $177 \mu$ m CST Sludge-Frit 43.8 wt. \% TS}

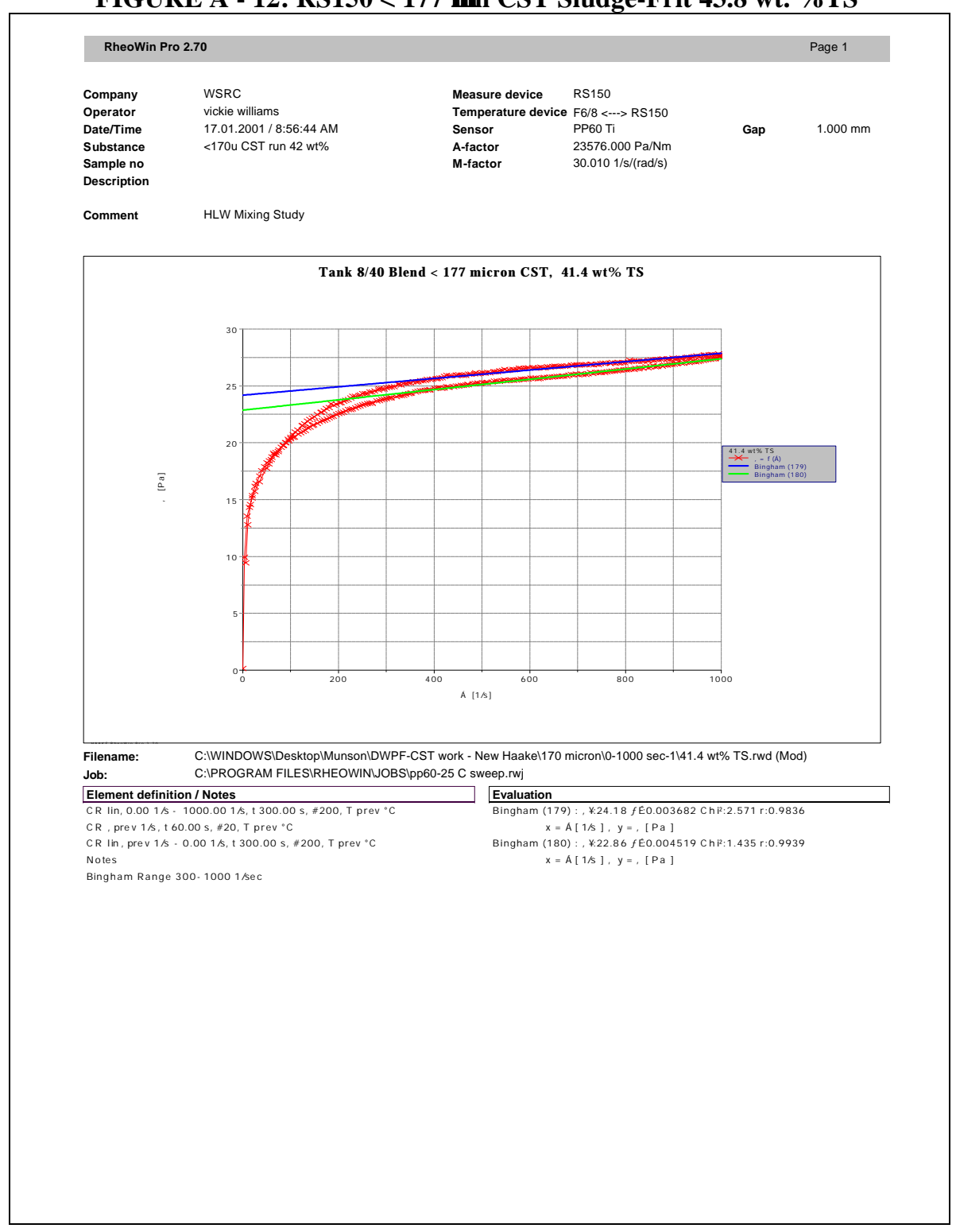

\section{FIGURE A - 13: RS150 < $177 \mu$ m CST Sludge-Frit 45.8 wt. \% TS}

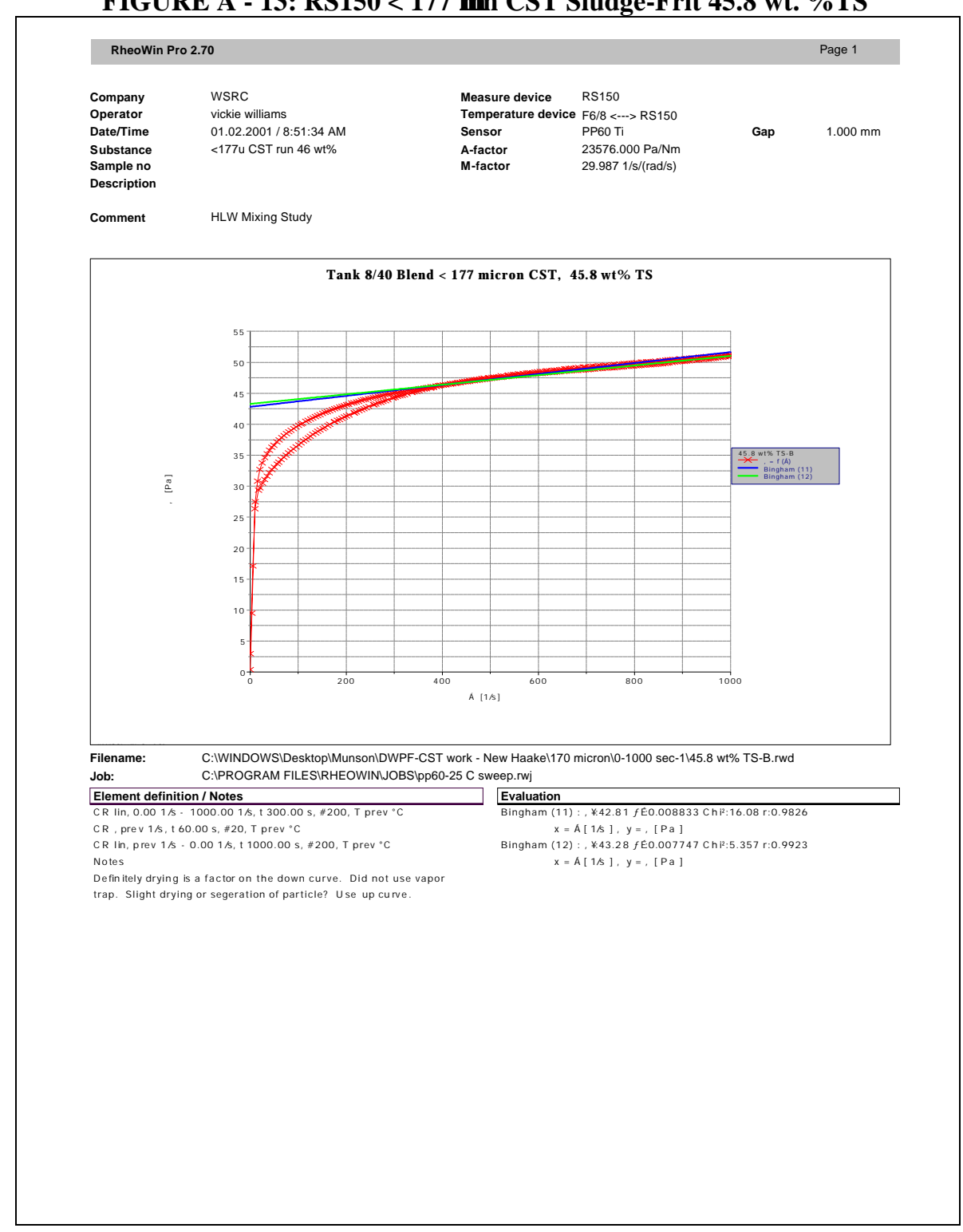




\section{APPENDIX}

WSRC-TR-2001-00069

Page A-10 of A - 23

\section{FIGURE A - 14: RS150 < $177 \mu$ m CST Sludge-Frit 48.4 wt. \% TS}

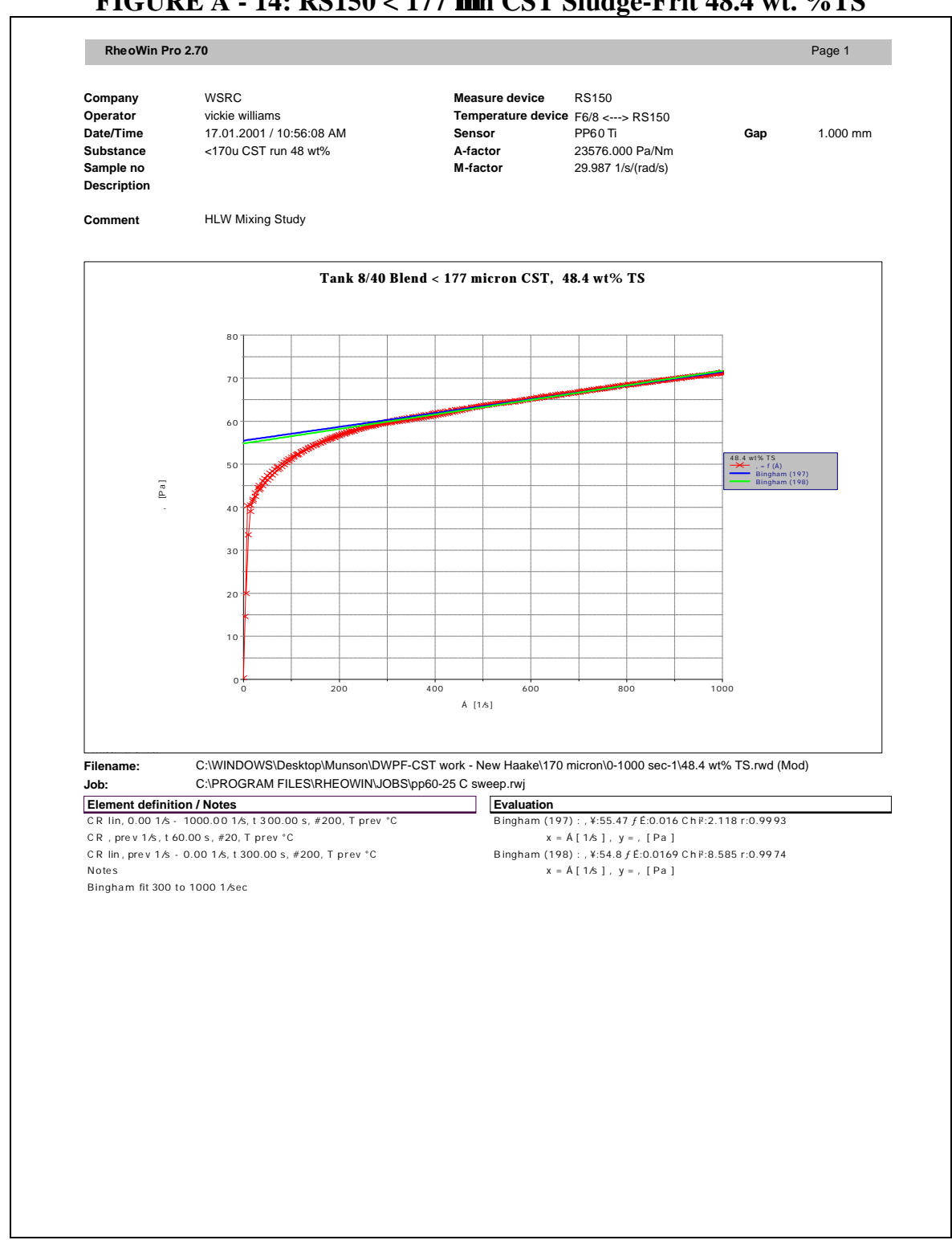

\section{FIGURE A - 15: RS150 < $177 \mu \mathrm{m}$ CST Sludge-Frit 52.2 wt. \% TS}

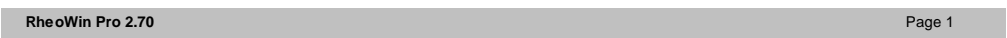

\begin{tabular}{|c|c|c|c|c|}
\hline $\begin{array}{l}\text { Company } \\
\text { Operator } \\
\text { Datertime } \\
\text { Substance }\end{array}$ & $\begin{array}{l}\text { WSRC } \\
\text { vickie williams } \\
\text { 17.01.2001/12:07:03 PM } \\
<170 \text { CST run } 50 \text { wt\% }\end{array}$ & $\begin{array}{l}\text { Measure device } \\
\text { Temperature device } \\
\text { Sensor } \\
\text { A-factor } \\
\text { M-factor }\end{array}$ & $\begin{array}{l}\text { RS150 } \\
\text { F6/8 } \ldots \rightarrow \text { RS150 } \\
\text { PP60 TI } \\
23576.000 \text { Pa/Nm }\end{array}$ & Gap \\
\hline
\end{tabular}

Comment HLW Mixing Study

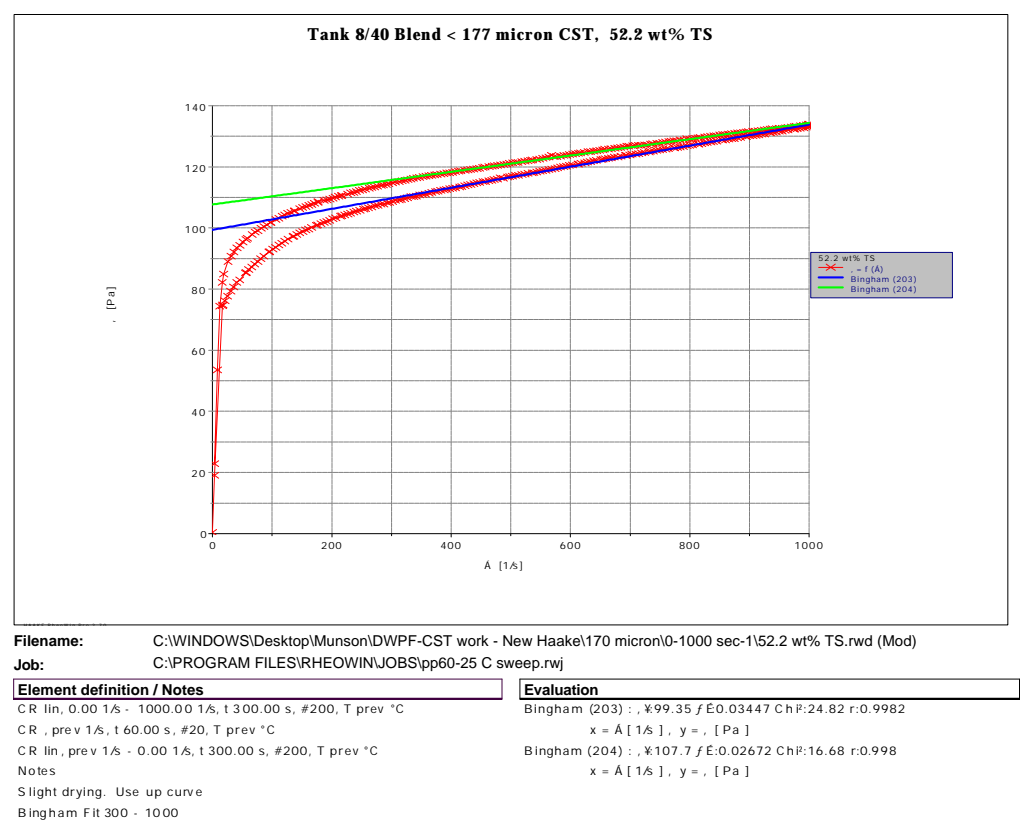




\section{APPENDIX}

WSRC-TR-2001-00069

Page A-11 of A - 23

FIGURE A - 16: RS150 < $30 \mu \mathrm{m}$ CST Sludge-Frit 39.1 wt. \% TS

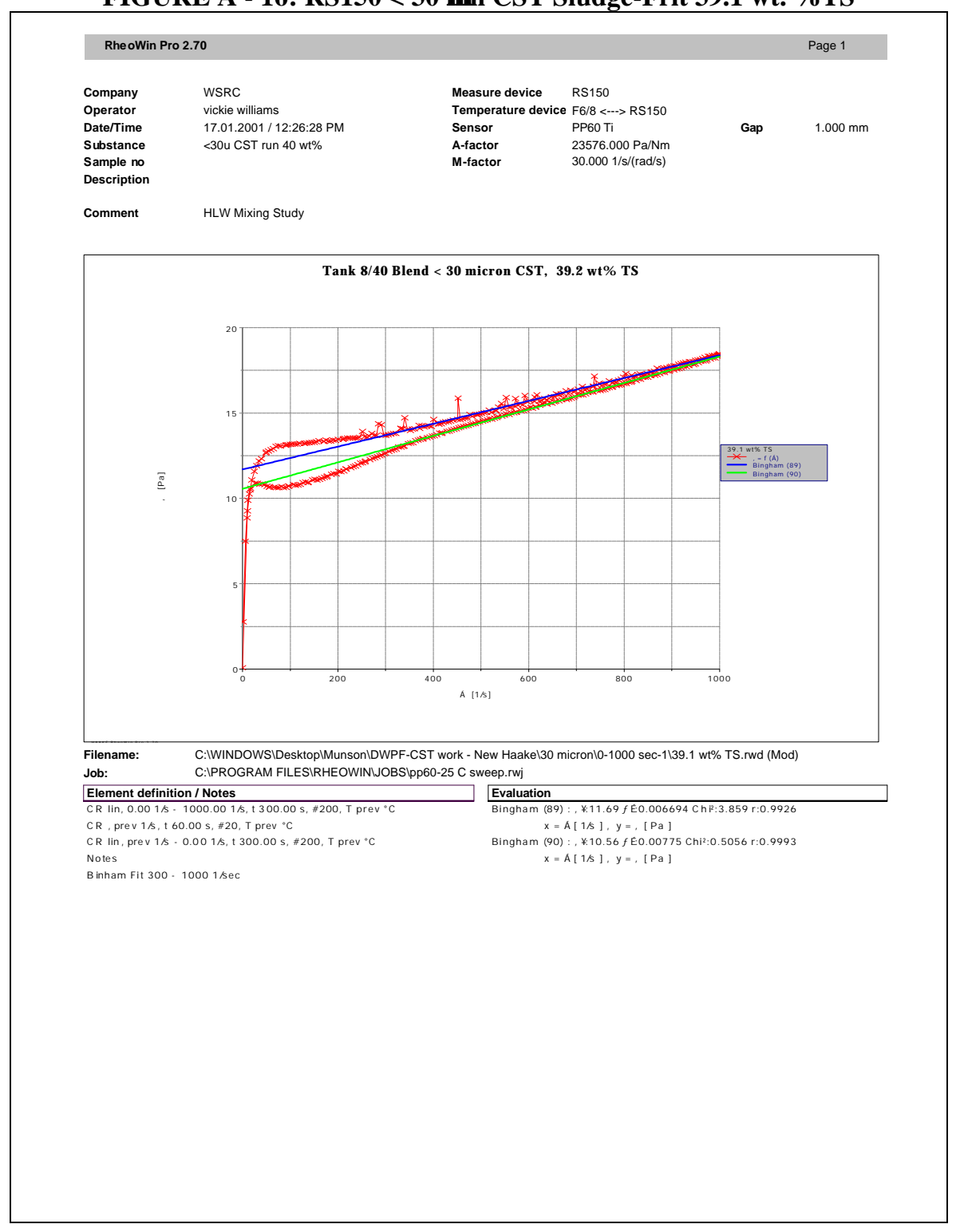

\section{FIGURE A - 17: RS150 < $30 \mu \mathrm{m}$ CST Sludge-Frit 41.0 wt. \% TS}

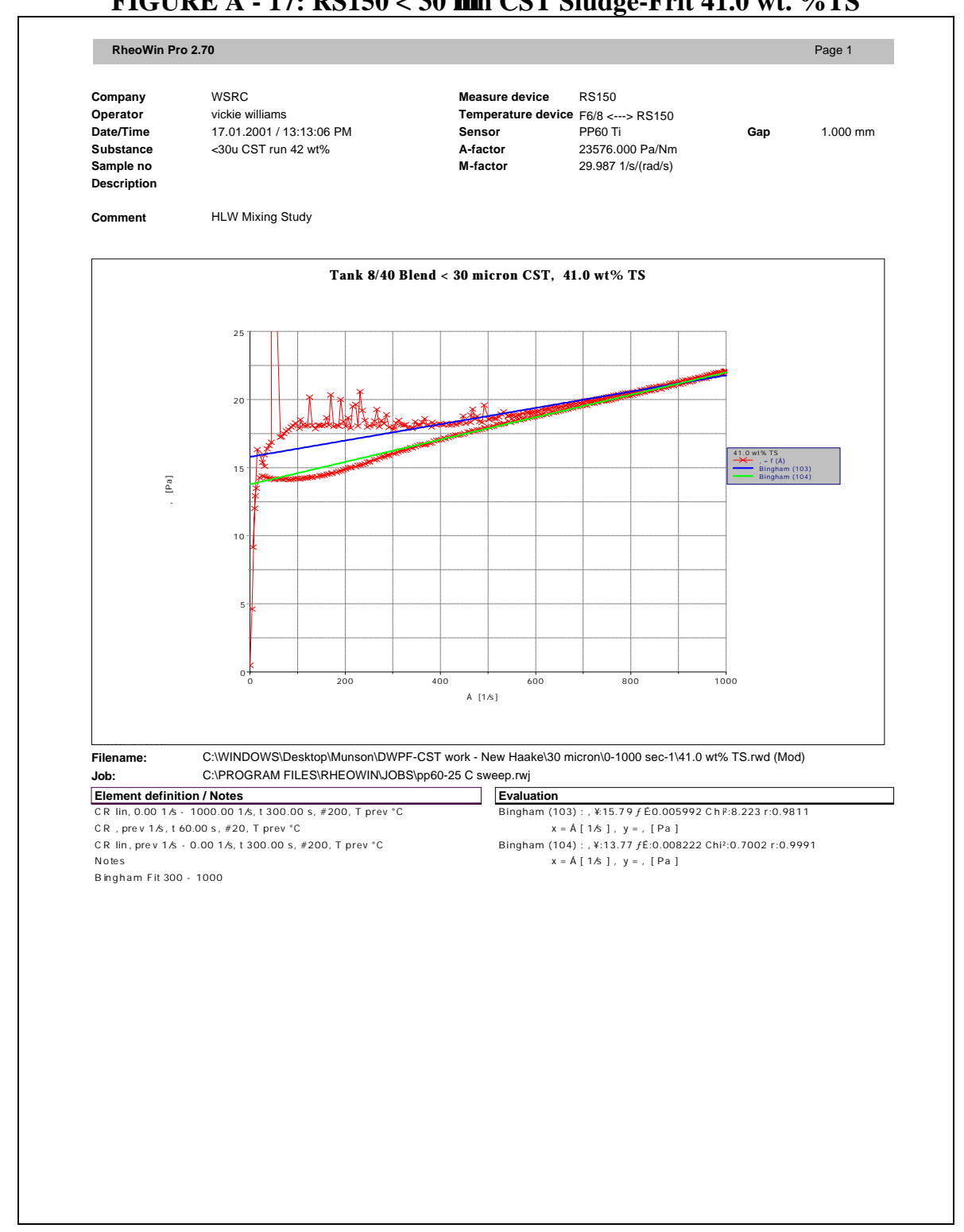




\section{APPENDIX}

WSRC-TR-2001-00069

Page A-12 of A - 23

FIGURE A - 18: RS150 < $30 \mu \mathrm{m}$ CST Sludge-Frit 43.2 wt. \% TS

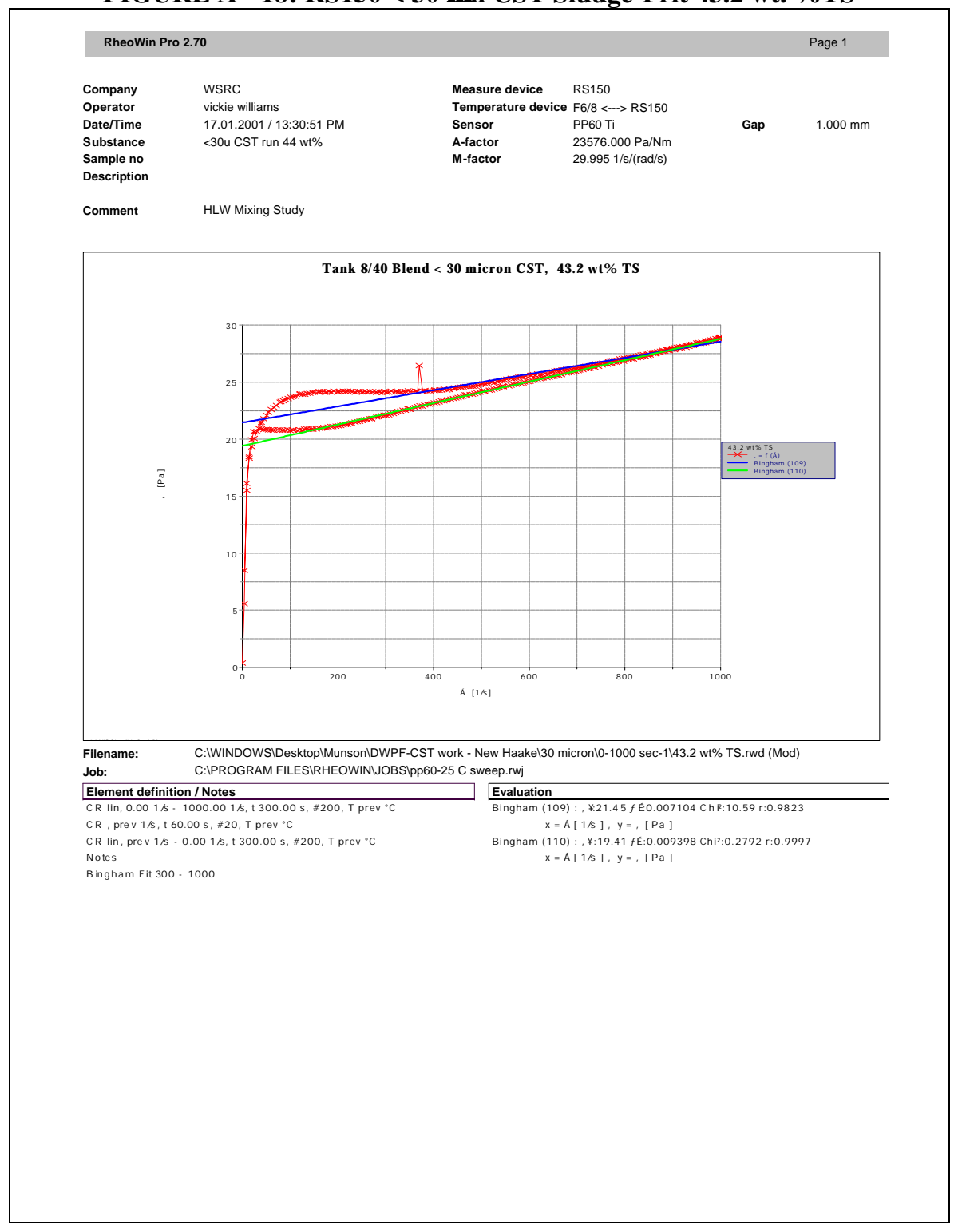

FIGURE A - 19: RS150 < $30 \mu \mathrm{m}$ CST Sludge-Frit 45.2 wt. \% TS

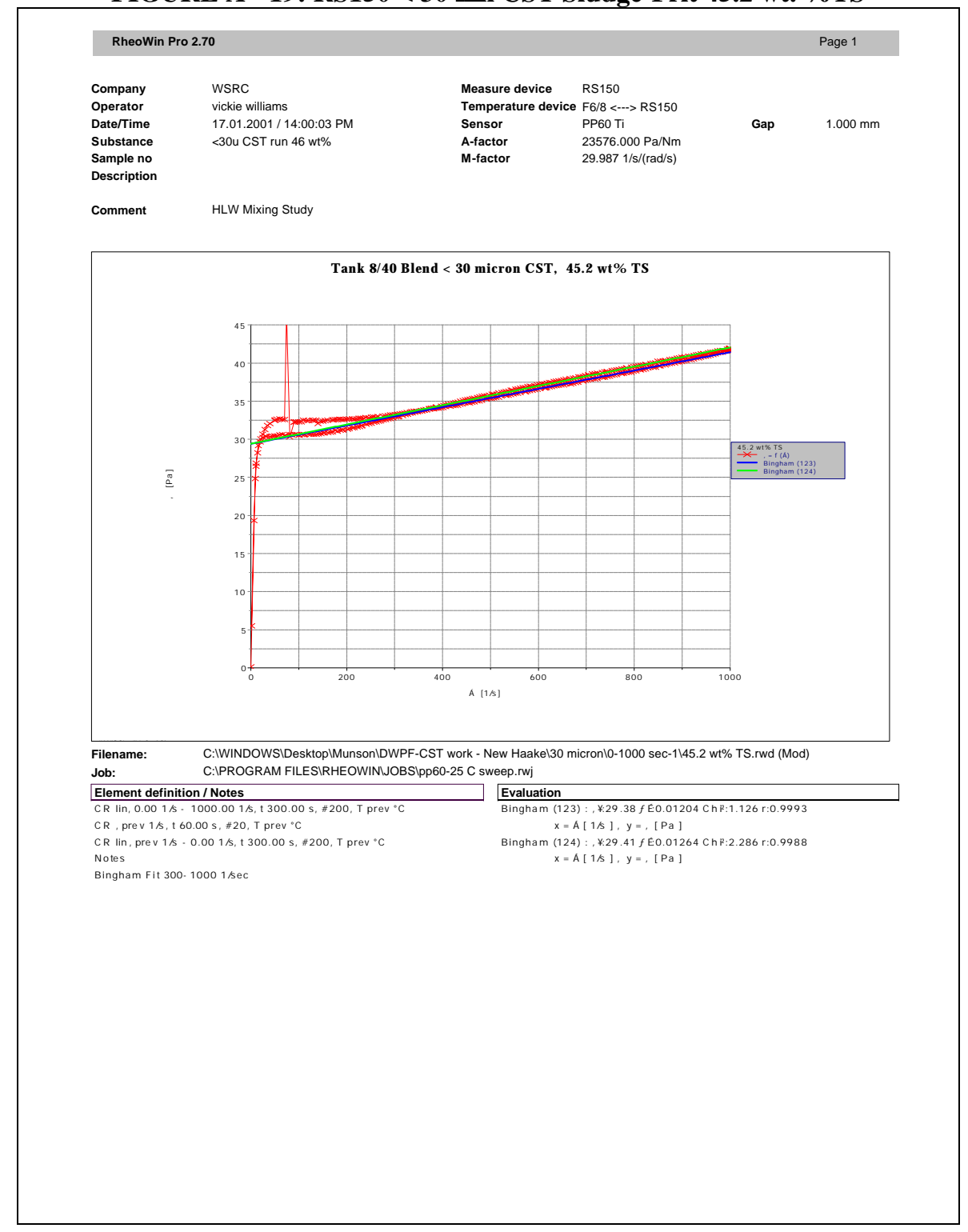




\section{APPENDIX}

WSRC-TR-2001-00069

Page A-13 of A - 23

FIGURE A - 20: RS150 < $30 \mu \mathrm{m}$ CST Sludge-Frit 47.3 wt. \% TS

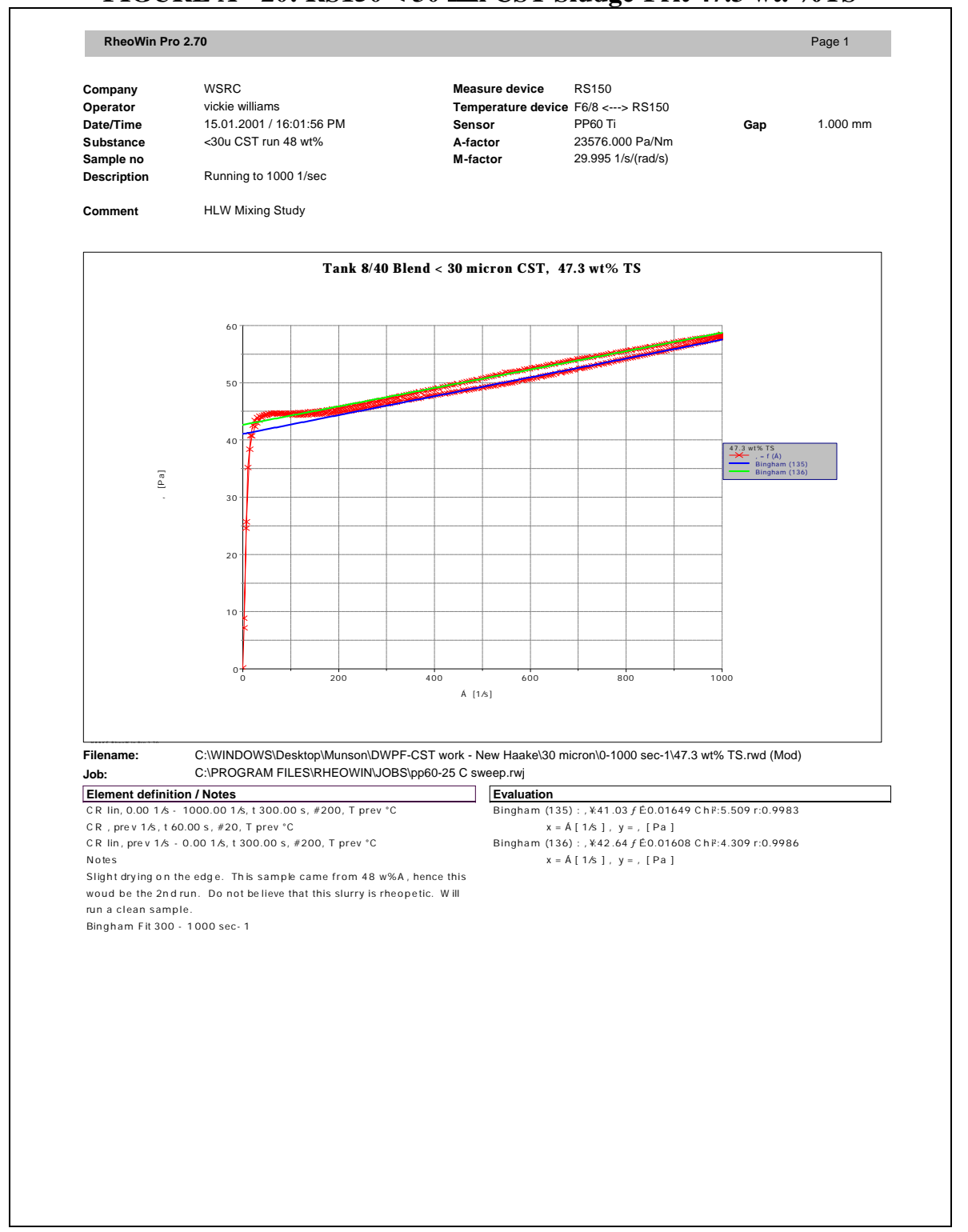

FIGURE A - 21: RS150 < $30 \mu \mathrm{m}$ CST Sludge-Frit 48.9 wt. \% TS

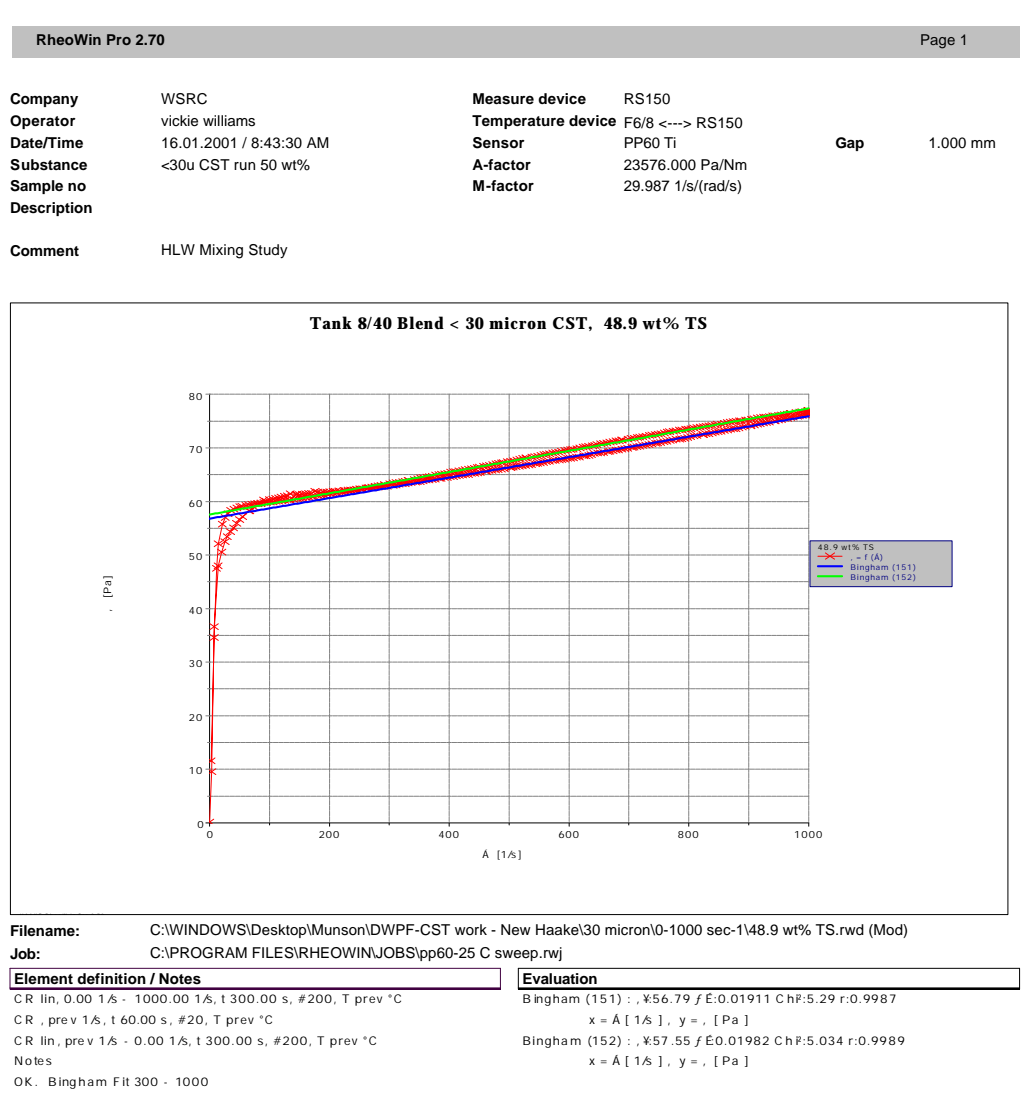


WSRC-TR-2001-00069

APPENDIX

Page A - 14 of A - 23

FIGURE A - 22: RV20 Sludge-Frit-Only 39.2 wt. \% TS

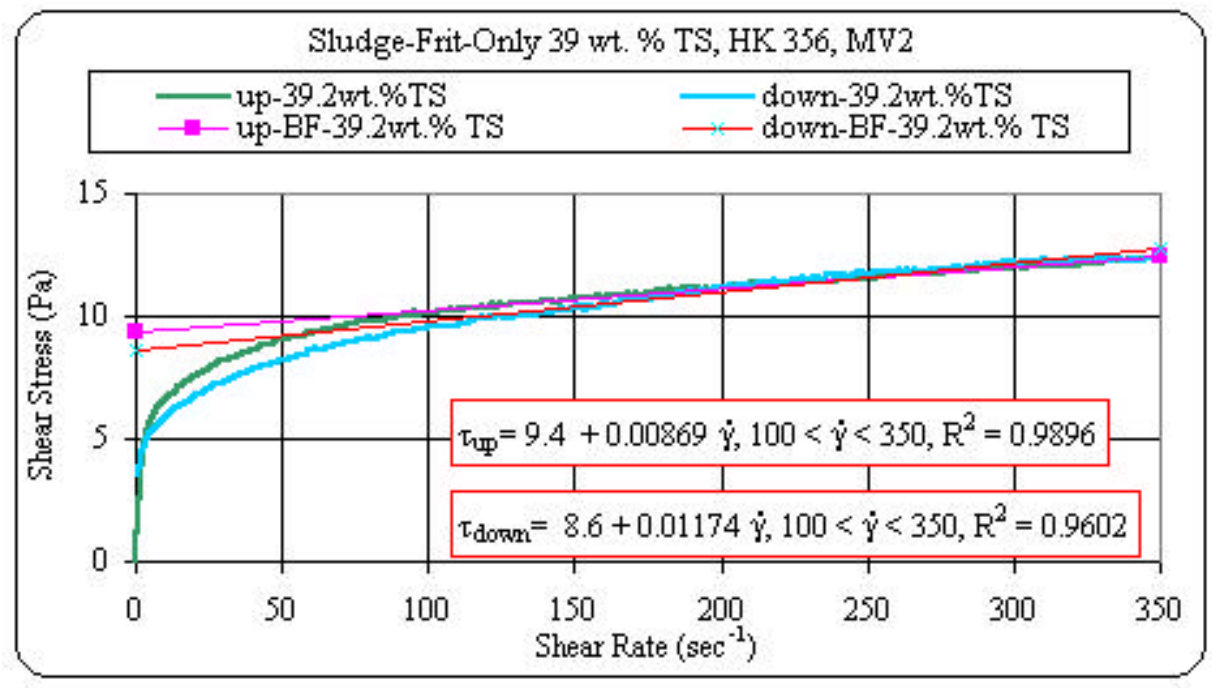

FIGURE A - 23: RV20 Sludge-Frit-Only 40.9 wt. \% TS

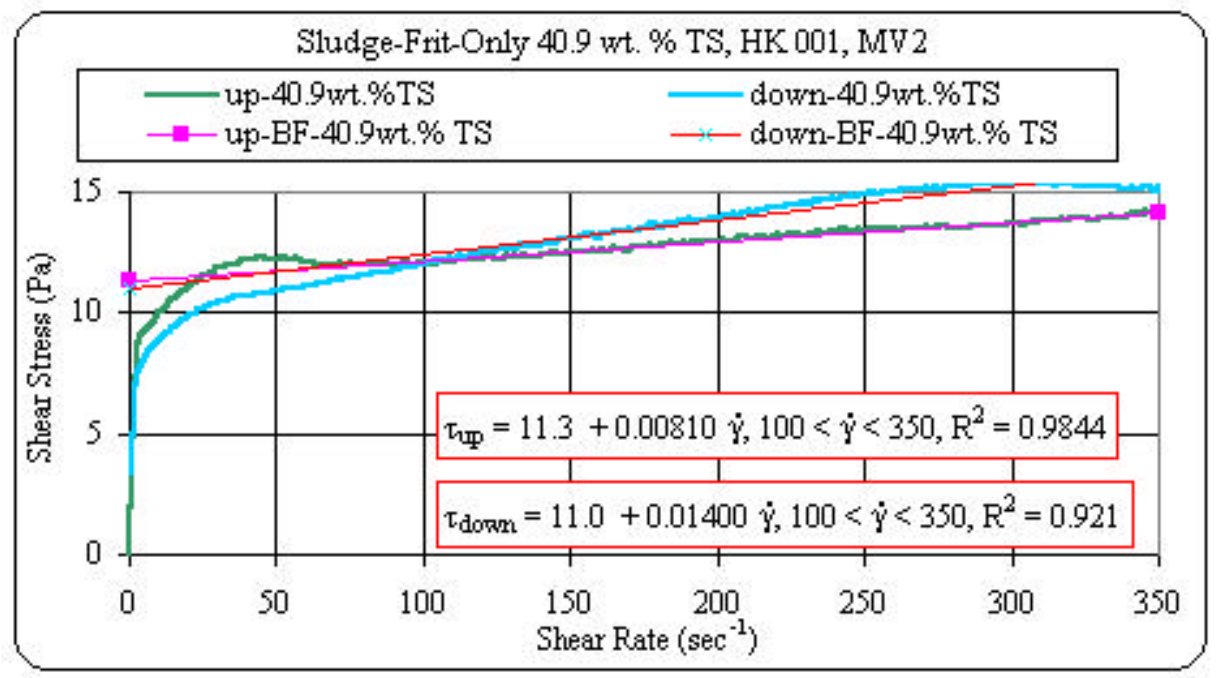

FIGURE A - 24: RV20 Sludge-Frit-Only 43.3 wt. \% TS

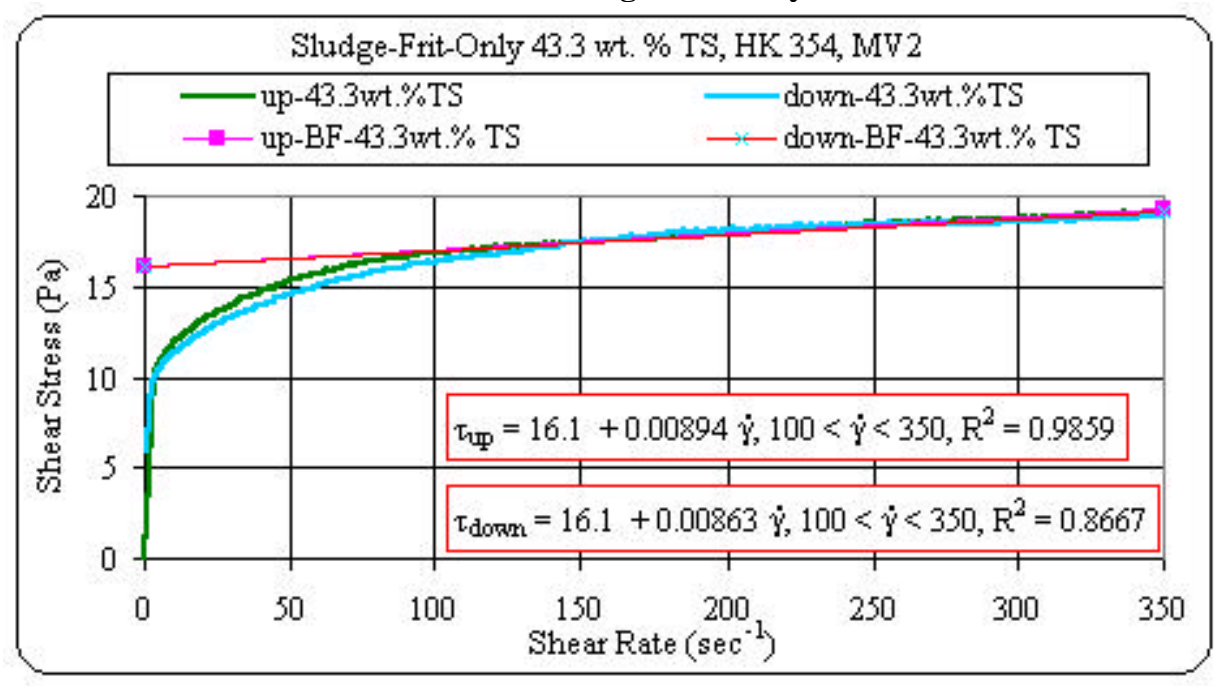


WSRC-TR-2001-00069

APPENDIX

Page A - 15 of A - 23

FIGURE A - 25: RV20 Sludge-Frit-Only 46.1 wt. \% TS

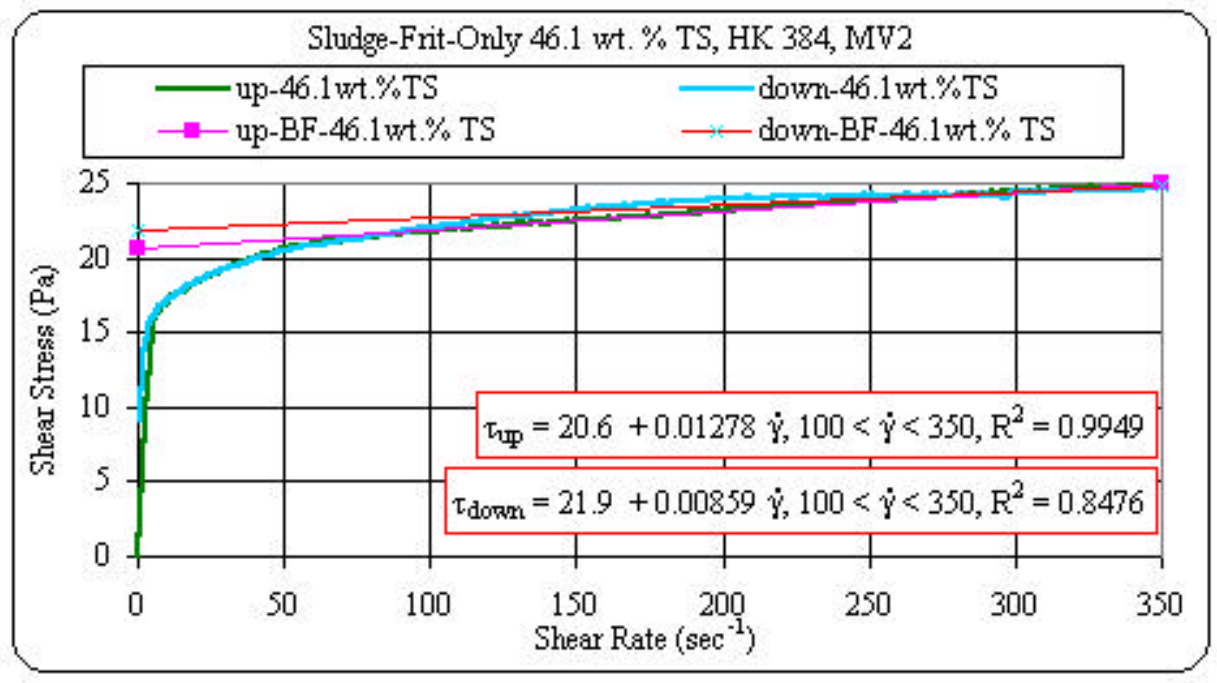

FIGURE A - 26: RV20 Sludge-Frit-Only 47.7 wt. \% TS

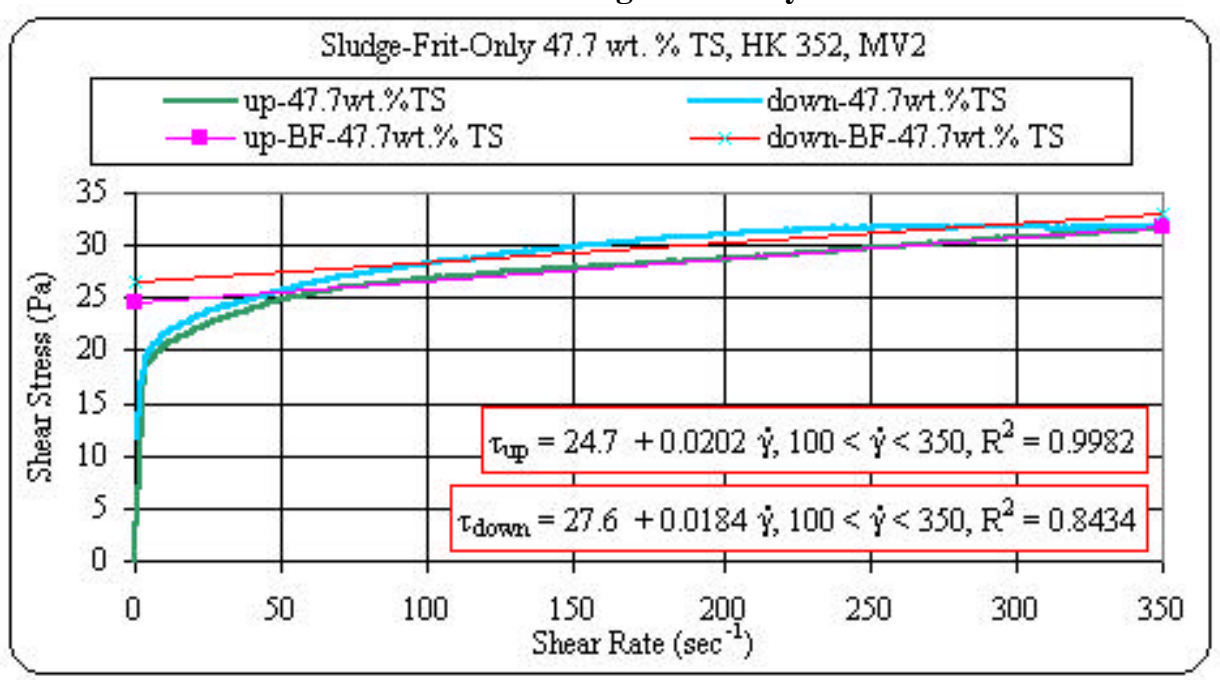

FIGURE A - 27: RV20 Sludge-Frit-Only 52.1 wt. \% TS

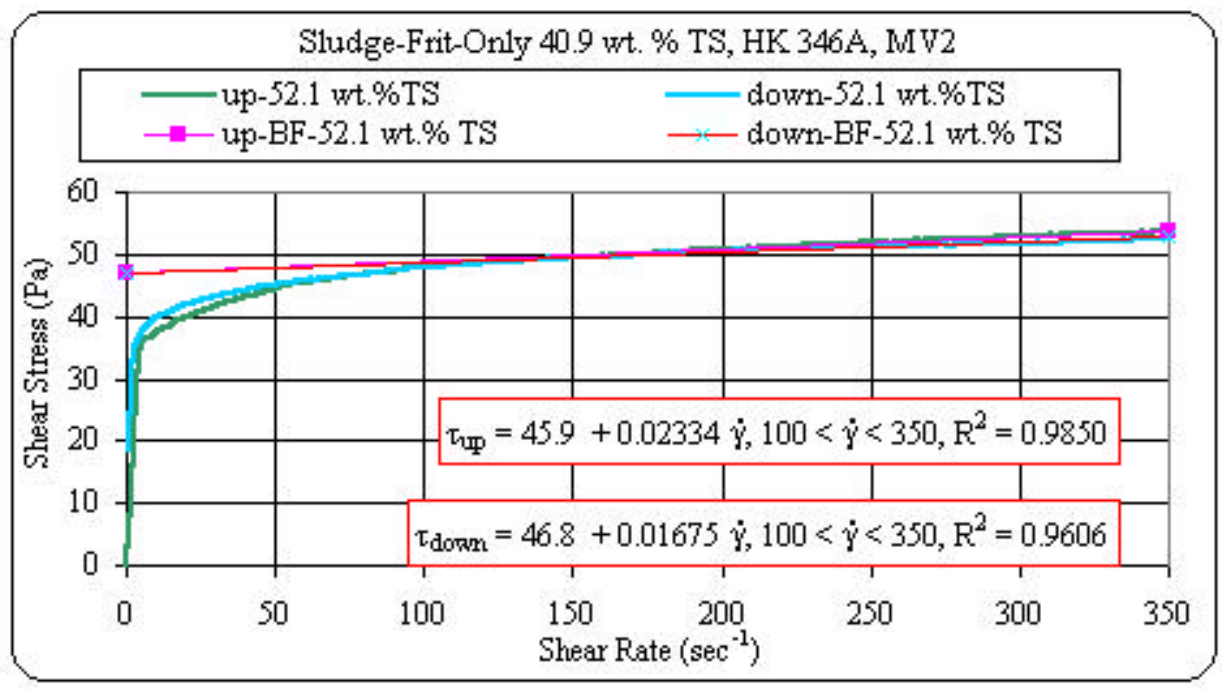


WSRC-TR-2001-00069

APPENDIX

Page A - 16 of A - 23

FIGURE A - 28: RV20 < $177 \mu$ m CST-Sludge-Frit 39.3 wt. \% TS

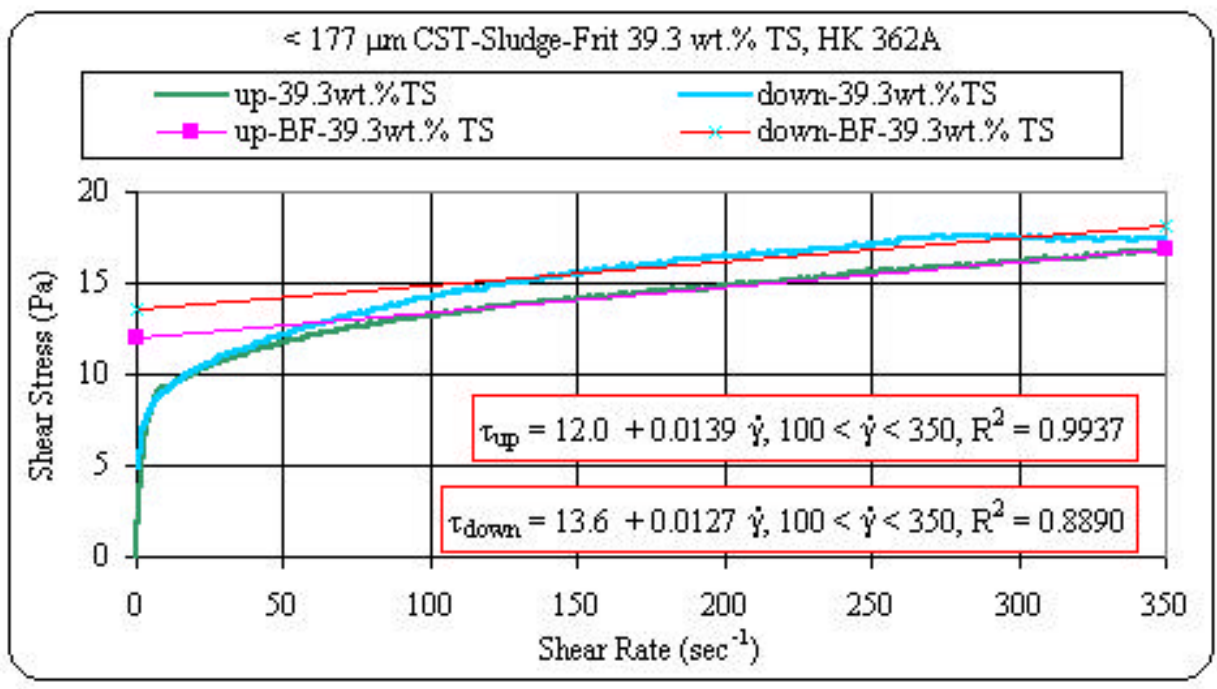

FIGURE A - 29: RV20 < $177 \mu$ m CST-Sludge-Frit 41.4 wt. \% TS

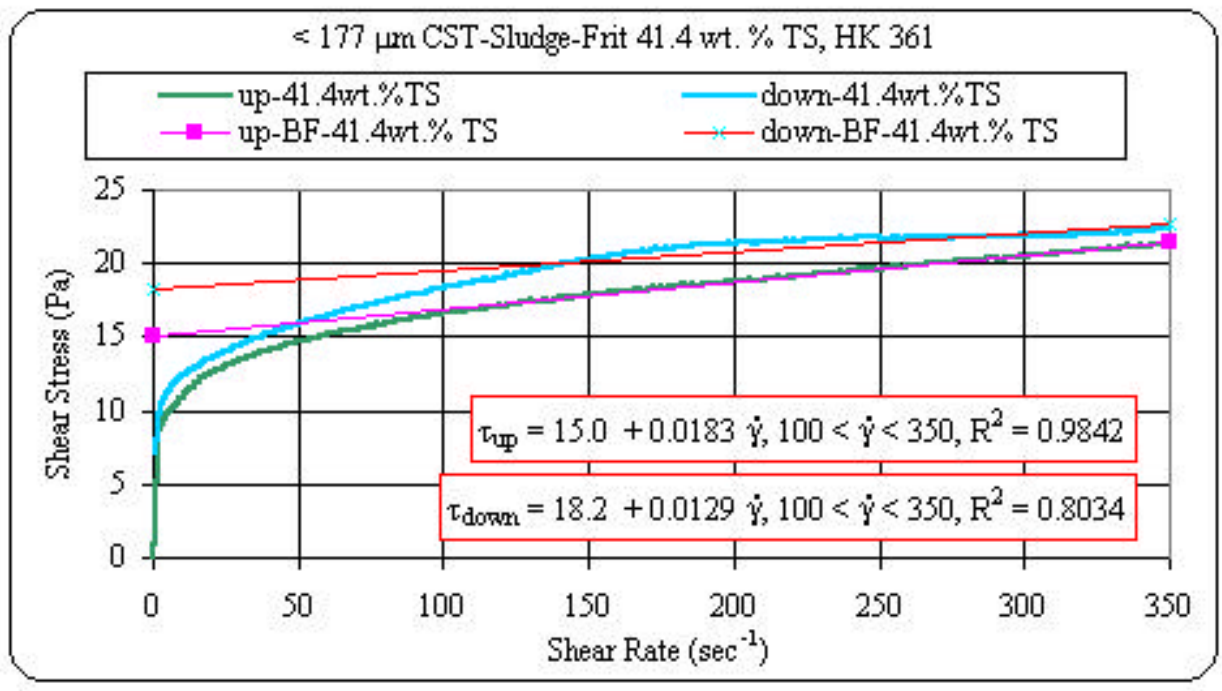

FIGURE A - 30: RV20 < $177 \mu$ m CST-Sludge-Frit 43.8 wt. \% TS

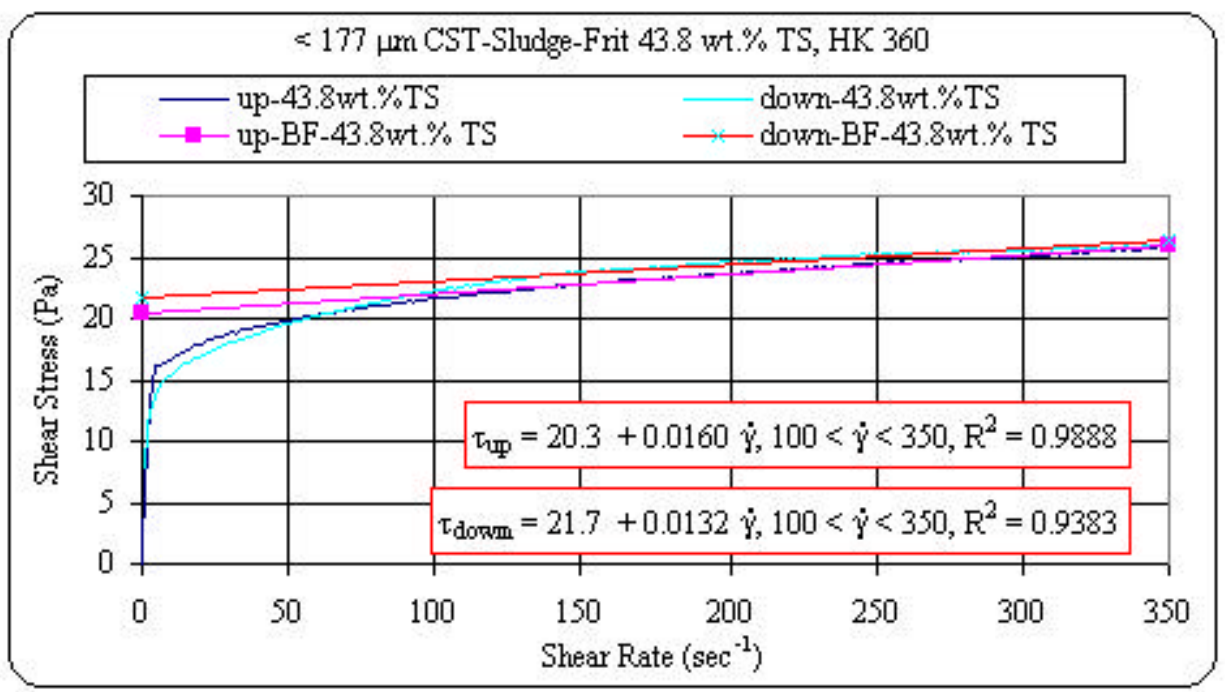


WSRC-TR-2001-00069

APPENDIX

Page A - 17 of A - 23

FIGURE A - 31: RV20 < $177 \mu$ m CST-Sludge-Frit 45.8 wt. \% TS

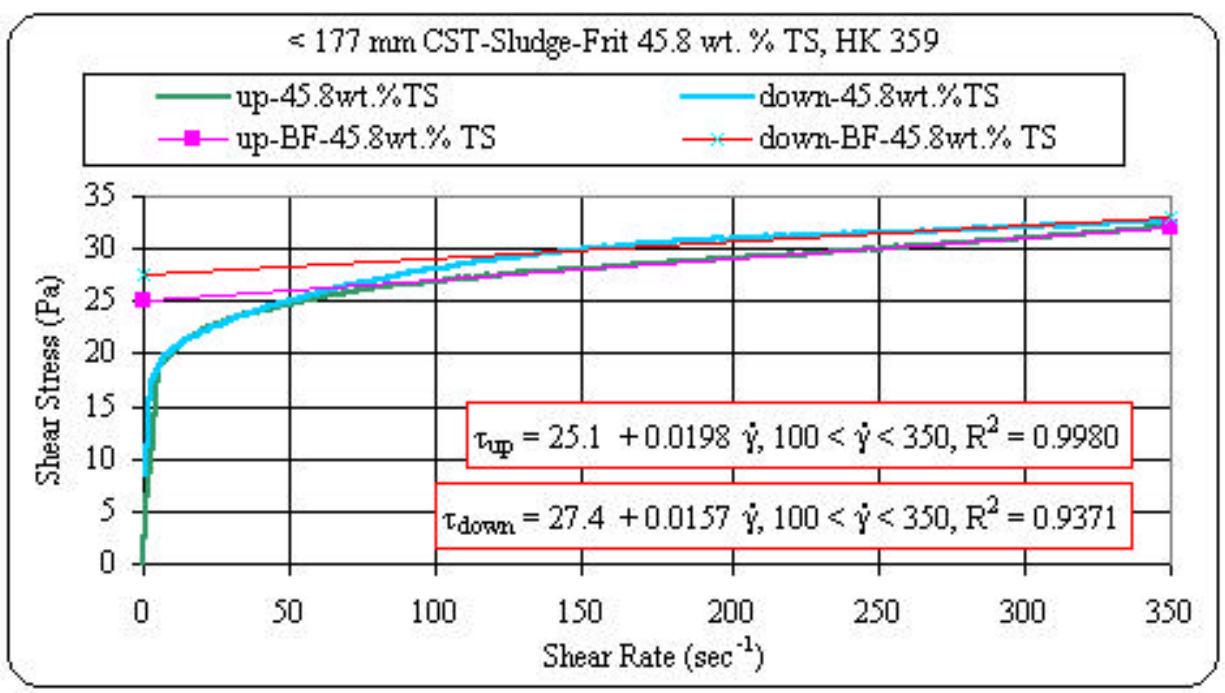

FIGURE A - 32: RV20 < $177 \mu$ m CST-Sludge-Frit 48.4 wt. \% TS

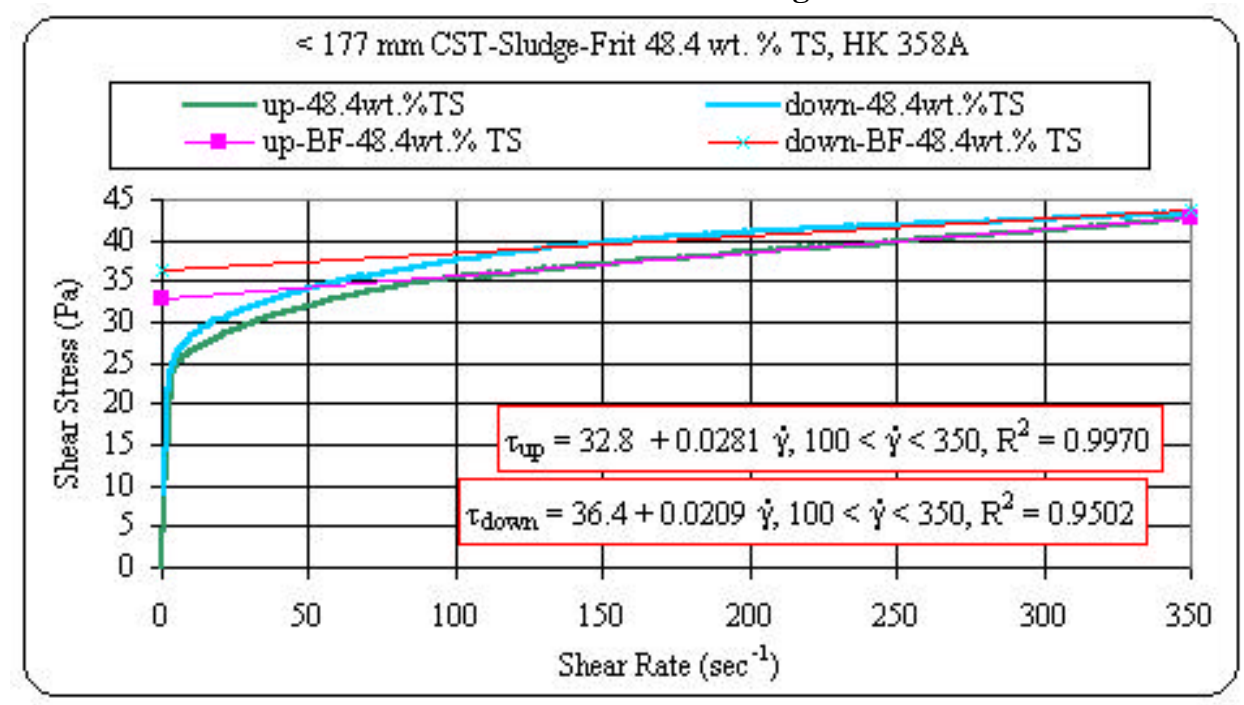

FIGURE A - 33: RV20 < $177 \mu$ m CST-Sludge-Frit 52.2 wt. \% TS

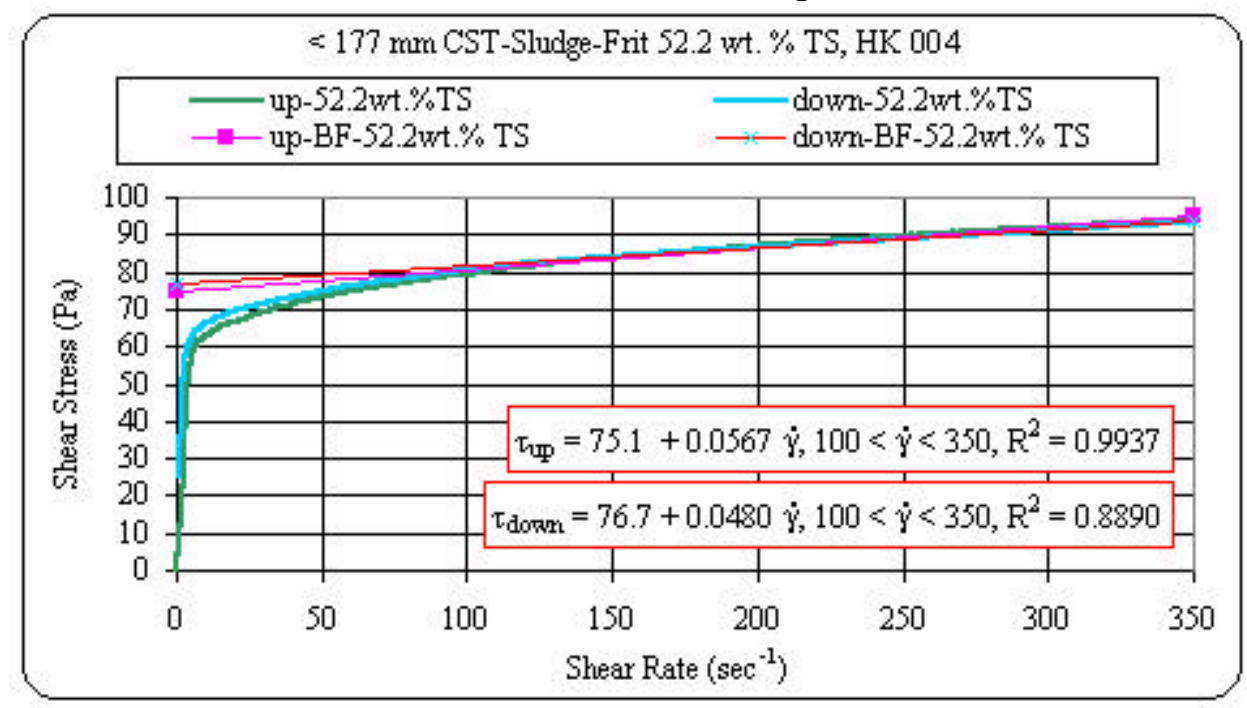


WSRC-TR-2001-00069

APPENDIX

Page A - 18 of A - 23

FIGURE A - 34: RV20 < $30 \mu \mathrm{m}$ CST-Sludge-Frit 39.1 wt. \% TS

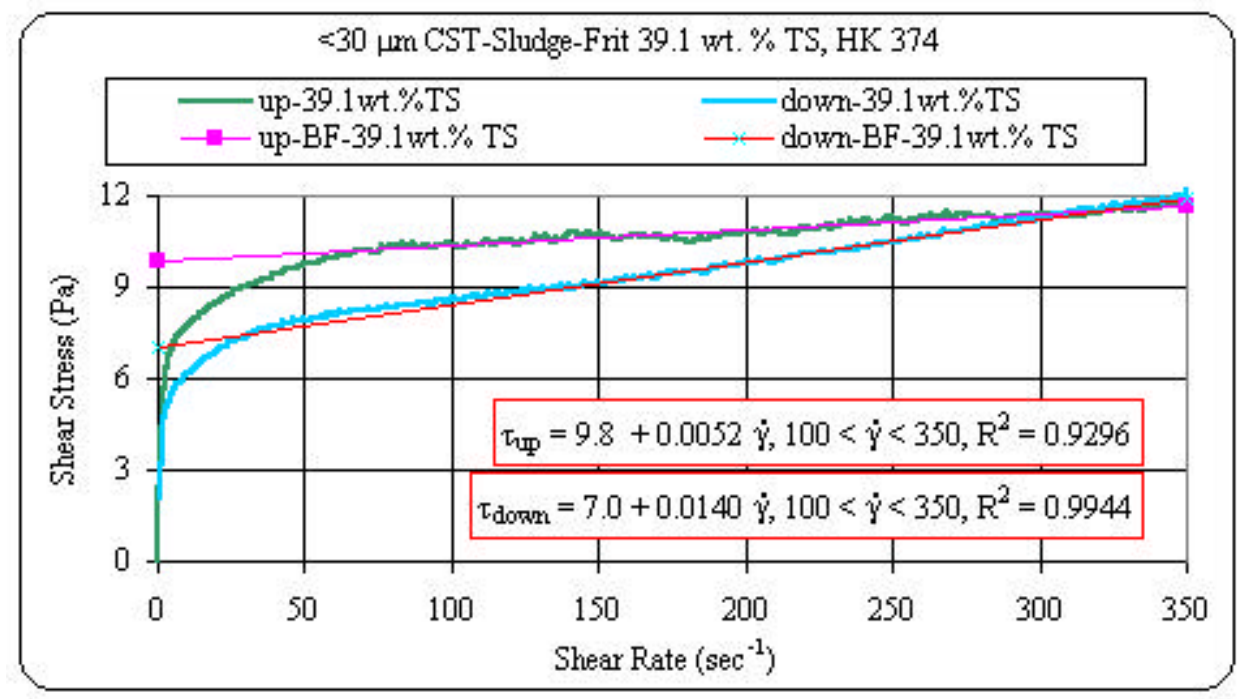

FIGURE A - 35: RV20 < $30 \mu \mathrm{m}$ CST-Sludge-Frit 41.0 wt. \% TS

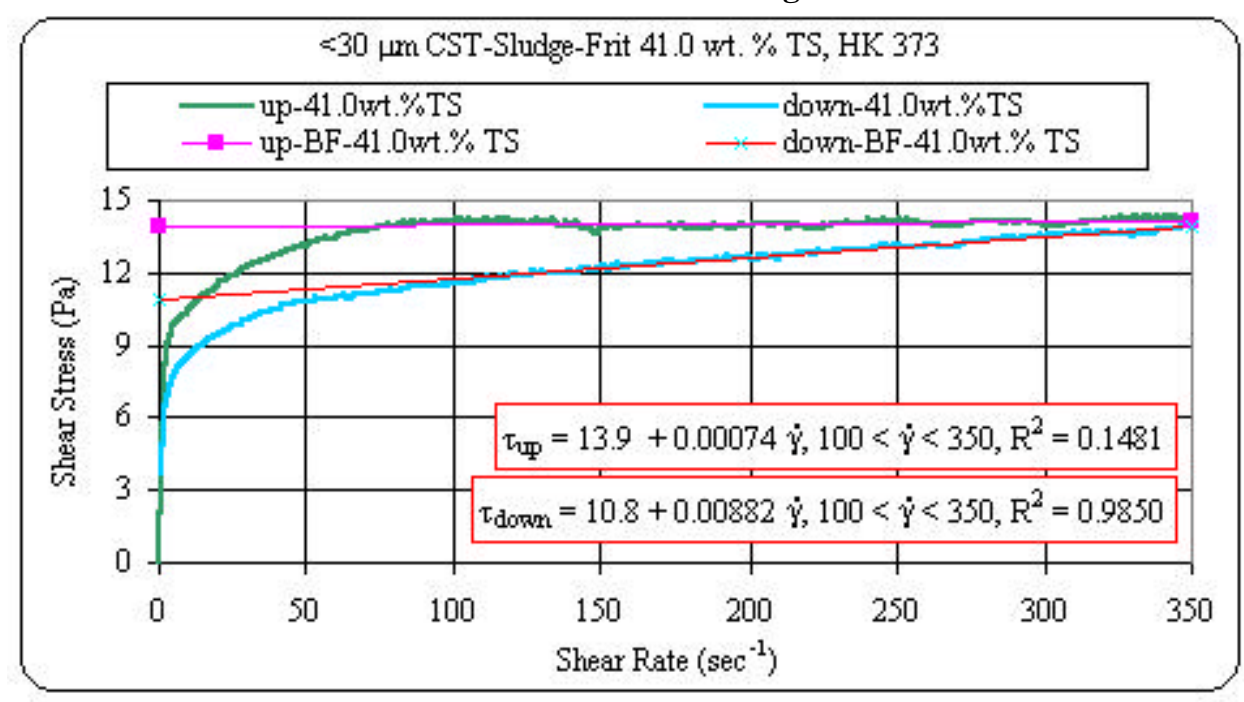

FIGURE A - 36: RV20 < $30 \mu \mathrm{m}$ CST-Sludge-Frit 43.2 wt. \% TS

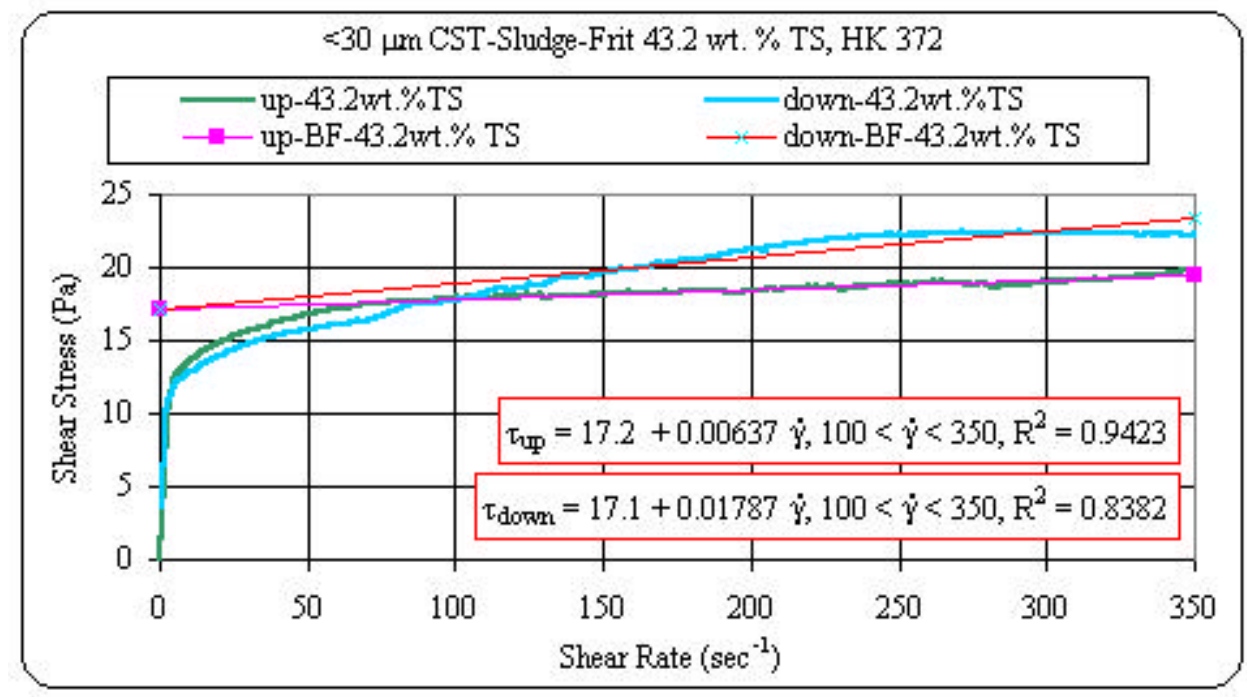


WSRC-TR-2001-00069

APPENDIX

Page A - 19 of A - 23

FIGURE A - 37: RV20 < $30 \mu \mathrm{m}$ CST-Sludge-Frit 45.2 wt. \% TS

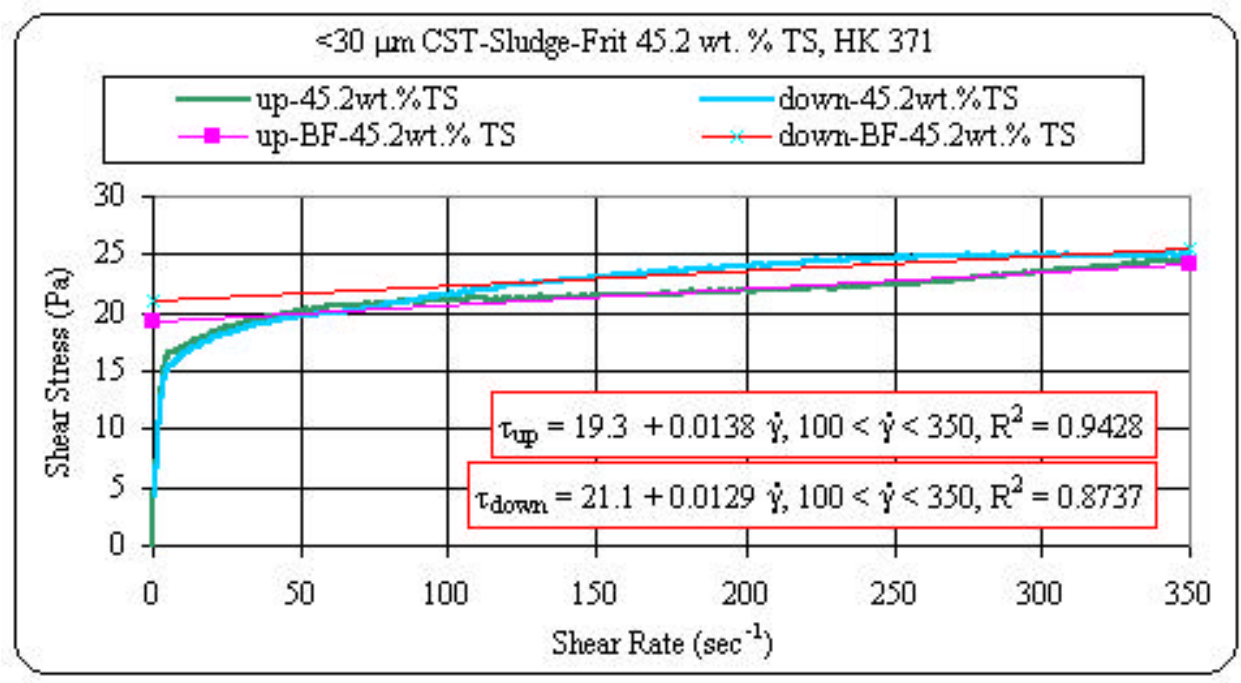

FIGURE A - 38: RV20 < $30 \mu \mathrm{m}$ CST-Sludge-Frit 47.3 wt. \% TS

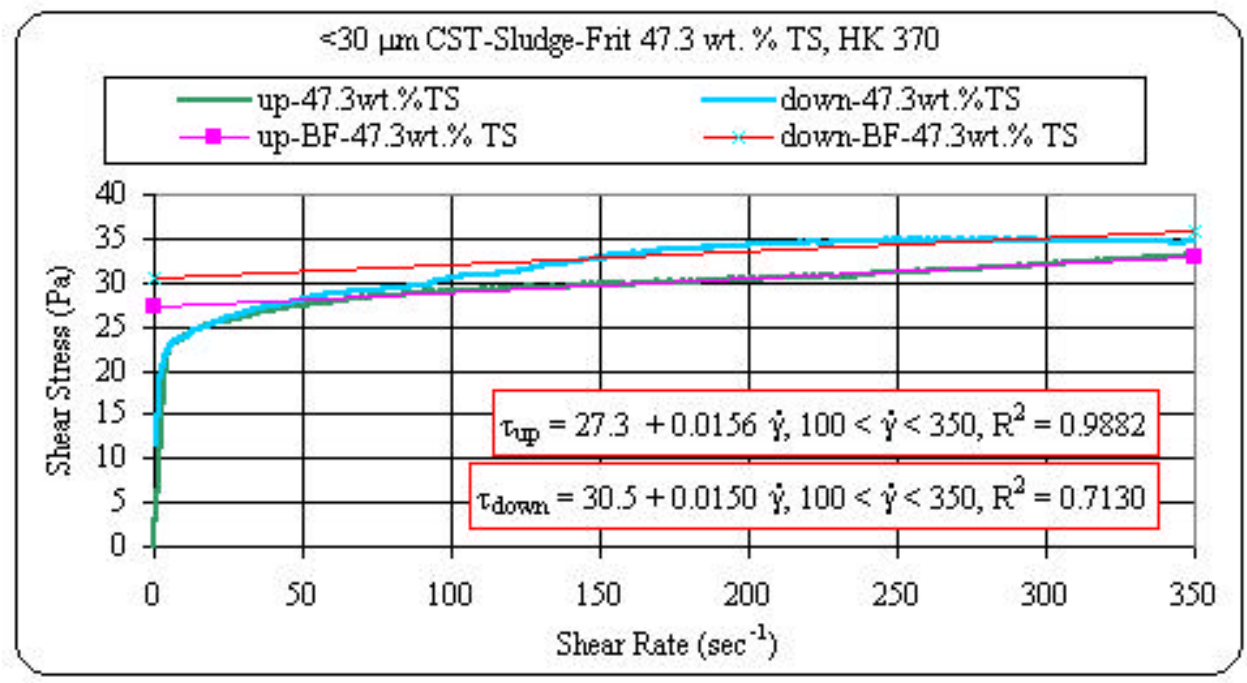

FIGURE A - 39: RV20 < $30 \mu \mathrm{m}$ CST-Sludge-Frit 48.9 wt. $\%$ TS

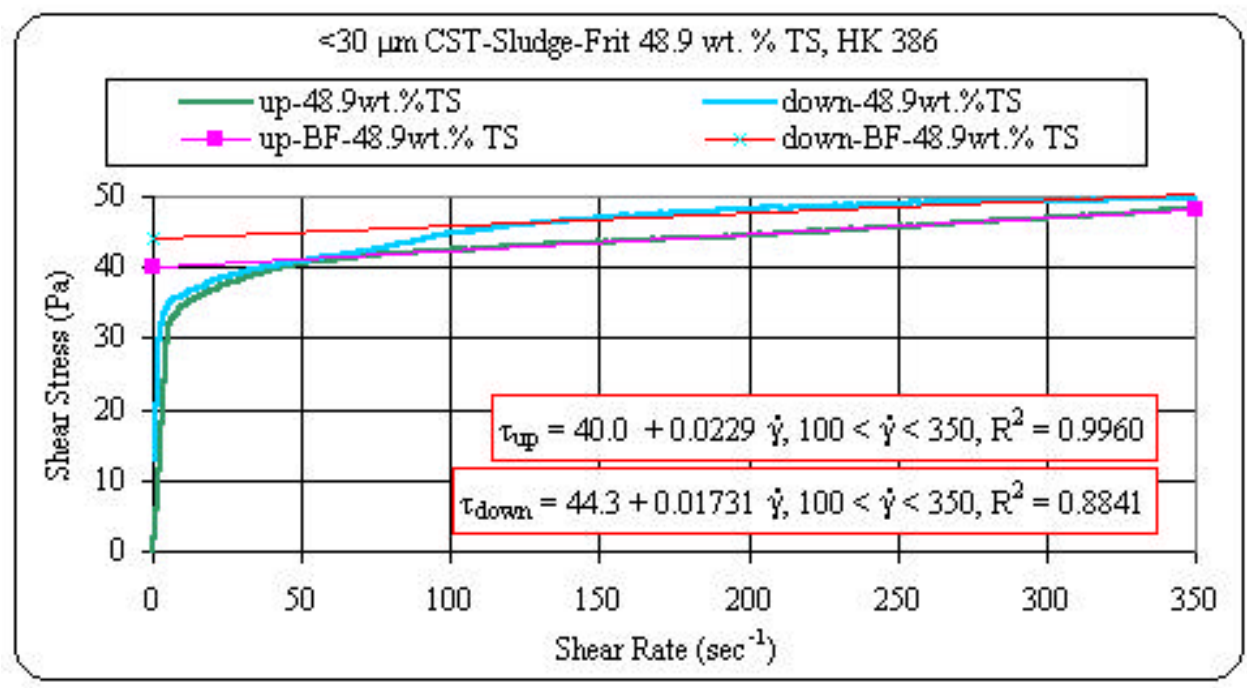


FIGURE A - 40: Particle Size Distribution Sludge-Frit-Only \#1

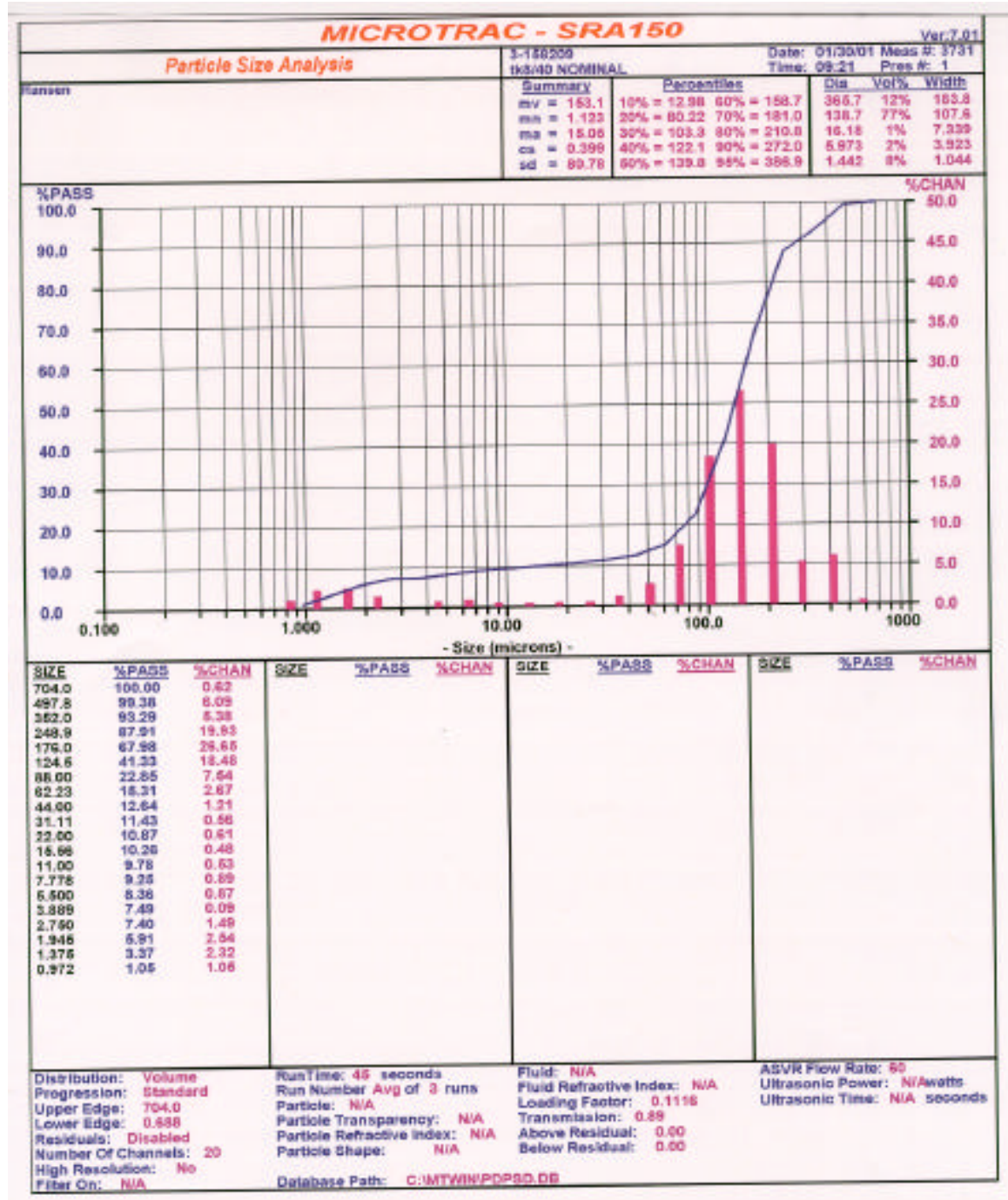

FIGURE A - 41: Particle Size Distribution Sludge-Frit-Only \#2

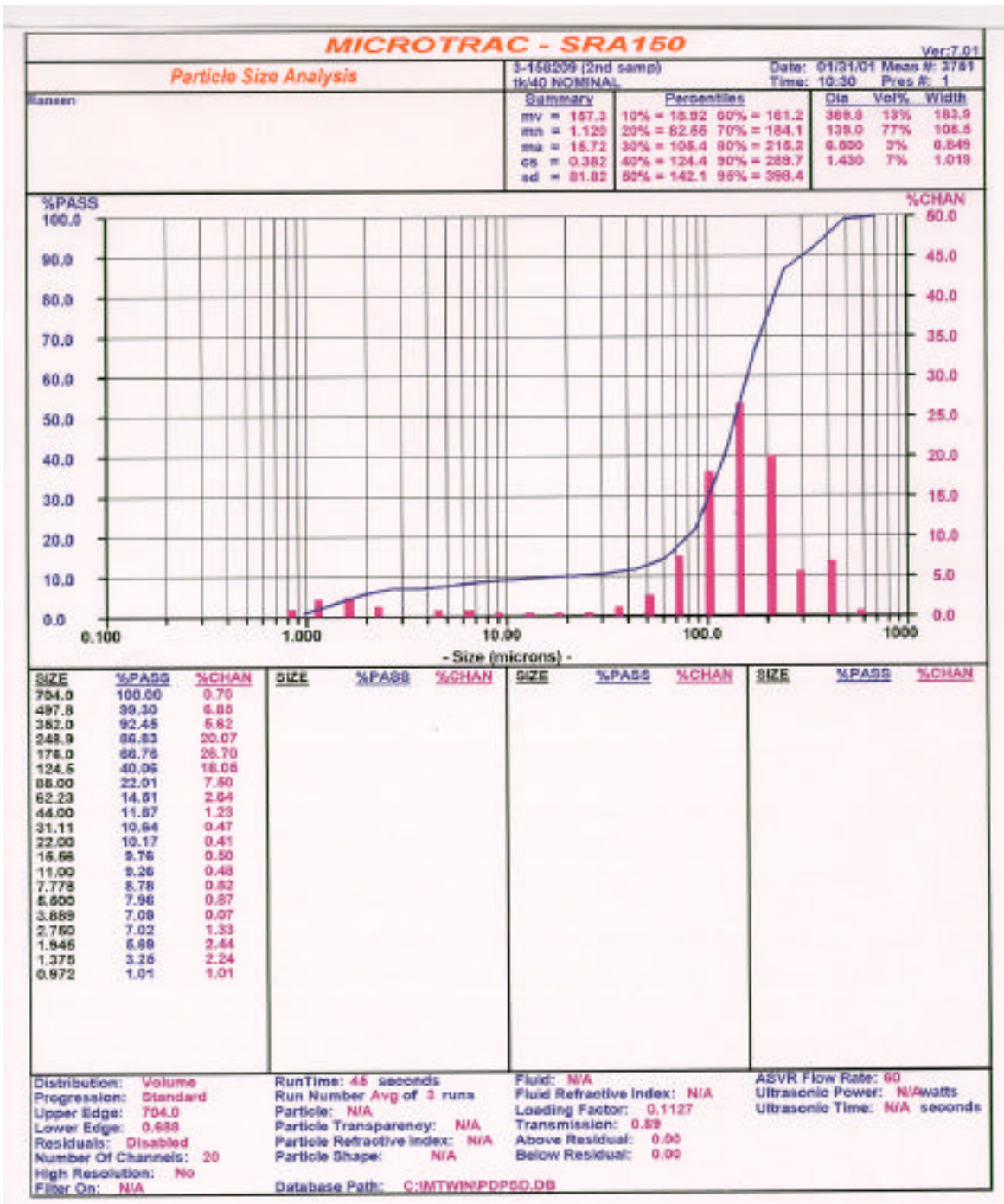


FIGURE A - 42: Particle Size Distribution < $177 \mu \mathrm{m}$ CST-Sludge-Frit \#1

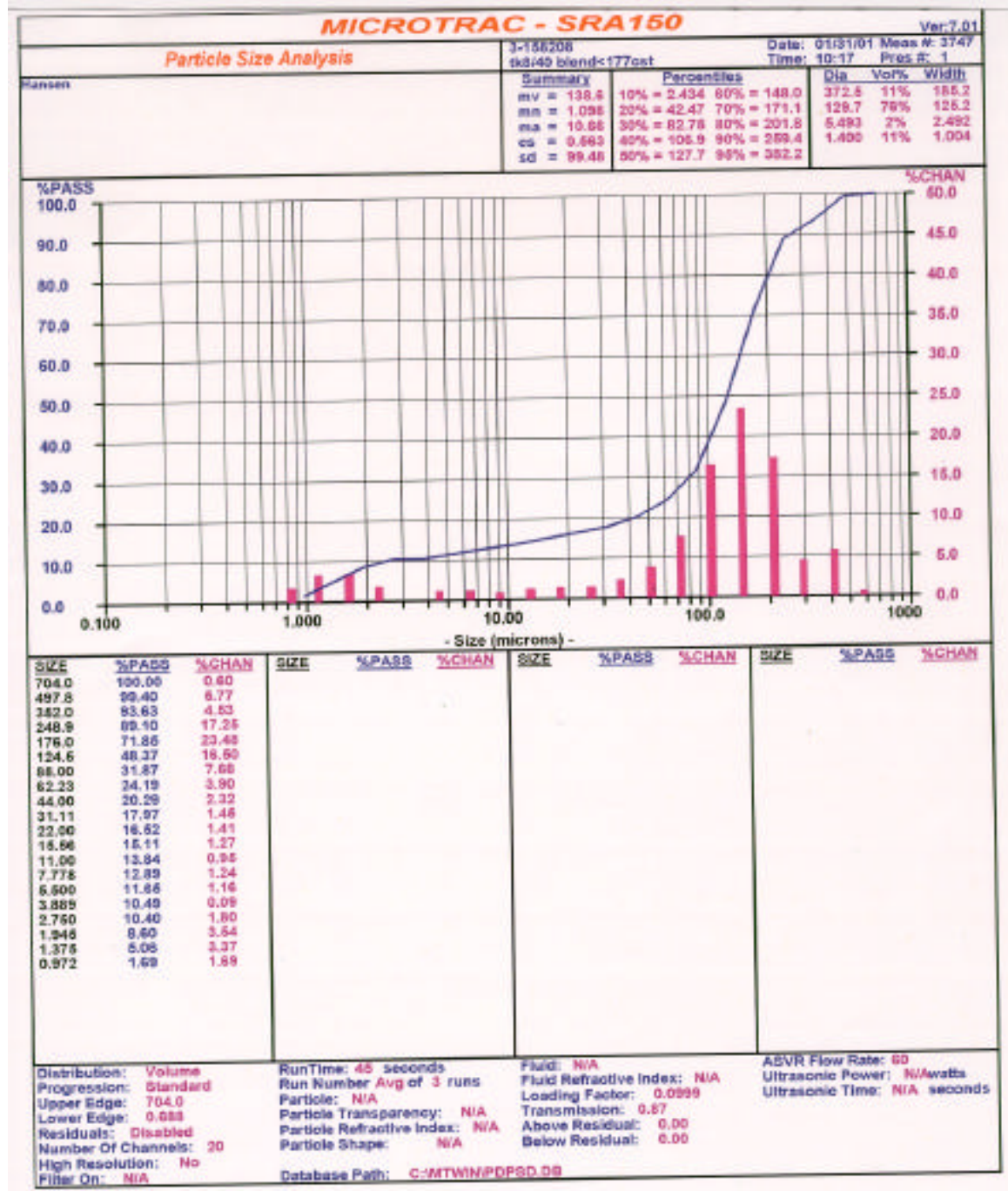

FIGURE A - 43: Particle Size Distribution < $177 \mu \mathrm{m}$ CST-Sludge-Frit \#2

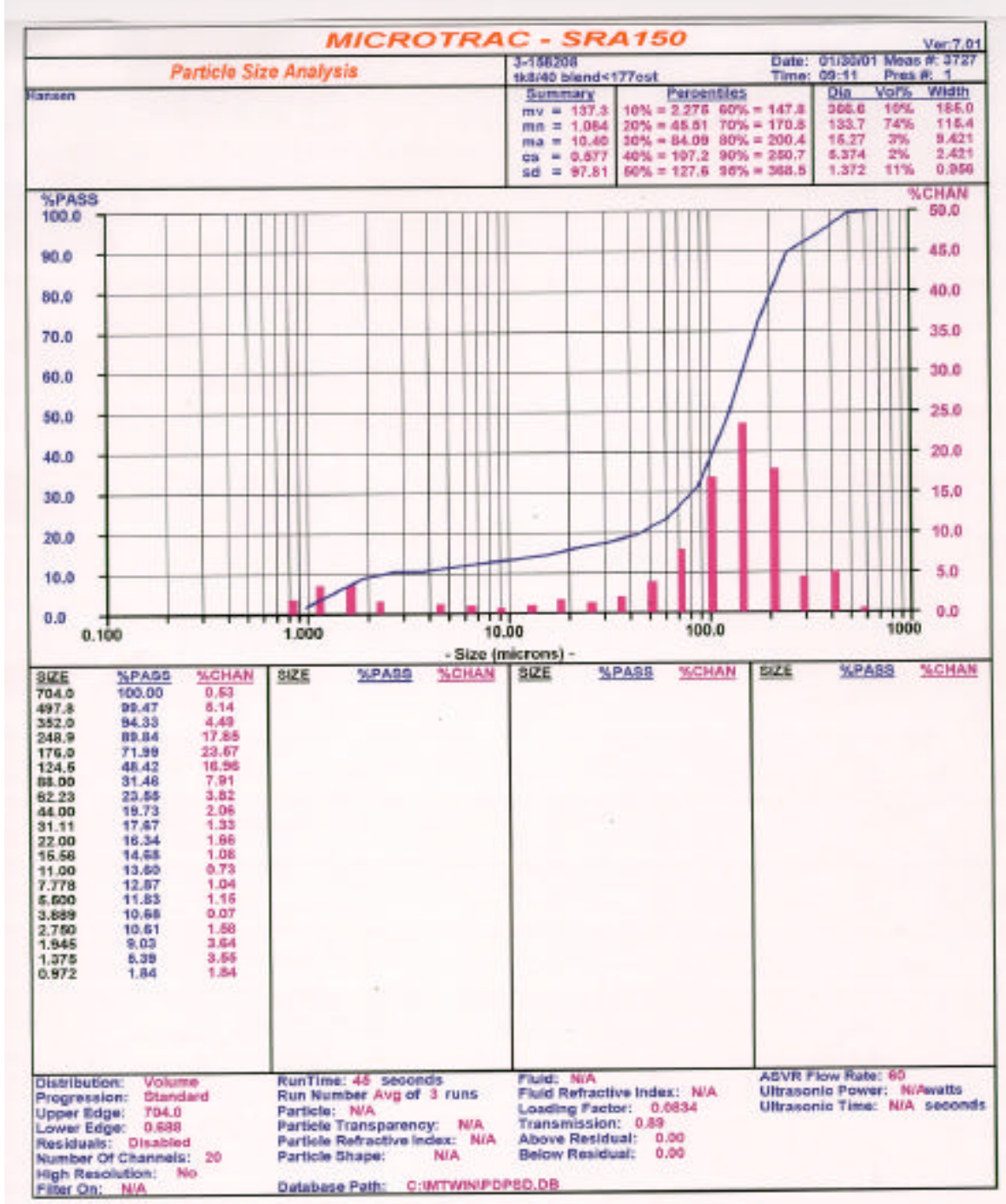


FIGURE A - 44: Particle Size Distribution < $30 \mu \mathrm{m}$ CST-Sludge-Frit \#1

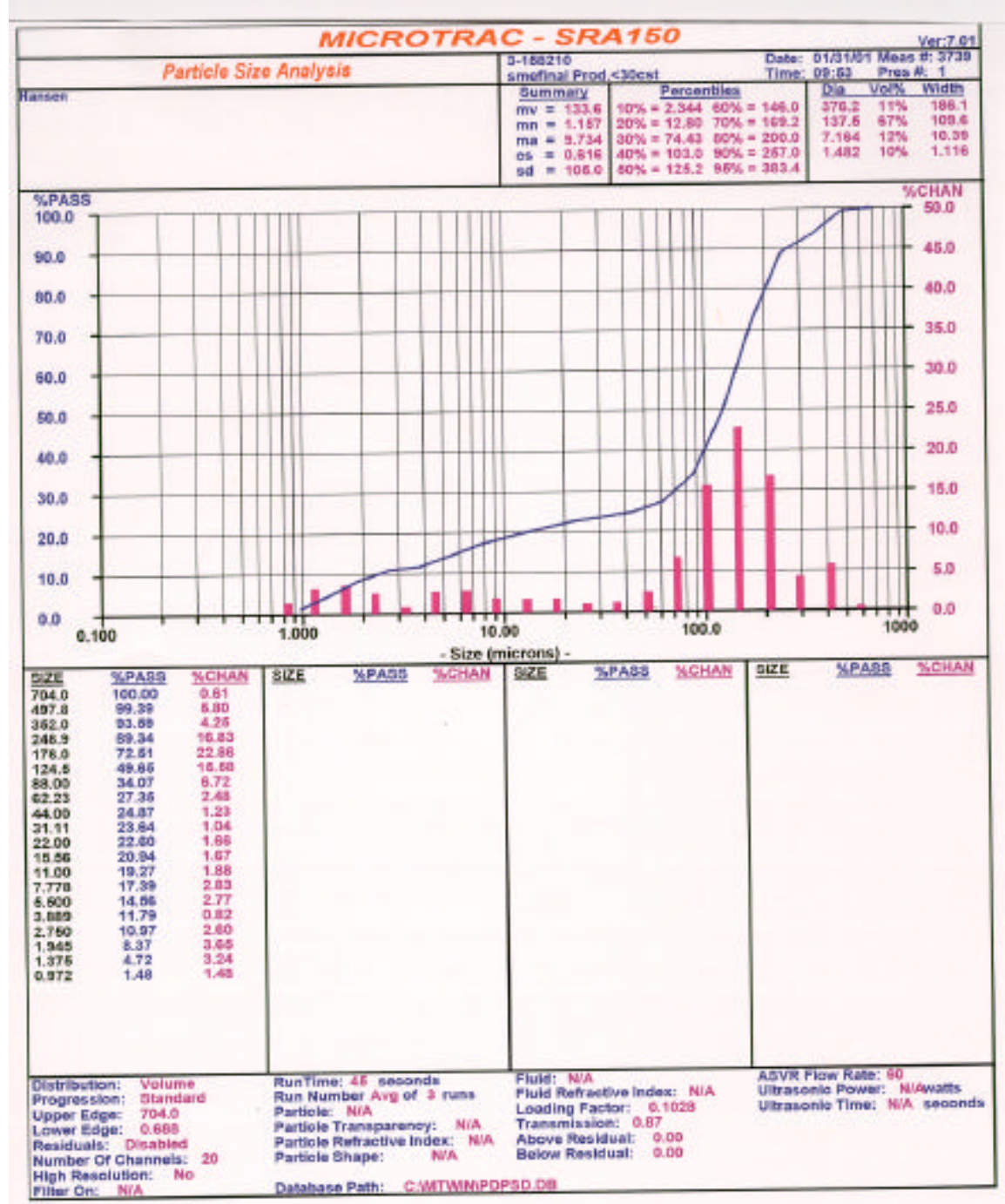

FIGURE A - 45: Particle Size Distribution < $30 \mu \mathrm{m}$ CST-Sludge-Frit \#2

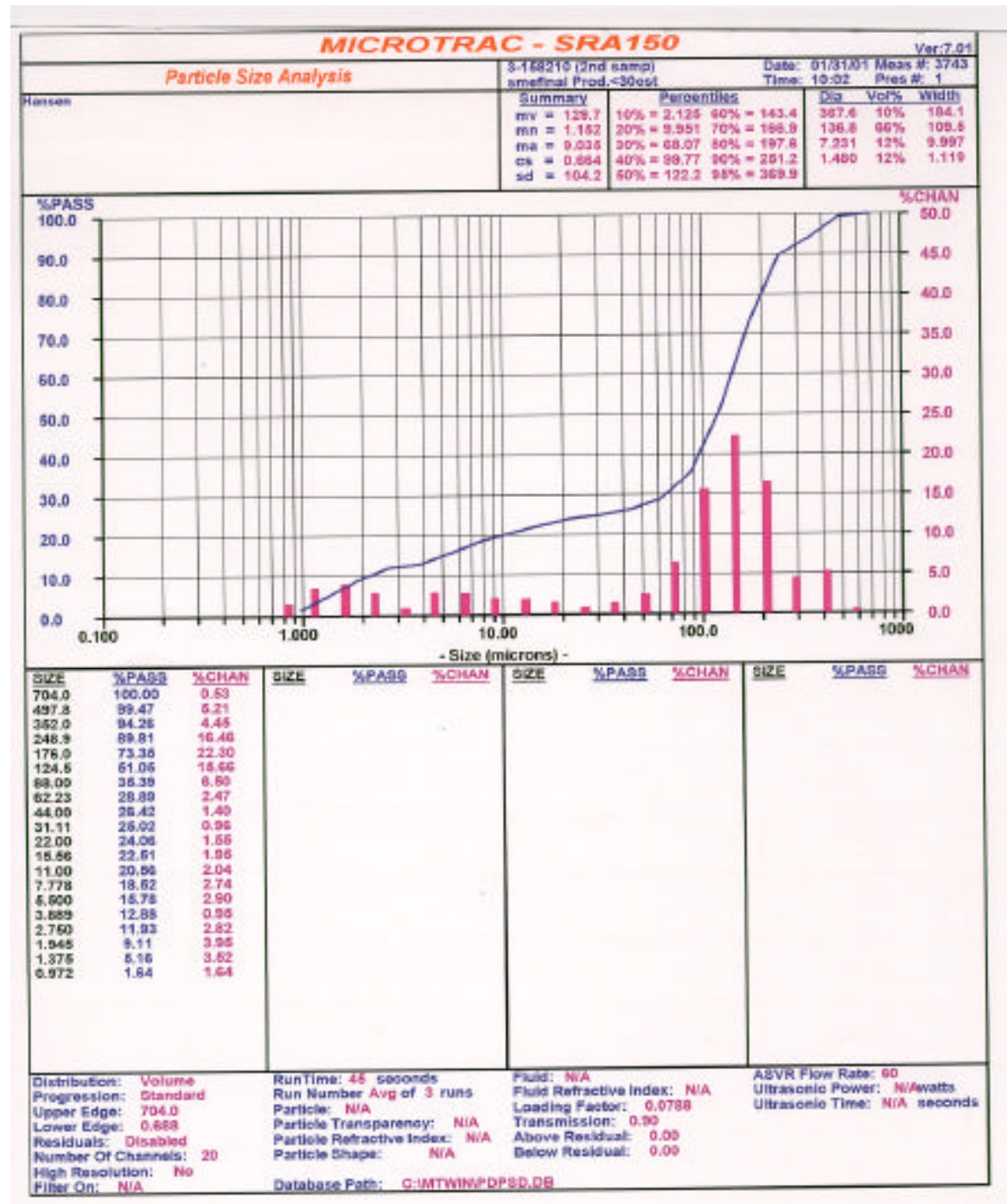




\section{TABLE A - 1: Analytical Results - ICP-ES}

SRTC Mobile Laboratory

Customer: Erich Hansen

\section{Date: $02 / 08 / 01$}

Preparation: LiB

Samples: Tk8/40 Blend, Tk8/40 Nominal, SME Final L30 CST

Preparation: $\mathrm{LiBO} 2$ and $\mathrm{Na} 2 \mathrm{O} 2$ prepartions

Note: Samples run in duplicate

\begin{tabular}{|c|c|c|c|c|c|c|c|c|c|c|c|c|c|c|c|c|c|c|c|}
\hline & \multicolumn{19}{|c|}{ Elemental Wt\% - vitrified at $1100 \mathrm{C}$} \\
\hline & $\mathrm{Al}$ & B & $\mathrm{Fe}$ & $\mathrm{Li}$ & $\mathrm{Si}$ & $\mathrm{Na}$ & $\mathrm{Ba}$ & $\mathrm{Ca}$ & $\mathrm{Cr}$ & $\mathrm{Cu}$ & $\mathrm{K}$ & $\mathrm{Mg}$ & $\mathrm{Mn}$ & $\mathrm{Nb}$ & $\mathrm{Ni}$ & $\mathrm{Ti}$ & $\mathrm{Zn}$ & $\mathrm{Zr}$ & \\
\hline $\begin{array}{l}\text { TK 8/40 Blend L177 CST } \\
(\mathrm{A})\end{array}$ & 2.82 & 2.15 & 8.36 & 1.34 & 22.7 & 7.85 & 0.078 & 0.887 & 0.150 & 0.038 & 0.094 & 0.955 & 0.626 & 1.57 & 0.425 & 2.23 & 0.105 & 1.52 & \\
\hline $\begin{array}{l}\text { TK 8/40 Blend L177 CST } \\
\text { (B) }\end{array}$ & 2.85 & 2.19 & 8.45 & 1.44 & 22.6 & 7.85 & 0.080 & 0.889 & 0.232 & 0.032 & 0.097 & 0.966 & 0.628 & 1.59 & 0.428 & 2.26 & 0.105 & 1.55 & \\
\hline Tk 8/40 Nominal (A) & 2.92 & 2.70 & 8.64 & 1.70 & 26.1 & 8.32 & 0.083 & 0.900 & 0.096 & 0.016 & 0.099 & 1.09 & 0.627 & 0.021 & 0.432 & 0.020 & 0.108 & 0.238 & \\
\hline Tk 8/40 Nominal (B) & 2.94 & 2.68 & 8.78 & 1.72 & 25.8 & 8.40 & 0.084 & 0.904 & 0.094 & 0.015 & 0.102 & 1.12 & 0.635 & 0.017 & 0.439 & 0.019 & 0.110 & 0.229 & \\
\hline SME Final 130 CST (A) & 3.03 & 2.34 & 9.13 & 1.51 & 23.4 & 8.28 & 0.084 & 0.932 & 0.085 & 0.020 & 0.095 & 1.01 & 0.667 & 1.16 & 0.456 & 1.55 & 0.113 & 1.16 & \\
\hline \multirow[t]{3}{*}{ SME Final 130 CST (B) } & 2.99 & 2.29 & 9.27 & 1.50 & 23.1 & 8.04 & 0.083 & 0.965 & 0.166 & 0.023 & 0.101 & 0.988 & 0.659 & 1.07 & 0.451 & 1.56 & 0.111 & 1.13 & \\
\hline & \multicolumn{19}{|c|}{ Oxided Wt\% - vitrified at $1100 \mathrm{C}$} \\
\hline & $\mathrm{Al}_{2} \mathrm{O}_{3}$ & $\mathrm{~B}_{2} \mathrm{O}_{3}$ & $\mathrm{Fe}_{2} \mathrm{O}_{3}$ & $\mathrm{Li}_{2} \mathrm{O}$ & $\mathrm{SiO}_{2}$ & $\mathrm{Na}_{2} \mathrm{O}$ & $\mathrm{BaO}$ & $\mathrm{CaO}$ & $\mathrm{Cr}_{2} \mathrm{O}_{3}$ & $\mathrm{Cu}_{2} \mathrm{O}$ & $\mathrm{K}_{2} \mathrm{O}$ & $\mathrm{MgO}$ & $\mathrm{MnO}$ & $\mathrm{Nb}_{2} \mathrm{O}_{3}$ & $\mathrm{NiO}$ & $\mathrm{TiO}_{2}$ & $\mathrm{ZnO}$ & $\mathrm{ZrO}_{2}$ & Totals \\
\hline $\begin{array}{l}\text { TK 8/40 Blend L177 CST } \\
\text { (A) }\end{array}$ & 5.33 & 9.08 & 12.0 & 2.88 & 48.6 & 10.6 & 0.087 & 1.24 & 0.219 & 0.043 & 0.113 & 1.59 & 0.808 & 2.25 & 0.540 & 3.92 & 0.130 & 2.05 & 101 \\
\hline $\begin{array}{l}\text { TK 8/40 Blend L177 CST } \\
\text { (B) }\end{array}$ & 5.39 & 9.18 & 12.1 & 3.10 & 48.4 & 10.6 & 0.090 & 1.24 & 0.339 & 0.036 & 0.116 & 1.60 & 0.810 & 2.27 & 0.544 & 3.98 & 0.130 & 2.09 & 102 \\
\hline Tk 8/40 Nominal (A) & 5.52 & 9.40 & 12.4 & 3.65 & 55.9 & 11.2 & 0.093 & 1.26 & 0.141 & 0.018 & 0.118 & 1.81 & 0.809 & 0.029 & 0.549 & 0.036 & 0.134 & 0.321 & 103 \\
\hline Tk 8/40 Nominal (B) & 5.56 & 9.47 & 12.6 & 3.70 & 55.2 & 11.3 & 0.094 & 1.27 & 0.137 & 0.016 & 0.122 & 1.86 & 0.819 & 0.025 & 0.558 & 0.034 & 0.136 & 0.309 & 103 \\
\hline SME Final 130 CST (A) & 5.73 & 9.76 & \begin{tabular}{|l|} 
\\
\end{tabular} & 3.24 & 50.1 & 11.2 & 0.094 & 1.30 & 0.124 & 0.023 & 0.114 & 1.68 & 0.860 & 1.66 & 0.579 & 2.73 & 0.140 & 1.57 & 104 \\
\hline \multirow[t]{2}{*}{ SME Final 130 CST (B) } & 5.65 & 9.63 & 13.3 & 3.22 & 49.4 & 10.9 & 0.093 & 1.35 & 0.242 & 0.026 & 0.121 & 1.64 & 0.850 & 1.53 & 0.573 & 2.75 & 0.138 & 1.53 & 103 \\
\hline & \multicolumn{2}{|c|}{ \% Total Solids } & \multicolumn{2}{|c|}{ \% Vitrified } & & & & & & & & & & & & & & & \\
\hline TK 8/40 Blend L177 CST & \multicolumn{2}{|c|}{52.6} & \multicolumn{2}{|c|}{47.7} & & & & & & & & & & & & & & & \\
\hline Tk $8 / 40$ Nominal & \multicolumn{2}{|c|}{52.5} & \multirow{2}{*}{\multicolumn{2}{|c|}{$\frac{47.9}{44.6}$}} & & & & & & & & & & & & & & & \\
\hline SME Final 130 CST & \multicolumn{2}{|c|}{49.2} & & & & & & & & & & & & & & & & & \\
\hline
\end{tabular}




\section{DISTRIBUTION}

M. J. Barnes, 773-A

S. B. Beck, 704-1N

D. W. Blankenship, 773-41A

J. T. Carter, 704-3N

N. F. Chapman, 210-S

Jack Collins, ORNL

D. A. Crowley, 773-43A

R. E. Edwards, 704-25S

H. H. Elder, 704-196N

S. D. Fink, 773-A

F. F. Fondeur, 773-A

J. R. Fowler, 704-196N

T. Hang, 773-43A

D. C. Hannah, 703-46A

E. K. Hansen, 704-1T

H. D. Harmon, 704-3N

R. N. Hinds, 704-3N

D. T. Hobbs, 773-A

E. W. Holtzscheiter, 773-A

W. M. Howell, 704-196N

R. A. Jacobs, 704-3N

R. T. Jones, 704-3N

Tim Kent, ORNL

Leon Klatt, ORNL

D. C. Koopman, 704-1T

D. P. Lambert, 704-1T

B. L. Lewis, 703-H

T. J. Lex, 703-H

S. L. Marra, 704-1T

C. J. Martino, 773-A

J. W. McCullough, 704-3N

J. P. Morin, 703-H

B. A. Moyer, ORNL

L. M. Nelson, 773-43A

J. E. Occhipinti, 704-27S

L. N. Oji, 773-43A

L. M. Papouchado, 773-A

P. M. Patel, 704-27S

T. B. Peters, 773-24A

S. F. Piccolo, 703-H

J. A. Pike, 704-196N

M. R. Poirier, 773-42A

L. D. Prince, 773-41A
Z. H. Qureshi, 786-5A

C. T. Randall, 773-42A

J. Reynolds, 704-S

M. A. Rios-Armstrong, 704-27S

S. N. Schlahta, 704-3N

F. G. Smith, 773-42A

M. E. Smith, 773-43A

S. G. Subosits, 704-196N

R. H. Spires, 773-A

W. E. Stevens, 773-A

P. C. Suggs, 704-196N

G. A. Taylor, 704-196N

Paul Taylor, ORNL

W. L. Tamosaitis, 773-A

W. B. Van Pelt, 773-42A

D. D. Walker, 773-A

Joe Walker, ORNL

Dennis W. Wester, PNNL

T. L. White, 773-A

W. R. Wilmarth, 773-42A

J. E. Young, 773-A

STI, 703-43A (4 copies)

LWP Files c/o Cathy Canada, 773-A

ITP Files c/o Cathy Smalls, 241-147H 